Florida International University FIU Digital Commons

\title{
An Ethnographic Study of Sectarian Negotiations among Diaspora Jains in the USA
}

Venu Vrundavan Mehta

Florida International University, venumehta1982@gmail.com

DOI: $10.25148 /$ etd.FIDC001765

Follow this and additional works at: https://digitalcommons.fiu.edu/etd

Part of the Religion Commons

\section{Recommended Citation}

Mehta, Venu Vrundavan, "An Ethnographic Study of Sectarian Negotiations among Diaspora Jains in the USA" (2017). FIU Electronic Theses and Dissertations. 3204.

https://digitalcommons.fiu.edu/etd/3204 


\title{
FLORIDA INTERNATIONAL UNIVERSITY
}

Miami, Florida

\section{AN ETHNOGRAPHIC STUDY OF SECTARIAN NEGOTIATIONS AMONG \\ DIASPORA JAINS IN THE USA}

\author{
A thesis submitted in partial fulfillment of the \\ requirements for the degree of \\ MASTER OF ARTS \\ in \\ RELIGIOUS STUDIES \\ by \\ Venu Vrundavan Mehta
}


To: $\quad$ Dean John F. Stack

Steven J. Green School of International and Public Affairs

This thesis, written by Venu Vrundavan Mehta, and entitled An Ethnographic Study of Sectarian Negotiations among Diaspora Jains in the USA, having been approved in respect to style and intellectual content, is referred to you for judgment.

We have read this thesis and recommend that it be approved.

Albert Kafui Wuaku

$\begin{array}{r}\text { Albert Kafui Wuaku } \\ \hline \text { Iqbal Akhtar } \\ \hline \text { Steven M. Vose, Major Professor }\end{array}$

Date of Defense: March 29, 2017

This thesis of Venu Vrundavan Mehta is approved.

Dean John F. Stack

Steven J. Green School of International and Public Affairs

Andrés G. Gil

Vice President for Research and Economic Development and Dean of the University Graduate School

Florida International University, 2017 
(C) Copyright 2017 by Venu Vrundavan Mehta

All rights reserved. 


\section{DEDICATION}

For my Mā, Bā and Bāpujī. I dedicate this thesis to my mother Dr. Purnima Mehta; and my grandparents Tarulata and Vinay Mehta. Your love, blessings and dreams are my treasures. 


\section{ACKNOWLEDGMENTS}

I find immense pleasure in expressing gratitude to all who helped and encouraged me throughout my research work. I begin by thanking my thesis advisor and my major professor Dr. Steven Vose. It would be apt if I say this thesis would not have been possible without his motivation and directions. His guidance was an essential pillar throughout my research. I thank him for fostering in me the skills I needed to conduct this research. He allowed me to work independently but constantly navigated my research.

I respectfully thank Dr. Albert Kafui Wuaku, my thesis committee member, who identified this research for having the potential to be developed into my MA thesis. His keen guidance helped me unfold the themes and concepts my thesis has. He continuously helped me solve any problem I encountered during the entire process of my research. I also thank him for igniting my passion for ethnography, anthropology and diaspora studies. I learnt from Dr. Wuaku, the essential methods of academic study of religion as I progressed throughout my research.

My special thanks to Dr. Iqbal Akhtar, my thesis committee member who has always encouraged me to be academically driven and active. His continuous support and constructive thoughts have provided me the energy I required to for my research. His scholarly inputs on diasporic study helped formalize my thoughts and theories. I thank Prof. Nathan Katz who inspired me to pursue a second MA in the Religious Studies at Florida International University. His inspiration has opened a new academic world to me. I would also like to thank Latika and Rajiv Jain for the fellowship that gave me the opportunity to do this research. I am grateful to the local Jain community members for their support and motivation. 
This thesis is for them and because of them - I sincerely thank the Jain community members of the Jain Center of South Florida, Jain Society of Metropolitan Chicago, The Jain Society of Greater Phoenix and The Jain Center of America (New York) for allowing me to conduct research at the temples and interact with the community members. Their contribution to thesis is what I respect and consider as my treasure. I take this opportunity to thank Dr. Oren Stier for strengthening my methodologies during the course that I took with him; his teaching helped me to shape my thoughts in the research. I specially thank Dr. Erik Larson for providing the conducive environment to develop my academic skills throughout my graduation years at the department. His appreciations for my academic endeavors have kept me working to achieve higher goals. I thank the management of Charotar University and Science and Technology (CHARUSAT) for motivating me and granting me the study leave to pursue this degree.

I thank my mother Dr. Purnima Mehta, whose dream and vision for her daughter to study Jainism have embarked my path towards this thesis. Her support, patience and warmth have been my drive to live away from my home and get involved thoroughly in the academic life. I could not have done this research if she would not have nurtured me with enlightening directions as a mother and as my former professor. I cannot conclude without expressing my veneration to Padma Bhushan late Prof. Madhusudan. A. Dhaky, Fellow of the Asiatic Society of Mumbai (FASM), and Director (Emeritus) American Institute of Indian Studies (New Delhi/Gurgaon). His blessings are forever alive within me. 
ABSTRACT OF THE THESIS

\title{
AN ETHNOGRAPHIC STUDY OF SECTARIAN NEGOTIATIONS AMONG DIASPORA JAINS IN THE USA
}

\author{
by \\ Venu Vrundavan Mehta \\ Florida International University, 2017 \\ Miami, Florida

\section{Professor Steven M. Vose, Major Professor}

This thesis argued that the Jain community in the diasporic context of the USA has invented a new form of Jainism. Sectarian negotiations are the distinguishing marks of the diaspora Jain community and their invented form of Jainism. Based on ethnographic study that is, interviews and observations conducted at four different sites (Jain temples/communities) from June-August 2016, the thesis examined the sectarian negotiations among the diaspora Jain community in the USA and the invented Jain tradition that is resulting from these negotiations. The central questions of the research on which this thesis is based were: 1) what are the levels, processes and results of sectarian negotiations within the Jain diaspora community in the USA, and 2) what is the nature and characteristic of the new form of Jainism, the invented tradition; and how do Jains in the USA experience and use it. 


\section{TABLE OF CONTENTS}

CHAPTER

PAGE

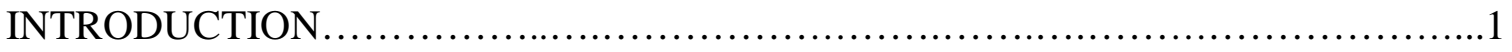

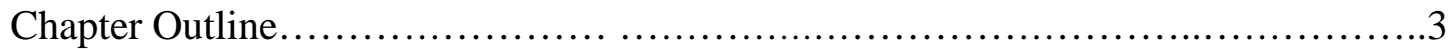

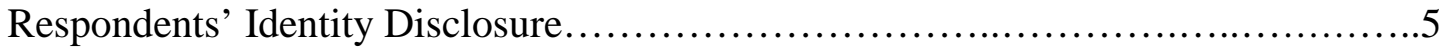

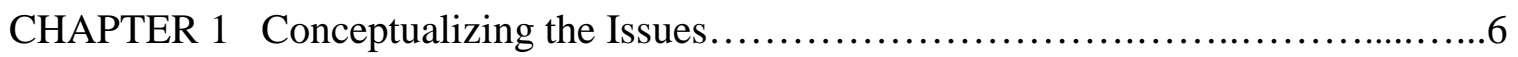

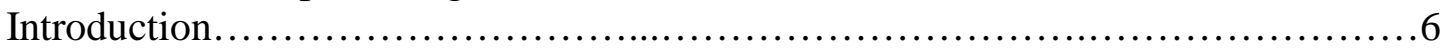

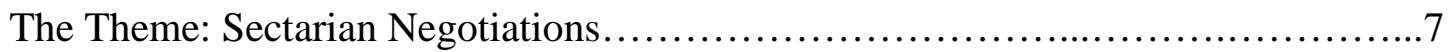

Model of the Sectarian Negotiations: Levels and Spectrums............................

Concept: Invented Tradition......................................................13

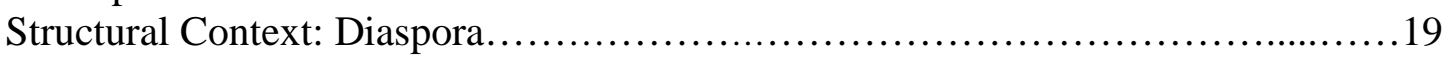

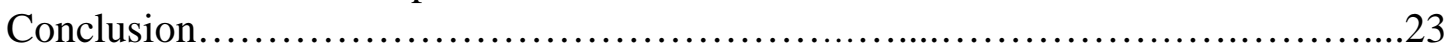

CHAPTER 2 The Story of My Fieldwork: The Methodical Considerations.................24

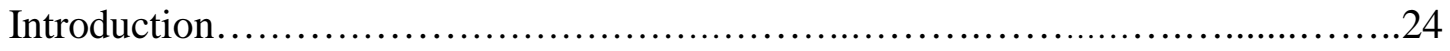

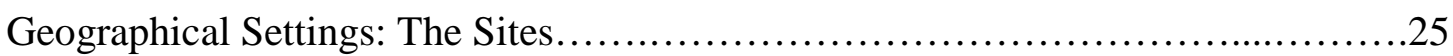

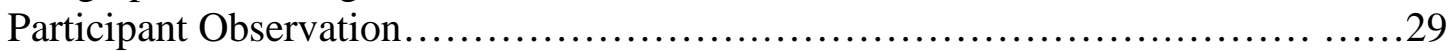

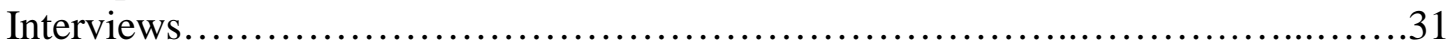

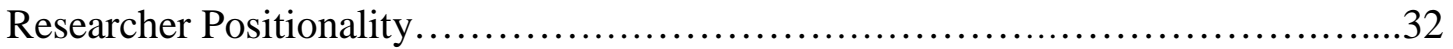

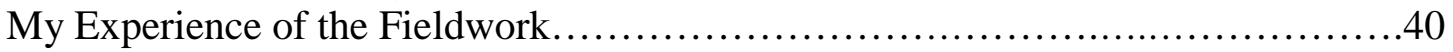

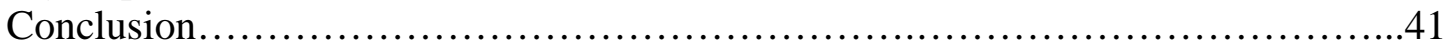

CHAPTER 3 Jainism, Sectarian Developments, a Contour of Jain Identity and the Diaspora Jains in the USA.......................................................42

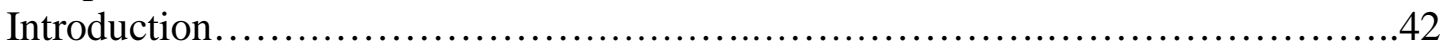

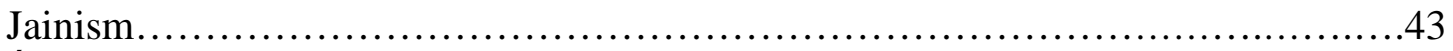

Śvetāmbara and Digambara: the Two Principle Sects in Jainism......................47

Sub-Sectarian Developments in Jainism..........................................58

Jains: Sectarian and other Identity Markers..................................62

Jain identity in India and its Significance to the Diaspora Jains in the USA..............65

Jainism's Status as Minority Religion...............................................67

Jains in Diaspora, a Special Reference to the USA.....................................69

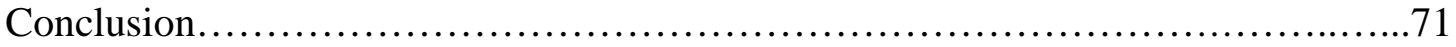

CHAPTER 4 Coming Together: the Inception and Development of the Sectarian

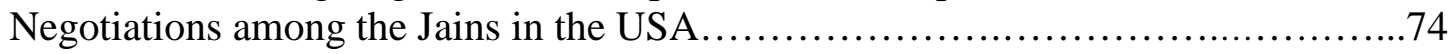

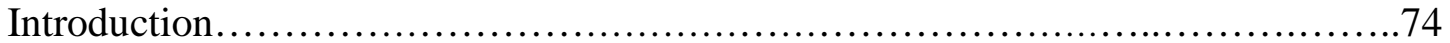

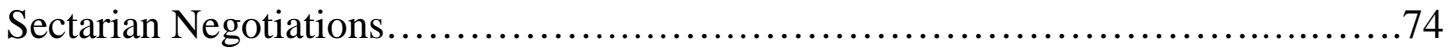

I Feel Stronger, United; I Feel Pride: Coming Together - the Creation

of the Sectarian Negotiations........................................................76

We are Jains: in the Making of a (common) Jain Identity in the USA.....................85 
The Śvetāmbaras cook for the Digambaras: Living and Working towards the Negotiations.................................................................97

Management and Decision-Making...........................................101

Conclusion.........................................................................

CHAPTER 5 Place-Making, Ritual-Visual Culture: The Invented Tradition...........112

Introduction............................................................... 112

Place-Making and the Jain Centers (temples): the Footing towards the Invented Tradition..................................................................113

The Jain Temples in the USA and the Visual Culture: A Shift from Traditional to Invention of Tradition......................................................116

I do all kinds of Pūjās: The invention of a Ritual Culture..........................136

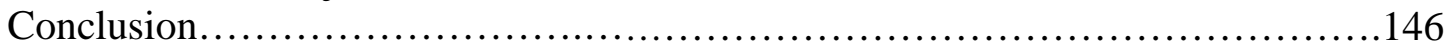

CHAPTER 6 Doctrinal-Philosophical Accordance and Invention of new form

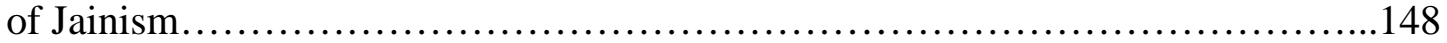

Introduction.............................................................. 148

The Sectarian Negotiations: the Need and Motivation towards Doctrinal

Philosophical Accordance....................................................149

Anekāntavāda, the USA Diaspora Jains’ Approach towards

Doctrinal-Philosophical Accordance.........................................154

Pāṭhaśālā: the USA Diaspora Jains’ Method towards Managing and

Merging the Doctrinal-Philosophical Variances................................ 158

Invention of new form of Jainism: Mahāvīra never said he was a

Śvetāmbara or a Digambara...

Pizza Effect: the USA Diaspora Jains’ Aspiration to Re-import the

Invented form of Jainism to India............................................. 175

Conclusion............................................................... 176

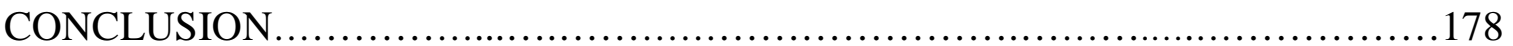

REFERENCES...........................................................181 


\section{LIST OF FIGURES}

FIGURE

PAGE

1. The levels and spectrums of the sectarian negotiations............................................

2. The Jain Center of South Florida..........................................................................26

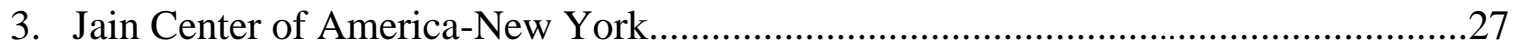

4. The Jain Society of Metropolitan Chicago.............................................................28

5. The Jain Center of Greater Phoenix.....................................................................29

6. The Jain community members attending a lecture by Samaṇi Shukla Pragya at Jain Center of South Florida...............................................................

7. Children enjoying being at the Jain temple building, Jain Society of Metropolitan Chicago.

8. Alpa Shah, a Jain community member at the Jain temple, Phoenix and Myself.

9. Interviewing Jain lay community members at Jain Center of South Florida.

10. Some of the Jain community members who I interviewed at the Jain Temple, New York

11. Jain community members at the Jain Center of Greater Phoenix.

12. The Digambara Jain worshippers performing the pūjā at the Jain Center of America.

13. Lay women form the Śvetāmbara sect in front of the kitchen while cooking for the Digambara Jain worshippers at the Jain Center of America.

14. The management committee members, Jain Center of South Florida.

15. An interview session with some of the management committee members, Jain Center of Metropolitan Chicago.

16. The Śvetāmbara and the Digambara images of Tīrthankaras as mūl nāyaks in the main garbha griha of the temple, Jain Center of South Florida. 
17. Śatruñjaya Tìrtha (right in the picture) at one of the walls at the temple, Jain Center of South Florida.

18. Bhaktāmara Ślokas, N̦amōkāra Mantra and Ātmasiddhi at the temple, Jain Center of South Florida.

19. A full-size picture of Śrimad Rājcandra at the temple, Jain Center of South Florida.

20. Images of all the five major Jaina sects at a common platform on Mahāvīra Jayantī (Mahāvīra's birthday), Jain Center of South Florida

21. The Śvetāmbara, the Digambara images of Tîrthankaras and Namōkāra Mantra as mūl nāyaks in the garbha griha, Jain Center of Greater Phoenix.

22. The Ahimsā Stambh (a peace-column) Jain Center of Greater Phoenix

23. The Jaina symbol - aphorism, parasparopagraho jivanam at Jain Center of Greater Phoenix.

24. Meditation Hall with the visuals of prominent spiritual teachers and ascetics of different Jain sects at Jain Center of Greater Phoenix.

25. Two images of Tīrthankaras (the Śvetāmbara and the Digambara versions) sitting at the side platform of the temple at Jain Society of Metropolitan Chicago. 128

26. Śrimad Rājcandra temple at Jain Society of Metropolitan Chicago .128

27. Posters about basic details of multi-sectarian canonical and non-canonical scriptures at the Jain Society of Metropolitan Chicago.

28. A bust-size image of Vīracand Gāndhī at Jain Society of Metropolitan Chicago.....129

29. A visual poster of the ascetics from all sects, Jain Center of America

30. Visual presentation of multi-sectarian Jain pilgrimage places, Jain Center of America

31. Visual presentation of Śrimad Rājcandra's life events, Jain Center of America .132

32. Information chart of the multi-sectarian temple building, Jain Center of America...133

33. A common ārti and the mangaldīvo performed on a Sunday by all the Jain 
community members together at Jain Center of South Florida.

.143

34. A common ārti and the mangaldīvo performed by all the Jain community members together at Jain Center of South Florida during Mahāvīra Jayantī celebration..........144

35. Satsang lecture attended by the Jain community members from all the sects at the Jain Center of America-New York.

36. Multi-sectarian rituals and worships performed at the same time at a common - shared temple by the Jains, Jain Society of Metropolitan Chicago........145

37. A common ārti performed by all the Jain community members together at Jain Center of Greater Phoenix

38. Young girls performing ārti in front of all the multi-sectarian images of the Tìrthankaras at the temple of the Jain Society of Metropolitan Chicago.... .146

39. An interview session with a Digamabar and a Śvetāmbar Jain community member at the Jain Center of South Florida.

40. A pāṭhaśālā class at the Jain Center of South Florida. .164

41. Pạthaśālā students explaining me the types of knowledge in Jainism at the Jain Center of South Florida.

42. A pāthaśālā teacher explaining the curriculum at the Jain Center of Greater Phoenix.

43. A pāthaśālā teacher, places multi-sectarian visuals to elaborate the importance of unity through teaching at pāthaśālā, Jain Society of Metropolitan Chicago........165

44. A common orientation session of all-level pāthaśālā classes at the Jain Society of Metropolitan Chicago, (I attended this class!).................................................166

45. Library section, pāṭhaśālā room at the Jain Center of America................................166

46. Library, Jain Society of Metropolitan Chicago.................................................167

47. Pāthaśālā building in the temple compound of the Jain Center of Greater. .167 


\section{INTRODUCTION}

What happens when you leave your homeland and make a new home in a foreign land? How does your religion impact the way you process your settlement as immigrants? How do you determine and re-shape your religion in a diaspora condition? I have read many classical and modern works on people in diaspora who re-establish their identities and bring out new concepts and themes in the process of shaping their religious identities to fit their new lives. I have always desired to study people and write about their life experiences. These interests shape the trajectory of my research about the Jain diaspora community in the USA. This ethnographic study presents accounts of the journeys of several communities of diaspora Jains in the USA.

Jainism, a religion rooted in India, had a sectarian split that also triggered various splits in the community by the end of the first century C.E. Since this time Jain traditions have undergone a number of schisms throughout their history. There is little intersectarian interaction among Jains in India today. Jain identities are further divided according to people's affiliation with one or another of several monastic lineages (gacchas) as well as geography and caste (jāti/jñäti). Sectarian splits also demonstrate that the divisions developed into various sociological sects and doctrinal schools in the Indian sub-continent (Jaini 2008 and Flügel 2006). With an escalation of modernity and globalization, many Jains began to migrate out of India, especially to the USA during mid-1960s. Today, the Jain diaspora community is a very small religious minority among other South Asian diasporas; approximately $140,000^{1}$ Jains live in North America.

\footnotetext{
${ }^{1}$ Estimated population figure according to the JAINA website. JAINA is the federation of Jain associations in North America.
} 
As the Jains settled in a foreign land, they also brought their identities - religious, sociocultural and lingual along with them.

In this study, I argue that the Jain diaspora in the USA has produced a new form of Jainism, through a series which I term "sectarian negotiations.” By sectarian negotiations I refer to the formation of common, formal Jain communities and the building of common Jain centers (temples) which all the sects share. The expression also refers to the designing of an inclusive hybrid ritual and visual culture, the organizing of pāthaśâlās (religious teaching programs), and the emergence of a common assent and accord for managing doctrinal and philosophical differences between the various sects of Jainism. I contend that that this new form of Jainism is a diasporic invention, because while the Jain community members in the USA view it as a legitimate form of Jainism and depend on it to meet their spiritual and social needs, it departs radically from what many Jains in India consider to be normative Jainism. My objectives of the research on which this thesis is based were: 1) to study and explore the levels, process and models of sectarian negotiations within Jain diaspora community in the USA, and 2) to study the nature and characteristics of the invention of tradition resulting from the sectarian negotiations among the Jain diaspora community in the USA.

The study argues that the conditions of their lives in the diaspora pushed Jain actors in the USA to create this new form of Jain practice. As a small Indian diasporic community, the Jain community has come to realize that sectarian divisions are a hindrance to its efforts to integrate as a unit. The sectarian negotiations then are intended to reorganize the sectarian barriers that typically divide various traditions of Jainism so that a united Jain community can be created in the USA. The invented Jain religious 
practices such as common Jain temples and hybrid ritual-visual culture have become the symbol of community integration and the focal point of place-making for Jain migrant communities in American cities. In the chapters that follow, I demonstrate the features of this new Jainism, and offer an analytical account of the forces that pushed its creation, how the Jains in the USA experience it, and the contexts of the Jain diasporic religious experience in which the Jain community members play out the sectarian negotiations.

My ethnographic study also features two major developments within the diaspora Jains in the USA. The research demonstrates that the Jain immigrants through the sectarian negotiations have created a common 'Jain' identity among the other Indian diasporas in the country of settlement. As my research further builds on the concept of invention of tradition, I demonstrate how the diaspora Jains in the USA have re-created a meaning of Jainism through the sectarian negotiations.

\section{Chapter Outline}

Chapter 1 provides the theoretical foundations upon which the study rests. The chapter informs about the three major aspects of my research: the sectarian negotiation as the major theme; 'invented' tradition as the key concept; and diaspora as the structural context of the former two. The chapter helps us to understand how I conceptualize the findings from my research, which I present in the rest of the chapters of this thesis. Chapter 2 sets up the platform for my ethnographic research of the Jain diaspora community in the USA. This chapter introduces the four Jain communities and the sites I studied. The chapter informs about the methods I used during my research. Moreover, the chapter gives accounts offer my positionality as a researcher. 
Chapter 3 presents a brief introduction of Jainism and the sectarian developments within the Jain tradition. The chapter provides details of the attitudes and characteristics of various sects in Jainism as well as other identity markers of the Jains. Since, the sectarian negotiations and the new form of Jainism are creations using the variations and differences among the Jain sects, this chapter offers, as a background, detailed descriptions that will enable us to understand the sects and sub-sects in Jainism. This chapter also discusses the nature of Jainism and the struggle with the question of Jain identity in India; sectarian disputes as they play out in spheres such as religion and community. This discussion is important as it offers us leads in understanding why the diaspora Jains' in the USA view the creation and performing of a common Jain identity to be crucial to their survival as a minority religious group. The chapter also offers a review of relevant literature on diaspora Jains in the USA. Chapter 4 discusses the social and religious contexts and needs of Jains in the USA, their coming together, and the reconfigurations of belief and practice they produced as responses to these needs. In this chapter, I examine the characteristics of the sectarian negotiations among the Jain diaspora communities and analyze the factors that initiate these negotiations. The chapter also demonstrates how the Jain community members perceive and experience the negotiations. In this chapter, I also examine a series of strategies the Jains adopt to manage and sustain the sectarian differences. I argue that the Jains, as a result of the negotiations, construct a common Jain identity in the land of settlement.

In Chapter 5, I examine the diaspora Jains' uses of the sectarian negotiations to produce and reproduce themselves anew. I show how the diaspora Jains have formed common formal Jain communities, using the invented Jainism as a place making strategy. 
I analyze how constructing common Jain temples and the creation of new visual and ritual cultures, which are aspects of the community’s creative innovations, are place making processes the Jain migrants use to root themselves in the USA. I argue in this chapter that by studying the ritual-visual culture as parts of new form of Jainism constructed by the diaspora Jains in the USA we understand how the tradition is an invention. I demonstrate how the sectarian unisons influence the invention of a new form of Jainism and vice a versa.

In Chapter 6, I demonstrate how the Jain diaspora community’ invents a new form of Jainism by deemphasizing, eliminating and re-organizing the sect specific doctrinal differences. I examine how the sectarian unity created as a result, motivates the Jains to identify the approaches and methods they can use to manage the accordance at the doctrinal level. I also argue in this chapter that synchronization at the doctrinal level and identification of requirements to maintain the sectarian negotiations are portions of the invented Jain tradition, that is, the new form of Jainism. The chapter emphasizes how the Jains in the USA have invented a new version of Jainism that compliments their needs of diaspora and sectarian unity. In this chapter I examine the attributes of this new form of Jainism.

\section{Respondents’ Identity Disclosure}

I have changed or replaced names of the respondents whose interviews and direct quotes I have used in this thesis. As many respondents had requested that I should not mention their caste, religious sect or age, I have kept their identity markers unmentioned or anonymous. 


\section{CHAPTER 1}

\section{Conceptualizing the Issues}

\section{Introduction}

In this introductory chapter, I lay the theoretical foundations upon which the study rests. The chapter offers an account of the themes that emerged from the data I gathered from the Jain communities and temples I studied and reflects on the concepts that help in establishing my arguments. I build on socio-anthropological frames, especially ideas from the sociology of religion, and on theories of diaspora. The first set of the conceptualization entails the discussion of the 'sectarian negotiations', as a major theme, and 'invented tradition’ as a prominent concept in analyzing these negotiations. It is also important to deliberate on some relevant theorizations of diaspora, as the diaspora is the structural context in which we can understand the experiences of the Jain community in the USA. I will present a broad view of how the structural context, the theme and the concept are linked, intertwined, and overlap. I will substantiate the conceptualizations offered in this chapter by presenting my observations, participants’ responses and findings in the chapters that follow.

When I began this study I had no specific theoretical concepts in mind. I had formulated objectives of the study and identified some general questions that would guide my field research. As I progressed with my interviewing of the members and gatekeepers of the Jain diaspora and my observations of the ethnographic details of the sites, I started to formulate more specific and contextual questions. A prominent theme, the sectarian negotiations and invention tradition, the major concept began to emerge as a result of the responses from the interviews and the observations I made during the 
fieldwork. This particular section indicates the main theme and reviews the concept that offers it a theoretical grounding.

\section{The Theme: Sectarian Negotiations}

My fieldwork at the four Jain centers (temples) made me aware of the sectarian diversity among the Jain diaspora in the USA. Aside the two major Jain sects, that is, the Śvetāmbara (white-clad) and the Digambara (sky-clad), other sub-sects, such as Sthānakavāsīs (non-image worshippers), Terāpanthīs (Path of Thirteen), Mūrtipūjakas (image worshippers), Kavi Panth (followers of Śrīmad Rājcandra) and Kānjī Panth (followers of Kānjī Svāmī) are present in the diaspora Jains in the USA. While the sectarian differences are the most observable, the diversity is also reflected in the broad range of members’ castes (jāti/jñāti), languages, cultural backgrounds, geographical affiliations, and monastic lineages (gacchas). As I progressed in my interviewing of the community members from different sects, and in observing the temples, one theme emerged continuously and very prominently. I refer to this theme as "sectarian negotiations.” The sectarian negotiations take place in the context of the formation of common formal Jain communities, the building of common Jain center (temple) which are shared by all the sects, the designing of an inclusive hybrid ritual and visual culture, the organizing of pạthaśālās (religious teaching programs), and the emergence of a common assent and accord for doctrinal and philosophical differences in Jainism.

\section{Model of the Sectarian Negotiations: Levels and Spectrums}

As I began to explore the theme elaborately and closely, I observed that the sectarian negotiations are active, functioning and implemented on the following levels and spectrums in all the four Jain communities and centers (temples) I studied. Moreover, the 
levels and spectrums are intertwined and overlapping; they affect one another reciprocally (see Figure 1).

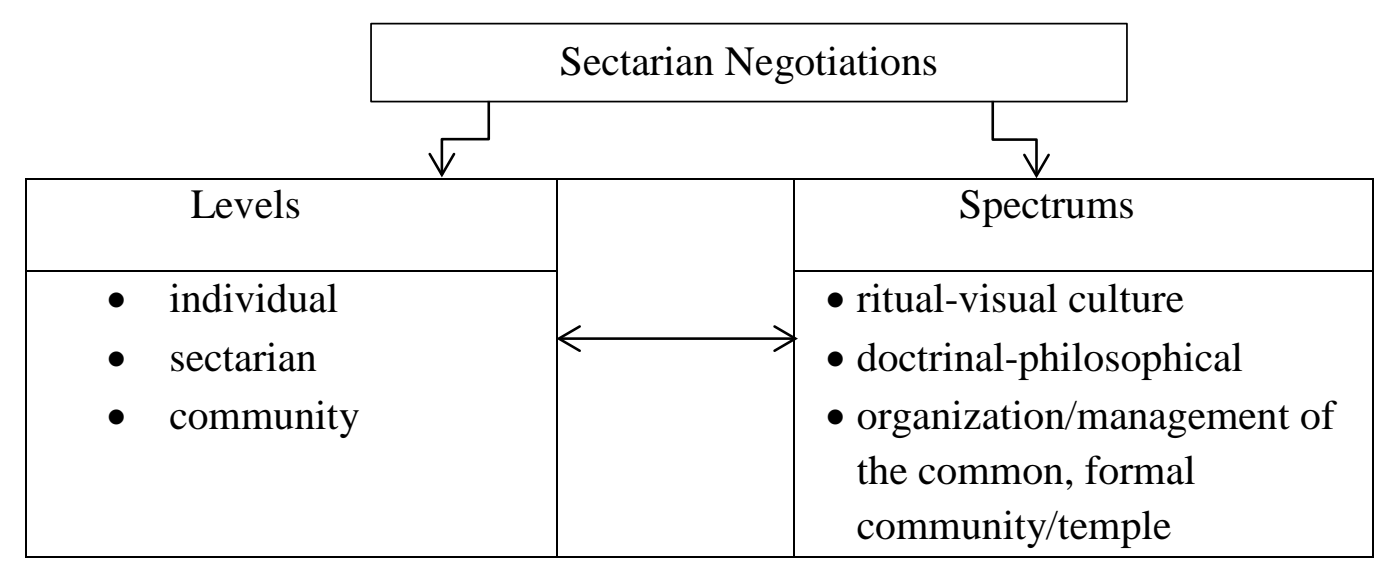

Figure 1. The levels and spectrums of the sectarian negotiations

I observed that the sectarian negotiations among the Jain diaspora community in the USA is not limited to the community's demonstration of interactions and the accommodations between various sects of Jainism, but extend to sub-sects, caste, language, cultural and geographical affiliations. This ethnographic study of the Jain diaspora community then is an exploration of the process of these negotiations and their result, that is, a new Jain religious form. The study emphasizes how the sectarian negotiations are becoming a unique feature of the Jain diaspora community in the USA.

In offering a theoretical way to understand the sectarian negotiations taking shape among the Jain diaspora I find it useful to build on Arjun Appadurai's (1996) reformulation of the meaning and usage of culture in our increasingly globalizing world. In his exploration of anthropological conditions in the era of globalization, Appadurai points to the need to link the process of naturalization and mobilization of group identity with globalization. Appadurai recasts culture as something that is “...not usefully 
regarded as a substance... but it better be regarded as the dimension of phenomena, a dimension that attends to situated and embodied difference” (1996: 12-13). He further adds that the word "culture” is close to the idea of "ethnicity," and suggests that we must regard the cultural as those differences that either give expression to, or prepare the groundwork needed for the mobilization of, group identities. In this context, Appadurai equates culture with ethnicity and makes it a basis for creating and performing group identity. Furthermore, Appadurai notes that, in our usage of culture we should not stress simply the possession of certain qualities (material, linguistic or territorial). Rather what we should emphasize is how 'the consciousness of these attributes and their naturalization’ are essential to group identity (1996: 13). Further, Appadurai links these qualities to the contemporary era of migration or succession and globalization (1996: 1516). Appadurai's argument offers crucial leads in our theoretical exploration of the process of sectarian negotiation among the Jains in the USA. Following Appadurai, I suggest in this study that we view the Jain diaspora in the USA as a distinct Indian ethnicity, with the Jain religion functioning as the basis of the difference of this ethnic group from other Indian diaspora communities. I argue that for the diaspora Jains in the USA, Jainism is the basis of a Jain culture which encompasses various attributes and differences. Appadurai’s (1996) adjectival use of ‘culture’ speaks to the Jain diaspora community’s approach to 'Jainism.' The diaspora Jains views Jainism as a process (not a thing) that is subject to periodic revisions and themselves as active agents in this revision. I use Appadurai’s assertions on culture and ethnicity especially in chapters 4 and 6 to examine the sectarian negotiations as the processes of naturalization and mobilization among the Jains to form a common identity and to create a new form of Jainism. 
The dismantling of sectarian barriers implicit in these sectarian negotiations is part of a larger project aimed at using a common Jain religious form for the mobilization of the Jain diaspora group identity in the USA. In chapter 4, I will show how the Jain community reinforces their sense of distinctiveness, pushing it to embark on sectarian negotiations within it. The community sees the dissolution of sectarian barriers as a way of consolidating the foundation of its ethnicity. Also, I argue that the Jain diaspora community's processes of sectarian negotiations exemplify the migrations, succession and other globalization processes that Appadurai (1996) writes about. The context of this process, the USA, is an epicenter of globalization. I will demonstrate the link between migrations, the recognition of differences and the sectarian negotiations within the Jain diaspora in the USA in chapters 4, 5 and 6.

I argue in chapters 4 and 5 that the sectarian negotiations significantly impute to Jainism a kind of "culturalism” (Appadurai 1996: 15). Appadurai defines culturalism as, "a feature of movement involving identities consciously in making” (ibid); it is frequently associated with extraterritorial histories and almost always with struggles for stronger recognition from existing nation-state or from various transnational bodies (Appadurai 1996). Referencing the concept of culturalism, I ague that for the Jain diaspora community in the USA, the sectarian negotiation represents an ascertained effort of culturalism. Chapters 4, 5 and 6 demonstrate the process of the sectarian negotiations among the Jain diaspora community in the USA as a culturalist movement. I argue in chapter 4 that the sectarian negotiations entail the creation of a common Jain identity in the USA. My study reveals how the process of the sectarian negotiations among the Jain diaspora in the land of settlement is associated with a struggle for stronger recognition 
from the existing nation-state, the USA, and also from various transnational bodies such as India and other countries from which the Jains migrated to the USA. Chapters 4 and 5 in my thesis will show that the sectarian negotiations, as processes of culturalism, are based on two major premises: first, to form a separate "Jain identity” amongst Indian diasporas, and second, to be recognized as a 'religious minority identity' in the USA. Sociologists examine the dynamics of social phenomena with the 'social movement' paradigm and contribute to understandings of what is peculiar to those forms of group behavior (Banks 1972). Rudolf Heberle (1951) defines ‘social movement' as:

A specific kind of concerted-action groups; they last longer and are more integrated than mobs, masses and crowds, and yet are not organized like political clubs and other associations...Group consciousness, that it, a sense of belonging and of solidarity among members of a group, is essential for a social movement, although empirically it occurs in various degrees (439).

Similarly, Banks (1972) mentions and describes how we conventionally regard social movements as part of the subject matter of collective behavior, but can also view them as an aspect of social change. Banks identifies some social movements as 'socially constructive', and differentiates them from the movements that are social responses to situations of stress. He identifies social innovation and invention of social technologies as features of such social movement. For Banks, social movements are resourced by collective behavior, are those processes that invent social technologies, and are regarded as the agents of social change. I argue in chapter 4 that the sectarian negotiations among the Jain diaspora community represent a kind of social movement within the broader Jain community. This is to say that the diaspora Jains have collectively invented their social technologies in a form of the sectarian negotiations, to distinguish themselves from the Jain communities in India, where rigid sectarian boundaries are maintained. The sectarian 
negotiations as I will demonstrate in chapters 4, 5 and 6 entail social innovations and the invention of social technologies such as methods of integration and mutual support. This form of social movement leads to the creation of a new form of Jainism. I show in chapter 6 how the sectarian negotiations among the Jain diaspora community which results in 'invented Jain traditions' emphasize the experiences and perceptions of the Jains in diasporic conditions, not what is considered to be traditional Jain practice. This demonstrates the agency Jain actors in the American diaspora feel they have to lead reforms within the tradition as a whole. It is, however, still not clear how these diasporic changes are affecting Jain religious practice in India.

I approach the sectarian negotiations as diasporic phenomena among the Jain community in the USA from a sociology of religion perspective and take support from James A. Beckford's (2003) social constructionist approach and Steve Burce’s (1999) rational choice theory to demonstrate the Jains diaspora community members' roles as active agents in this project. Especially in chapters 4 and 6, I offer an account of the strategies (modes, methods) adopted by the community members in their sectarian negotiations, and how they rationalize these strategies. I will offer a discussion of a broad range of factors the Jains mention as important in their decision making processes in the course of the sectarian negations in chapter 4 for the processes of coming together; creation of common place of worship (along with ritual-visual culture) in chapter 5; and creating a new form of Jainism as a result of accordance at doctrinal level in chapter 6 of this study. I will also discuss the perceptions and experiences of the Jain diaspora community and its conscious and effortful process of the sectarian negotiations in the chapters of the study. 


\section{Concept: Invented Tradition}

I now turn my attention to another important theoretical concept this study builds on, that is, the 'invention of tradition’ (Hobsbawm 1983). The study examines the new form of Jainism, invented by the Jains in the in North America as a result of the sectarian negotiations among them. The invention of tradition will be examined and analyzed in chapter 5 and chapter 6 to offer a coherent whole body of frameworks for demonstrating the attributes of the new form of Jainism in the USA.

The concept of invented tradition has been the focus of studies and interest for historians of the past two centuries. In this study, I draw mainly on the concept as it is defined and explored by Eric Hobsbawm (1983). He defines an “invented tradition” as:

A set of practices, normally governed by overtly and tacitly accepted rules and of a ritual or symbolic nature, which seeks to inculcate certain values and norms of behavior by repetition, which automatically implies continuity with the past. In fact, where possible, they normally attempt to establish continuity with a suitable historic past (1).

The notion of invented tradition connotes revolutions and 'progressive movements' intended to forge links with the past. Inventing traditions represent responses to novel situations even though the inventions can take the form of references to old situations. 'Traditions' in this sense cannot be equated with 'customs.' Hobsbawm illustrates the distinction between the 'customs' and 'tradition' in the following words: “'Customs' is what judges do; 'tradition' (in this instance, invented tradition) is the wig, robe and other formal paraphernalia and ritualized practices surrounding their substantial action” (1983: 2-3). The distinction here suggests that the decline of 'custom' certainly changes the 'tradition' with which it is habitually interwoven. It can be argued here that ‘invented tradition’ is more of a pragmatic phenomenon that deals with things sensibly 
and realistically, and not just based on theoretical considerations. Inventions are motivated by practical considerations. Hobsbawm says it is a process imposed by repetition. He also defines invented tradition essentially as a process of formalization and ritualization, characterized by reference to the past (Hobsbawm 1983: 4).

Intended to meet the demand and supply side of the rapid and sufficient changes, 'invention’ of tradition entail the acquiring of ancient materials to form a novel tradition. From this point of view, the traditions invented are constructed from using old material but are modified, ritualized and institutionalized for the new purposes. I argue in chapters 5 and 6 that the new form of Jainism invented by the Jain community in the USA reflects pragmatic adaptations to novel diasporic situations. This means, the new form of Jainism created by the Jains at the spectrums of visual-ritual cultures and doctrinal and philosophical draws out the religious materials from Jainism but the materials are recreated, re-organized, and altered to meet the emerging needs of a diasporic community. I will demonstrate in chapters 5 and 6 how creating a new form of Jainism in the USA involves reconfiguring forms of ritual-visual cultures, assimilation of sectarian philosophies and doctrines, and invention of hybrid religious beliefs and practices. Invented tradition is premised upon the inapplicability of the old tradition with the social surroundings and changes. According to Hobsbawm 'invention' of tradition is expected to occur more frequently when a rapid transformation of society weakens or destroys the social pattern for which 'old' traditions had been designed, producing new ones to which they were not applicable, or when such old traditions and their institutional carriers and promulgators no longer prove sufficiently adaptable and flexible, or are otherwise eliminated (1983:4). I argue that inception and formalization of a new form of 
Jainism is a response to and the diasporic conditions and surroundings. Specifically, the Jain community, being a religious minority in the USA recognizes a need to re-configure and manage sectarian barriers that divide the community so that it can generate a common and collective sense of identity among Jains. The sectarian negotiations entail combinations of various sectarian features, called for as replacements of the 'old' and the creation of a whole new set of Jain religious attributions to meet the needs of the diaspora.

Hobsbawm distinguishes among three types of invented traditions and suggests that each has a distinctive function: a) those establishing or symbolizing social cohesion and collective or the membership of groups, real or artificial communities, b) those establishing or legitimizing institutions, status or relations of authority, and c) those whose main purpose is socialization, the inculcation of beliefs, value systems and convention of behavior (1983:9). The study shows that the Jainism invented by the Jain diaspora community in the USA indicates all these three distinctive types of invented tradition. I examine explicitly in chapter 4 that the sectarian negotiations act as the cause towards generating social cohesion and collective membership among the Jain communities. Chapters 5 and 6 discuss constructing of temples shared by all the sects of Jainism and inculcation of new form of Jainism as collective belief, value and behavior among the Jains in the USA. Specifically, the new form of Jainism is helping to establish social cohesion, socialization and collective or the membership of groups. It generates a context for establishing and legitimatizing common Jain centers, and it facilitates the inculcation of common Jain beliefs, value systems and conventions of behavior. 
The invented Jainism has a reciprocal relationship with the sectarian negotiations. This means, the presence of a new form of Jainism is corresponding to the smooth functioning of the sectarian negotiations. I argue that invented tradition is central to the successful implementation of the sectarian negotiations among the Jain diaspora in the USA. It unites the community members in the diasporic context.

It is important to discuss how 'meaning' in the context of changes is considered an important element of the notion of 'invented traditions. The 'meaning' of traditions invented is different from the meaning of those symbols and rituals used in a tradition. Cannadine (1983) argues that in order to rediscover the 'meaning' of the 'Invented' tradition, it must be interpreted in the context of the relationship of the specific social, political, economical and cultural settings within which it is performed (1983:105). According to his argument, repeated rituals can remain unaltered over time, but their 'meaning' may change profoundly depending on the nature of the context (ibid). Using the example of English coronation rituals to illustrate, Cannadine writes:

While the basic text of a repeated ritual may remain essentially unaltered- such as the crowing, anointing and recognition of an English coronation - the precise manner in which the ceremony is produced may differ, which in itself only serves to give a further dimension to changes in 'meaning' (1983:106).

This suggests that the nature of the 'invented traditions' also considers the manner of procedure, nature of performance and context as important factors. Thus, even though rituals remain unaltered, the conditions like the context, settings, manner, and nature of performance make them "inventions.”

Cannadine offers important analytical leads in this study. In chapter 5, the discussion will show how the new form of Jainism demonstrates exceptional attributes of 
innovations in terms of context, settings, manner, and nature of performances at the spectrums of ritual and visual cultures. Such innovations are exemplified by the designs of common temples, architectural arrangements, ritual performances, annual festivals and religious schools as well as the philosophical and doctrinal aspects of Jainism that are emphasized and engaged. Moreover, I argue in chapter 6 that the changes in the context, settings, manners and nature of performance have impacted the diaspora Jains' perceptions of Jainism. In other words the Jains in the USA have re-organized and invented a new ‘meaning' of Jainism.

Globalization and religion highlight complex historical and contemporary interactions. This study is about the inventing of a Jain religious tradition by Jain diaspora community in the USA, a setting that is highly multicultural and globalized. In the present age of increasing globalization, religious spaces, places and maps are considered the key components through which individuals and institutions try to locate themselves in the new landscape as they respond to dislocations generated by globalization (Vasquez and Marquardt 2003: 52). Following this perspective I show in chapter 5 how the new form of Jainism, that is, the "invented tradition," is also playing a key role in place-making processes in the Jain diaspora of the USA.

This study expands on the conversation on place making by exploring the Jain community's 'place-making' in the USA. Vasquez and Marquardt assert that "religion is a key cultural component in the construction of both new spatio-temporal arrangements and emerging cognitive maps through which individuals and institutions try to locate themselves in the new landscape generated by globalization” (2003: 52). I argue in chapter 5 that formal and common Jain centers (temples) are creatively organized spaces 
for place-making, through which, Jains create a common social and religious community in the USA. This study reveals that religion is playing an important role in the process of a common place-making that is helping the Jain diaspora community to experience a common Jain identity.

Moreover, the place-making exercise for the Jain diaspora is not just limited to the connectedness of the Jains' social worlds, but it has precipitated the 'invented tradition', a new form of Jainism. I argue that place-making, in the form of building common religious centers plays out its role in extending the negotiations. I demonstrate in chapters 5 and 6 that the place-making for the Jain diaspora has advanced into creating a new form of Jainism that includes designing an inclusive, hybrid ritual and visual culture; organizing pạthaśālās (religious teaching programs); and reaching toward a common assent and accord for doctrinal and philosophical differences in Jainism. In chapters 5 and 6, I discuss and analyze the processes of place-making and its implications for the creation of the 'invented traditions.'

I approach invented traditions from the social constructionist approach. Beckford characterizes the use of the approach to study religion sociologically as "modest" social constructionism (2003: 3). This approach "tries to uncover how terms such as 'religion', 'religious', 'sacred' and 'spiritual' are used; how the usage varies across different categories of people, time and space; how it reflects collective interests; how human actors justify their usage of these terms; how social groups and organizations institutionalize the usage; and how social agencies try to regulate the activities to which the terms are applied" (Beckford 2003: 193). He emphasizes that the meaning of religion from a social constructionist approach lies in a continuous process of negotiations, 
reproduction and challenge the meanings attributed to religion are a product of social interactions and negotiations at the level of individual, group and organization. For Beckford, global forces are shaping what counts as religion, and this adds more to the discussion with regards to topics such as secularization, pluralism, globalization and religious movements (ibid.). Following Beckford, the study will demonstrate in chapter 6 the ways in which the Jains, as a diaspora community are constructing, communicating, and negotiating shared meanings of 'Jainism.'

The new form of Jainism described in the study consists of formations of common, formal Jain communities, and building common Jain centers (temples) which are shared by all the sects. It also entails designing an inclusive, hybrid ritual and visual culture; organizing pāthaśālās (religious teaching programs); and reaching toward a common assent and accord for doctrinal and philosophical differences in Jainism. I will explore and analyze the nature and specific features of each of these elements through the concepts of diversity in religion such as 'bricolage', 'syncretic' and 'hybrid' (Beckford 2003: 74-75).

\section{Structural Context: Diaspora}

'Diaspora' and 'religion' provide the structural context of my ethnographic study of the sectarian negotiations among the Jain diaspora in the USA. Both domains are significantly intertwined and offer a contextual background to explore the diasporic experiences of the Jain community in the USA. This section takes diverse scopes of 'diaspora' into consideration to support my ethnographic study of the Jain diaspora in the USA. 
Social scientists and historians describe various aspects of diaspora to measure distinct or sometimes inaudible meanings of dispersed individuals, groups or communities across the globe. I will begin by discussing various definitions of diaspora in order to develop my arguments and delineate the phenomena and dimensionality of the Jain community in the USA. Vertovec defines “diaspora” as:

The term often used today to describe practically any population which is considered 'deterritorialised' or 'transnational' - that is, which has originated in a land other than which it currently resides, and whose social, economic and political networks cross the borders of nation-states or, indeed, span the globe (2000: 141).

Describing diaspora, James Clifford (1994) writes, “diaspora discourse...for reasons having to do with decolonization, increased immigration, global communication and transport - a whole range of phenomena that encourage multi-locale attachments, dwelling, and travelling within and across nations” (306). Robin Cohen also presents a range of notions of diaspora that includes concepts such as dispersal from an original homeland, often traumatically; alternatively, the expansion from a homeland in search of work, in pursuit of trade or to further colonial ambitions; a collective memory about the homeland; a strong ethnic group consciousness sustained over a long time; a sense of coresponsibility with co-ethnic members in other countries; and the possibility of a distinctive creative, enriching life in tolerant host countries (2008: 161-62). These perspectives on the meaning of diaspora inform my discussion of the Jain diaspora community in the USA.

Specifically, three depictions of diaspora identified by Vertovec are relevant here to examine and discuss the negotiations among the Jains and invented form of Jainism. They are: diaspora as a social form; as type of consciousness; and as a mode of cultural 
reproduction (2000: 142). These three depictions of diaspora play out very well in the Jain diaspora community in the USA. I argue in this study that the Jain diaspora in the USA demonstrates shifts, innovations and developments at the various levels and spectrums (see Figure 1). As a preliminary remark, I will say that my study on the Jain diaspora community reveals structural implications of the three depictions at the level of individual, the communal and social; and various spectrums of religious matters such as doctrinal, ritual-visual culture and philosophical.

The concept of diaspora as a social form applies to Jains in the USA because of its salient feature, the sectarian negotiations. The sectarian negations are social processes through which the Jain diaspora shapes itself to existing conditions in the USA. I argue that the sectarian negotiations, as a diasporic social process are reflected on two important levels of the Jain diasporic experience. These are the formation of a common, formal Jain community, and the creation of common Jain centers (temples). Religious considerations play a pivotal role in pushing these negotiations. The quest is for a common religious foundation on which the diaspora can be built. I will discuss the nature of the sectarian negotiations as social processes in the diasporic context in the chapters that follow.

The study shows how the 'invention’ at the religious level by the diaspora Jains in the USA is a typical reflection of diaspora as type of consciousness. According to Vertovec (2000), this kind of diaspora consciousness occurs through a particular kind of self-questioning stimulated by conditions of 'diaspora' coupled with religious pluralism. Under such conditions, believers are often compelled to realize that the routine habitual practice, rote learning and ‘blind faith’ underpinning previous contexts (where their faith 
may have been homogeneous or hegemonic) are no longer operational (149). The 'invented tradition', the Jain diasporic phenomena resulting from the 'sectarian negotiations,' reflects a merging of these two concepts: diaspora as a social form and a type of coconsciousness. While, the concept of diaspora as a social form speaks to the 'sectarian negotiations', the concept of diaspora as type of consciousness appropriately engages the 'invented tradition.' My point here is that the dynamism that made possible the creation of a new form of Jainism is the self-realization of the diasporic conditions of the Jains in the USA. In the chapters of the study we will see that the Jain diaspora community acknowledges its status as a religious minority, as a community marginalized by the lager Indian diasporas.

Moreover, the Jain diaspora realized that to survive in the USA, it has to erase the sectarian barriers. To discuss such a shift in a religious self-consciousness, In chapter 6 , I use Clifford Geertz's assertion that there are situations in which the primary question in religious practice shifts from "What shall I believe?” to "How shall I believe it?” He argues that this shift entails further, “a distinction between 'religiousness' and 'religious mindedness,' between being held by religious convictions and holding them” (1968: 61). He notes how the believer may now be in a position to rationalize and justify elements of belief and practice to members of other faiths (ibid.). Applying Geertz's ideas to the development of a 'religious diaspora consciousness' among the Jain diaspora community in the USA, I argue in chapter 6 that the goal was to rationalize and justify the consciousness to create a new form of Jainism. The new form of Jainism, the 'invented tradition,' is a use of faith from various sects and doctrinal beliefs pertaining to Jainism through re-consideration and re-configuration. We will see in the chapter 6 that the Jains 
in the USA manage sectarian specific religious doctrines and philosophies in an accordance that fit their diasporic needs and as a result invent a new version of Jainism. In keeping with Geertz's argument, I show in chapter 6 how the new form of Jainism is a shift from "religiousness” to “religious mindedness” (1968:61).

\section{Conclusion}

In this chapter I discussed the theories I used to develop my arguments in this thesis. I demonstrate links between the theme of the sectarian negotiations and the concept of invented traditions as they manifest at various levels in my study. I also discussed concepts of diaspora that are relevant to the analyses of the structural context of the Jain diaspora community in the USA, I will revisit many of the concepts introduced in this chapter throughout my discussions I present in the chapters of the thesis. 


\section{CHAPTER 2}

\section{The Story of My Fieldwork: The Methodical Considerations}

\section{Introduction}

Because ethnography is not only a product but also a process, in this chapter, I want to say something about the processes I used in studying Jains in the USA. Ethnography finds its roots in the fields of anthropology and sociology and its origin lies in nineteenthcentury Western anthropology. It is considered "a descriptive account of a community or culture, usually one located outside the West” (Hammersley and Atkinson 2007: 1). I find Laura Nader’s (2011: 211) assertion, “ethnography itself as well as its explanatory use is a theoretical endeavor," useful in underscoring the relevance of ethnography for my study. I agree with her assertion that "Ethnography, whatever it is, has never been mere description. It is also theoretical in its mode of description. Indeed, ethnography is a theory of description” (ibid.). Thus, ethnography largely informed my choice of it as the appropriate methodology for my study. I used ethnography to examine the various levels and spectrums of the sectarian negotiations and the 'invention' of a new form of Jainism among the diaspora Jains of the USA.

My research is a multi-sited and multi-level ethnographic study. I conducted the study at four sites/communities (Jain centers-temples) in the USA. These are New York, South Florida, Chicago, and Phoenix. I identified the following three areas of analysis: 1) how the Jain community members find themselves as part of a diaspora community within the USA; 2) the very specific kinds of negotiations they created at sectarian, individual and community levels; and 3) the religious inventions they have created in the 
diasporic settings. Much of the data for this thesis was collected during the summer of 2016.

It is necessary to describe the portions of my fieldwork in this study. Every portion is interconnected and overlaps in the analysis I made of the data on the four Jain communities and the centers-temples in the USA. The portions include the geographical settings of my study, participant observation, interviews, and my positionality as the researcher.

\section{Geographical Settings: The Sites}

My objective in this section is to locate my research geographically by describing briefly the four sites I visited and studied. This section serves as an important part of my thesis as it describes the geographical, demographical and organizational settings of the four Jain centers/temples I studied and analyzed in the research. In this section, I also portray the four Jain communities' basic details in order bring out their contextual settings in my research. This section serves to be indispensable as it allows understanding the profile of all the Jain temples and the communities as I will present my evaluations and arguments on the sectarian negotiations and a new form of Jainism keeping the profiles of Jain temples and communities as reference throughout my thesis.

Jain Center of South Florida is the first Jain temple I studied (pictured below in Figure 2). It is located in Weston, a city in Broward County. The Jain Center of South Florida is a relatively small organization, with 100 to120 Jain families. Prior to 1993, only a small number of families gathered for Jain religious and social activities. The community formed the center in 1993 and established its bylaws in 1995. Initially, the community wanted to construct the temple in a location next to a Hindu temple in this 
area, but because of various zoning laws revisions, the county denied the permission to construct a temple. Finally, in late 2005, the center built a temple in 4,000 sq. feet of commercial office space in a newly built industrial park in the beautiful city of Weston. The temple is easily accessible from interstate highways. One can mistakenly identify the center as one of the commercial sites from outside distance, as its architecture does not feature a superstructure or a sikhara (spire), which is typical of Indian temples. The temple is a single-storey building with two entrances, which directly open to the parking space of the commercial complex. The temple serves the Jain community members from the neighboring areas cities such as Naples, Ft. Myers, Palm Beach, Miami, Kendell and north.

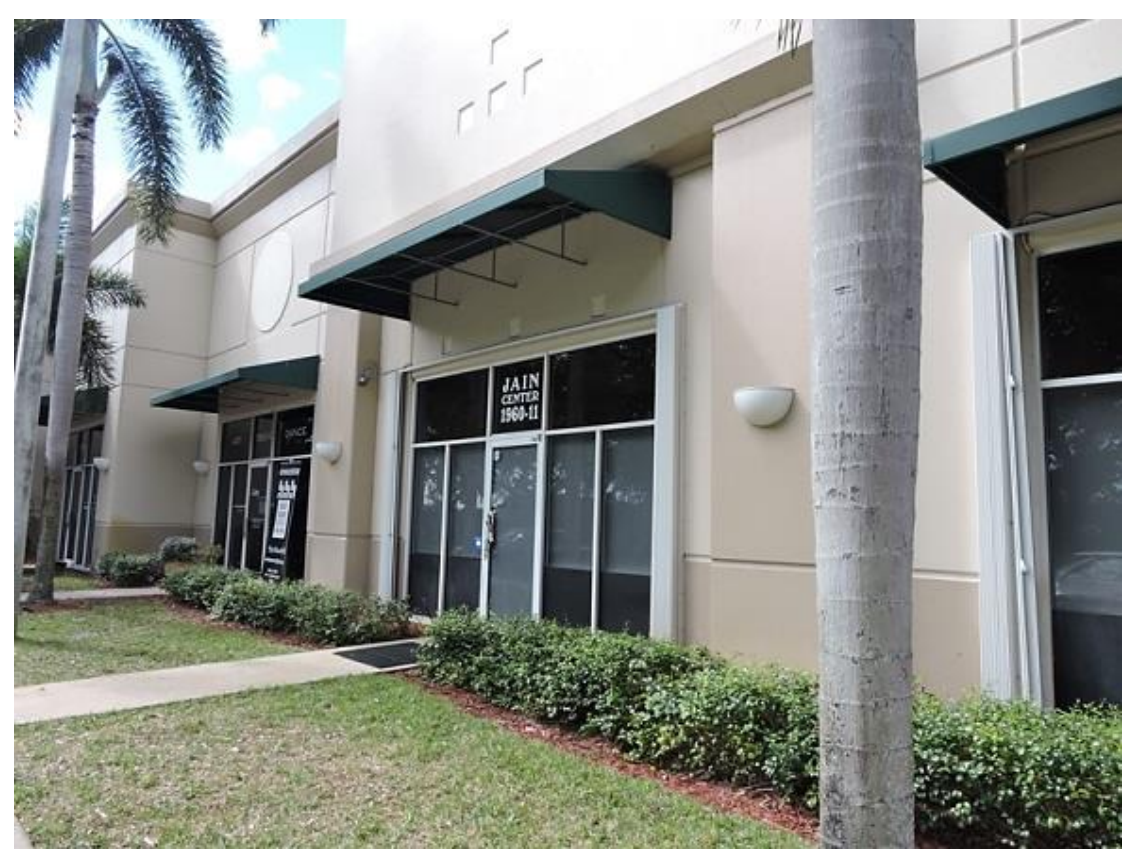

Figure 2. The Jain Center of South Florida

The second site of my fieldwork is the Jain Center of America-New York (pictured below in Figure 3). This center was completed and registered in 1976. In its 
formative years, the members of the Jain Center of America-New York only had an organization. There was no permanent meeting place. In 1981, the community purchased a residential building in Elmhurst, in the borough of Queens, New York, and converted it into the Jain Center. In June 2005, the Jain Center of America-New York constructed a new temple to replace the original temple building. The current temple complex comprises a 16,625 sq. $\mathrm{ft}$. of area with four stories and a cellar. The temple is situated in a busy residential area of Queens with a rich diversity of foreign-born populations. Its location facilitates easy access to it. There are a few Christian churches and Hindu temples in the neighborhood of the temple. One of the Churches stands directly in front of the temple. The temple's sikhara, which is easily visible from a distance, betrays its identity as a Jain worshipping center. The Jain Center of America-New York is an organization of 1,000 to 1,200 families from New York.

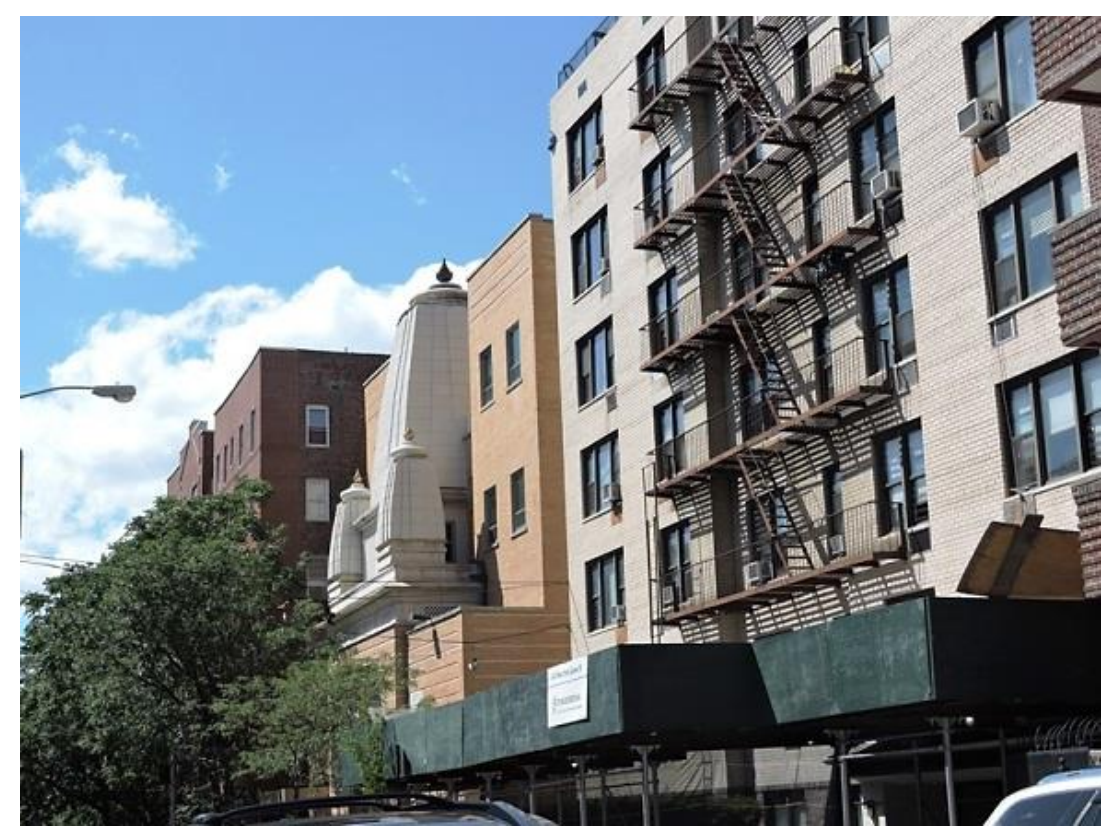

Figure 3. Jain Center of America-New York 
The third site of my fieldwork is the Jain Society of Metropolitan Chicago (pictured below in Figure 4). Founded in 1970, the Jain Society of Metropolitan Chicago has a membership of about 1,800 families. Surrounded by a lush, green campus, the temple was built in 1992 on a 15.4-acre property it owns in Bartlett, Illinois. The idea of organizing a Jain Society in Chicago, incepted in 1969, gradually progressed through various stages and culminated in the construction of a temple. The temple had grand rites of consecration in 2009. The temple has a large cellar space and a semi-structured first floor. Constructed in white marble with a sikhara, the temple is located in peaceful surroundings and is easily accessible to the main highway.

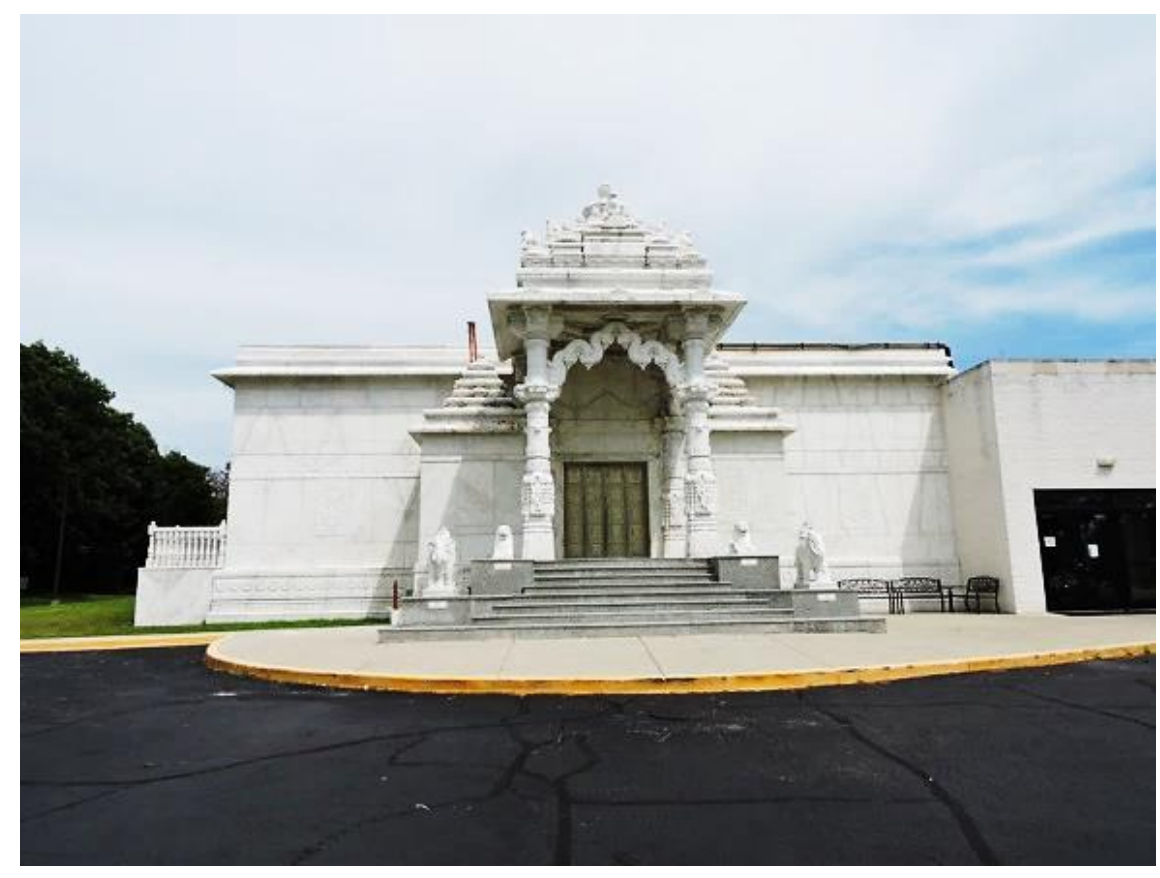

Figure 4. The Jain Society of Metropolitan Chicago

The last and fourth site of my fieldwork is the Jain Center of Greater Phoenix (pictured below in Figure 5). The center has been established for 25 years. It represents about 150 families in the Phoenix metro area. In 2005, the center acquired four acres of 
land for building a Jain temple in Phoenix. A śilānyāsa (foundation stone) ceremony of the temple was conducted in 2007, and the construction started in April 2008. The temple is constructed with yellow-red colored stones, which match with the landscape of the city of Phoenix. The temple has a carved arch entrance and a tall pillar in the white marble next to it. The pillar, a symbol of ahims $\bar{a}$ (non-violence), does not only portray the temple's Jain status, it speaks largely to the community's emphasis on nonviolence as a core value. The temple complex has a separate area used for dining and pāthaśälās (religious teaching programs).

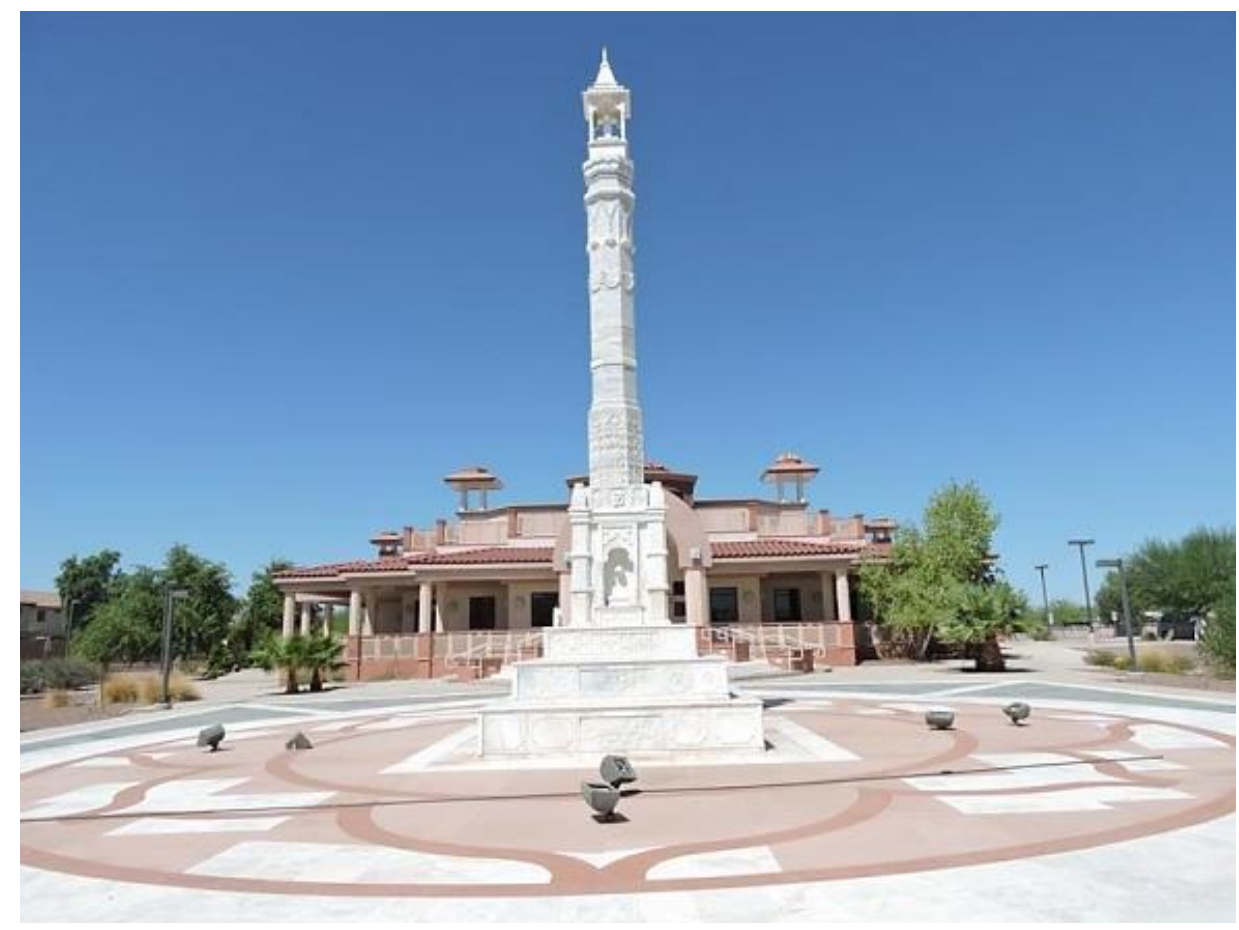

Figure 5. The Jain Center of Greater Phoenix

\section{Participant Observation}

Participant observation, a qualitative method, has its roots in traditional ethnographic research. Participant observation processes entail systematic and active description of events, behavior and artifacts of a setting selected for a study; informal interactions and 
interviews of people, and putting everything together in a detailed field notes (Marshall \& Rossman 1989 and Dewalt \& Dewalt 2002). The objective of this section is to present a brief introduction of my experiences, and the discoveries I made through my immersion and participation in the Jain diaspora communities I studied in the USA. My participant observation for this research involved making trips to the temples during the summer of 2016. The Jain community members usually gather in large numbers at the temple on Sundays. Hence, I visited all the four temples on Sundays in order to gain insights and contextual understandings of the temples' members. I also visited the temple of New York and South Florida during special religious celebrations. For example, I participated in an anniversary celebration at the Jain Center of America - New York and in the celebration of the paryușan ${ }^{2}$ festival and Mahāvìra Janma Kalyānaka (birthday of Mahāvīra) at the Jain Center of South Florida.

I made a point of establishing rapport with the Jain community members during my visits to the temples. I made many efforts to observe and understand perceptions and significance of the sectarian negotiations from the view points of the Jain community members. I also observed and examined the visual and ritual cultures of the temples in order to analyze the elements of invented tradition represented through the visual and ritual cultures. My participation in the rituals conducted and pāthaśălās at the temples helped me to understand the new form of Jainism being 'invented' by the Jains in the USA. In this way, participant observation helped me to uncover the pragmatic and

\footnotetext{
${ }^{2}$ Paryusana (abiding) is the most significant festival for the Jains is which falls during the period of four months from July to October and is celebrated in the month of Śrāvan and Bhādrapāda, late August or early September each year.
} 
cognitive elements, norms and perspectives that underlie the observable behaviors of the diaspora Jain community members.

My status as a Jain enhanced a variety of experiences I had as an ethnographer during my visits to the temples. This constitutes my participation in and observation of new forms of ritual and visual cultures. Gatherings of the Jain community members at the temples provided me with many opportunities to interact with them. Informal conversations during group chats and after worship chats proved to be good learning experiences. My participation in the rituals and conversations provided me with contexts in which I could explore perspectives and experiences of the community members. At every visit to the centers, I could carefully examine their physical environment and human experiences through participant observation. I spend time and great efforts in building rapport and observing or participating in ritual activities and other processes. This benefited me in that I had a sufficient range of experiences, conversations, and interviews to use as basis for my analysis. My participation provided me necessary data to address the issues I had for this present study.

\section{Interviews}

The aim of the interviews in this study was to collect information on members' views on topics such as their experiences as a diasporic religious minority in the USA, the processes of sectarian negotiations, and thoughts on the form of Jainism they were practicing. The interviews I conducted were formal and open-ended. The interview questions were mostly informal and unstructured in order to elicit original responses from the members. I conducted the interviews mostly during my visits to the temples. At all the sites, one or two community members initially accompanied me, but, on successfully 
developing a rapport and building trust, I could freely interact with the members in subsequent visits. I conducted the interviews at any time it was convenient, that is, during communal gathering, before and after worship; during communal meals; and while performing the rituals.

The interviews ranged from five minutes to one hour. I conducted individual, pair and group interviews. I interviewed community members from various sects, linguistic and geographical backgrounds, castes and genders. My interviews include interactions with children, youths, and adults, that is, first-, second- and third-generation Jain diaspora community members. I specifically devoted time to interviewing the gatekeepers, executive members, presidents, and community leaders in order to understand the decision-making that informed negotiations and the 'invented tradition.'

The interviews I conducted mostly opened with mutual introductions between me and the member of the community. I made a number of follow-up interviews by telephone to seek clarification on issues we had discussed in the temple. The kinds of questions I asked the Jain diaspora community members elicited reflections on respondents' personal, sectarian, and community experiences. Interestingly, in the beginning of most interviews, the community members were curious to know my sectarian affiliation, family background and geographical affiliation. This talks about my positionality as a researcher; I will discuss in detail in the next section.

\section{Researcher Positionality}

This section discusses my positionality and reflexivity as a researcher, emphasizing its influence on my study. The dichotomy of the insider-outsider status in fieldwork based research calls for identifying a researcher's positionality in the research context. Griffith 
points out how a researcher is "always located somewhere" (1998: 374). The notion of positionality enhanced my understandings of the complex connections between me and my research; and I linked the ideas of reflexivity and positionality beforehand, throughout and after my research process. I followed Creswell's assertion, "interpretations of the data always incorporate the assumptions that the researcher brings to the topic" (2013: 83); and Sultana’s concept that "It is critical to pay attention to positionality, reflexivity, the production of knowledge and the power relations that are inherent in research processes in order to undertake ethical research...” (2007: 380) in order to maintain the point that it is not possible to detach a researcher from the research.

I use Shulamit Reinharz's (2011) tripartite framework to elaborate on the many facets of my positionality in this research. Reinharz suggests that for each ethnographic setting, a researcher must recognize "what aspects of the researcher are significant, what the meanings of those aspects of the self are, and how those meanings affect the way the researcher can carry out her/his fieldwork” (2011: 5). She proposes that a researcher brings three types of "selves” into a research; they are "research selves”, "personal selves", and "situational selves" (ibid.). With this reference, I locate myself within two positionalities in this research: research 'self' and personal 'self.' It is in the light of these notions of positionality, that I discuss how I affected the field of research and how it in turn affected me.

I have tried to integrate some of my personal experiences before and throughout the study into my analysis of the Jain diaspora community in the USA. I therefore find it appropriate to start this discussion with a brief introduction, identifying myself, and explaining why and how I am studying what I am studying. This brief will also provide a 
context for discussing my positionality. I grew up in a Jain family; in other words, I can identify myself as a Jain who comes from a family that follows Jainism as a major tradition. Living in a secular country - India - among the majority Hindu community, my identity as a 'Jain’ became more formalized after Jainism received the status of minority religion in India in January 2014. To be more specific, I belong to the Sthānakavāsī (nonimage worshipper) sect of Jainism. To add to my biographical affiliation, I come from a Gujarati family, reside in a city on the west coast of India.

I began my student life at Florida International University, Miami in South Florida in fall 2015. Being Jain and an international student from India I was desirous to visit a local Jain temple. My first visit to the Jain temple in Weston gave birth to my interest in the present study. The realization that worshippers blended different sectarian traditions stunned me. When I was in India, my experience of Jainism was oriented by my sectarian attitude as a Sthānakavāsī Jain. My occasional visits to Jain temples and participating in ritual worship; and visiting Śrīmad Rājcandra temples were the only opportunities I had to be exposed to other sects of Jainism. My knowledge of other sects was inadequate; rather, my cross-sectarian encounters were informal. Moreover, I saw other Jain sects as representations of 'others' than my own sect. I grew up seeing each sect following its inherent tradition and according to its sectarian attitudes. Until my visit to the Jain temple in Weston, I could not imagine a formal Jain community practicing a multi-sectarian form of Jainism in a common sacred space. That day I also took note of the different ways in which the multi-sectarian Jain form played out in the temple's worship culture, that is, at the ritual, visual and philosophical-doctrinal levels. In addition to the multi-sectarian religious practice of the temple, I noted the ease with which 
worshippers made social contact with each other in the temple. My research of other temples would reveal how Jain communities in the diasporic setting in the USA represent a coming together of members of different castes, languages, geographical affiliation and cultural backgrounds. This raised my curiosity. My curiosity turned into an academic nous when I took the Religious Studies department's core course in fieldwork.

All students in the class had to conduct fieldwork and prepare a short reportpresentation at the end of the semester. In the third week of the course, we all had to come up with a research problem. When it was my turn, the professor asked, "What is your research problem?” This was the question which prompted me to reflect on sectarian negotiations among Jains in the USA, because immediately my experience in the Jain temple echoed in my mind. That was when I decided that I would research the Jain temple at Weston, South Florida, for my class project. The professor appreciated my findings when I presented my report in the last week of the class. He called me aside and in a lengthy conversation encouraged me to take a closer look at this religious community and its social and religious activities. I was very excited about the professor appreciating my findings. I felt I had stumbled upon some new religious experience. I talked about my fieldwork and basic observations about the sectarian negotiations and religious innovations with my major supervisor, who encouraged me to develop this research problem as my M.A. thesis. I had already started working on the Jaina epistemological theory of anekāntavāda (non-absolutism) as my thesis topic. However, I was so driven to conduct the study that I changed the topic of my thesis. I made up my mind and decided to study this new, unique and creative phenomenon among the Jain diaspora community in the USA using ethnographic methods. I gathered information about other Jain 
temples across the USA and learnt that similar practices are unfolding at most other Jain centers.

I charted out a formal research proposal and began my fieldwork at four different sites. I was a researcher with specific privileges as well as challenges because of my positionality. I present my positionality and issue of reflexivity in the present study to show how they have affected my research at various levels such as entering the field, building rapport, collecting data, participant observations, interviews, and analysis of the findings.

My research 'self' for this study is related to my academic background as a student of religious studies. I entered the field carrying my identity as a researcher who is conducting a study of the Jain diaspora community in the USA. This helped me understand the research problem and formulate research questions in the setting of the study. My positionality as a student and researcher shaped my critical standpoint and I opted to be a 'criticalist' (Carspecken 1996: 3). While giving emphasis to the Jain community members’ responses, I was attentive to contextually situated realities and meanings (Luckmann 1967). I was careful not to formulate any interpretation with a single viewpoint or absolute perspective. Rather, I gathered data by acknowledging the representation of multiple points of views from the range of perspectives of the community members. The various interpretations offered by the members elucidated the phenomena I studied.

My positionality in accordance with personal 'self' represents an element of epistemological importance in the shaping of my research. As Madison points out, “positionality is vital because it forces us to acknowledge our own power, privilege, and 
biases” (2012: 8). For this reason, element of reflexivity are persistent in my thesis and serve to focus how my positionality impacts upon my relationship with the Jain community members and temples I encountered. Researcher positionality can influence all stages and aspects of the research; as Foote and Bartell points out, "The positionality that researchers bring to their work, and the personal experiences through which positionality is shaped, may influence what researchers may bring to research encounters, their choice of processes, and their interpretation of outcomes” (2011: 46). My personal 'self' as an Indian, Gujarati, Sthānakavāsī Jain effectively organized my positionality in examining the sectarian negotiations and a new form of Jainism among the diaspora Jains in the USA. I carried my Jain identity and background to the field. In other words, my personal experience, being a Jain from India shaped my position in the field and affected the interpretations in my study. To be more specific, aspects of my personal 'self' affected my research process at three stages. First, my positionality as a Jain played a vital role in gaining easy access and entry in the field. I could promptly achieve a level of trust among the gatekeepers of the Jain centers and community. I easily build a rapport with the Jain community members. In addition, I experienced fewer challenges in collecting data. My positionality as a Jain perpetrated a welcoming and opened access to gather data in audio, video and visual formats. Moreover, as I was aware of essential Jain ritual and visual elements in the temples, I was quickly able to see/identify the unique features of 'invented' forms of visual and ritual cultures at the temples and during special religious celebrations.

Second, my positionality as a Jain constantly improved participant observations and interactions in the study I carried out. My positionality played a vital role in 
interpreting the multi-sectarian attitudes at religious and social levels. By way of adding my personal self as a Jain in this research, I went to the field with basic familiarity with Jainism. However, Jainism in diasporic setting was a different experience for me. I came to the USA with my sectarian understanding of Jainism. I had never performed any rituals in a Jain temple in India. Even with my identity as a Jain, I persistently strived to be a comfortable fit in the rituals performed at the temples during my fieldwork. Since diaspora Jains have created a new form of Jainism, the rituals also demonstrate sectarian blending and hybridity. Indeed my personal 'self' as Jain was reshaped throughout my fieldwork as I encountered a new form of Jainism. My positionality as a Jain also affected my observations of the visual culture at the temples. I could easily understand the arrangement of multi-sectarian images in the temples. Sharing similar religious, linguistic and sociocultural background with the participants was a good advantage for me while observing rituals and conducting interviews. The interviews were comfortable for me and for the Jain community members I studied. "What is your understanding of and orientation towards Jainism?” and "What differences do you see between here and in India about Jainism?” - These were the two most common questions my respondents asked me before I even began to ask them any questions. This relates much to the personal 'self' I carried with me to the field. At most times, my positionality was perceived as a fellow Jain, and then as a researcher. However, I was rarely asked about my sectarian identity or caste during my interactions with the community members. This demonstrates that the diaspora Jains are less attentive towards the sectarian and other identities in their present context. 
My Gujarati background was the other major factor of my positionality in this research. Being a Gujarati from India, I had experienced cultural, geographical and lingual differences between Gujaratis and people from the other parts of India. However, my interaction with the diaspora Jains who belong to various cultural, geographical and lingual backgrounds inflected my personal 'self' and determined my position in relation to them. My positionality as Gujarati was replaced by my identity as Indian because the diaspora Jains' formation of the sectarian negotiations underplays the identity markers like caste, language, geographical background, etc.

Third, I was paradigmatically aware of my personal 'self' as Jain throughout the designing and execution of my research. In qualitative research, the inquirer reflects about how their role in the study and their personal background, culture, and experiences hold potential for shaping their interpretations, such as the themes they advance and the meaning they ascribe to the data. This aspect of the methods is more than merely advancing biases and values in the study, but how the background of the researchers actually may shape the direction of the study (Creswell 2014: 235). Specific to this point, my positionality as Jain was enhanced as I adopted reflexivity approach to explicit the interpretations of findings of my research. Reflexivity and positionality became key terms in the perspective of ethnographic research (Hammersley and Atkinson 2007). Considerably, I began to reflect critically on my positionality as soon as I began to infer the theme and the concept from my research. I reflexively examined the impact of elements of my personal identity. I included reflexivity to understand the dynamics of my positionality as a Jain, a female, and a Gujarati who is studying the diaspora Jains in the USA. In other words, my identity markers as a female, Gujarati researcher who is also a 
Sthānakavāsī Jain from India certainly influenced many aspects of my research such as my access to the sites, as well as my participant observations and interactions with the Jains participating in my research. My positionality also affected my perception of the Jains in the USA, their processes of the sectarian negotiations and invention of a new form of Jainism. I determine cognizance through reflexivity to interpret these elements. Therefore, as I talk about reflexivity, I do not simply mean that I include my positionality experience in the discussion. Nevertheless, importantly, I acknowledge the role my identity markers play in the shaping the research process. I also acknowledge impact of my positionality on my interpretations and production of knowledge about the diaspora Jains in the USA, their sectarian negotiations and 'invented' tradition. Therefore, I demonstrate a critical self-examination of my positionality throughout my thesis.

\section{My Experience of the Fieldwork}

My fieldwork experiences added a new dimension to the way I understand Jainism. For example, I began to take interest in other sects than my own as I became familiar with multi-sectarian and 'invented' Jainism at the temples I studied. I consider that my field visits gave me opportunities to know Jainism with diverse perspectives. For example, a

new form of Jainism designed by the diaspora Jains in the USA which features mixture of diverse sects occasioned me to learn about Jainism with multiple viewpoints. Further, for the diaspora Jains in the USA Jainism is an all-inclusive Jain tradition that embraces and combines features of all the sects. This allowed me to be familiar with different sects under one roof. On a personal note, I acknowledge that I developed special interest in the Digambara tradition during my field visits. Unlike in India, the negotiations among the Jains in the USA allow an individual to participate in multi-sectarian Jainism. Moreover, 
I learnt from that the negotiations among the Jain diaspora community in the USA that differences can also be used to invent, to create a new tradition at social and religious sphere.

\section{Conclusion}

The discussions of the methodical considerations in this chapter are essential to the analyses, evaluations and interpretations I made in my ethnographic study of the Jain communities in the four different cities in the USA. 


\section{CHAPTER 3}

\section{Jainism, Sectarian Developments, a Contour of Jain Identity and the Diaspora Jains in the USA}

\section{Introduction}

What background and framework entail the American diaspora Jains' social and religious settings? What are the social, religious and historical backgrounds of the Jain Diaspora community of the USA? This study analyzes the forms and effects of the Jains' sectarian negotiations and the new form of Jainism emerging in the USA. As members of the diaspora Jain community in the USA have their social and religious roots in India, it is necessary to understand the religious and social ingredients they carried with them from their motherland to the land of settlement. This is the focus of the discussion presented in this chapter. Although my research is not a comparative study of Jains in the USA and India, the thesis requires a portion that discusses Jainism in India, emphasizing the attributes of 'Jain’ identity in an Indian context. This backdrop is important for us to understand the emerging patterns of Jainism in the USA diaspora. Since, the negotiations and the new form of Jainism are the products of transmutations Jainism is going through as it moves from an Indian version to an American version, it is also essential for me to discuss the sectarian phenomenon typical of the Jain tradition in India and how this has impacted Jain identity before the migration to the USA. With these referent points in mind, this chapter will provide a brief introduction to Jainism, and discuss the sectarian splits within Jain tradition, the sectarian attitudes, and the identities the diaspora Jains carry with them from India. The chapter also presents a brief review of relevant literature on diaspora Jains in the USA. This chapter will help to support my interpretations of the 
Jains and Jainism in the USA that feature the negotiations at social and religious levels; and in the form of the invented Jainism discussed in the chapters that follow. I weave the discussion around three claims. First, I argue that the accounts on the development of a Jain identity in the history of India demonstrate that the Jains have been involved in an age long struggle to achieve an independent religious identity among the majority Hindus and other religions in their own homeland - India. I discuss the different phases of the active and conscious struggle of the Jains to be identified as independent religious and communal identity, mostly 'other' than Hindu showing how the ongoing project by the Jain migrants in the USA to be recognized as distinctive religion and community is simply an extension of the struggles in the past. The second argument I present here is based on the sectarian profiles of the Jains. The Jains in India represent a very rich diversity of sectarian attitudes. However, they have remained to be very small in number; the Jains in India maintain sectarian features and demonstrate few attempts to interact with other sects within Jainism. With regards to the matter of sectarian identities, the Jains in India also identify with other identity markers such as caste, language, cultural background, and geographical affiliations. The third argument I make is that all of these identity markers are taken in full considerations and reflected upon by the Jains as they interact to create a larger Jain community in the USA.

\section{Jainism}

As a lived Indian religious tradition, Jainism belongs to the śramana tradition and is known for its cardinal principles of ahimsa (non-violence), aparigraha (non-possession) and anekāntavāda (non-absolutism). According to the two-fold division of Indian philosophy, Jainism falls under the heterodox system along with the Cārvāka and the 
Buddhist systems (Jaini 1991). Jainism's beginning is traced to the period between the 7th-5th century BCE. From this period it developed into a religious system that has significantly contributed to Indian philosophy and logic. Emerging towards the end of a time of great social transformation in north India, the hallmark of which was the emergence of ideas that were in sharp contrast to the dominant sacrificial practices of Vedic Brahmanism, Jainism adopted a method of salvation based on the practice of nonviolence and asceticism (Flügel 2006 and Cort 2001). Jainism is a term derived from the word jina which literally means 'a conqueror', the one who has by his or her own determined efforts conquered the worldly passions like desire, anger, hatred, pride, greed, etc., and has been liberated oneself from the bonds of samssāra, the cycle of births and deaths. The designation for the term 'Jain' in ancient scripture was niggantha (free from bonds), and this was used to describe only members of the ascetic community (Dundas 2002 and Gopalan 1973). Jainism was founded by human spiritual teachers known as the Tîrthankaras (also known as Jinas) or ‘ford-makers’. The first Jina in this era was Ṛșbhanātha, also known as Ādinātha (first Lord). Other Important Jinas of the Jain universal history were Śānthinātha, the sixteenth Jina; and the last three, successively Neminātha, Pārśvanātha and Vardhmāna Mahāvīra. According to the Jains, Neminātha lived in western India and was a cousin of Kṛṣna; Pārśvanātha lived in the eight Century BCE in Banaras; and Mahāvīra lived a little over 2,500 years ago in today the state of Bihar in northern India (Cort 2001). In all, there were twenty-four Tīrthankaras; and Mahāvīra is considered as the last of the Tīrthankaras who preached and extended philosophy and ethical teaching of Jainism. Jainism regards mokșa as the major and final aim of human life and coordinates with the doctrine of karma; and ethical codes and 
practices. Cort's (2001) mention of Jainism as a lived religious tradition asserts it as a tradition that presents normative ideology of mokșa-marge, the path to liberation. In Jaina understanding, karma is seen as an instrument for an individual to attain liberation. The soul (self) needs to be released from the negative influence of karma so that the person can commence right conduct. Jainism, in this regard asserts that comprehending what is right conduct is very essential to determining and regulating the karmic inflow; and right conducts is acquired only by developing an enlightened world-view and an enlightened knowledge. These three notions are known as the three jewels and relating to them are the five abstinences or vows: non-violence, truthfulness, not stealing, non-possession and chaste living. In Jainism, these five vows are the prescribed ethical principles or codes of practice to be followed by householders and ascetics. Ascetics follow the observance of the vows strictly. The vows are moderately relaxed for householders. Jains reject the idea of God as the creator, but do not reject the concept of God. All twenty-four Jinas are collectively the God of Jains, and the larger Jain pantheon includes various unliberated souls.

Jaina metaphysics, the notion of ontology and theories of epistemology are at the core of development of broad Jaina philosophy, and specifically non-violence and anekāntavāda (doctrine of non-absolutism). Knowledge, logic and epistemology are innate part of Jaina literature and noticeable at a large spectrum. Mahāvīra in the Jain Āgam (Jaina canonical text) Bhagavatī Sūtra referred to four means of valid knowledge such as perception (pratyakșa), inference (anumūna), analogy (upamāna), and authority 
(āgama). Umāsvāti in Tattvārtha Sūtra ${ }^{3}$ describes five varieties of knowledge as empirical (mati), articulate (śruta), clairvoyant (avadhi), mind-reading (manahparyāya), and omniscient (kevala). These five varieties of knowledge are further divided into two classes: acquired and innate. Discussions on knowledge in Jaina literature gradually advanced and focused on pure logic and epistemology. It can also be proposed that anekāntavāda played a vital role in comprehending the concepts like liberation and karma. Reality, according to Jain metaphysics consists of six eternal substances and each substances is associated with certain qualities. The six substances are space; principle of motion and rest; physical order and existence; and time. Anekāntavāda's development can also be discussed with reference to Jainism's rich traditions of non-violence and tolerance.

The Jaina principle of 'respect for the life of others' gave rise to the principle of respect for the views of others. Mahāvīra carried the concept of non-violence and tolerance from the domain of practical behavior to the domain of intellectual and philosophical discussion. Jaina canonical literature provides discourses on the nature of ahims $\bar{a}$. For example, Jain Āgam Acharang Bhasyam elaborates on the practices that stabilize the vow of non-violence such as controlling speech, controlling the mind, moving carefully, and etc. Acharang Bhasyam stresses upon enlightened world-view and asserts that confusions and doubts can undermine the observance of the vow of nonviolence and all worldly violent activities which are to be comprehended and given up. It was explained in Acharang Bhasyam that a person with unbiased perception under the consideration of transcendental and empirical standpoints can distinguishes between right

\footnotetext{
${ }^{3}$ Tattvartha Sutra, an ancient non-canonical Jaina text written by Umāsvāti, sometime between the $2^{\text {nd }}$ to $5^{\text {th }}$ century A.D. and accepted by both major sects of Jainism.
} 
and wrong and can adopt the attitude of equanimity. Jaina philosophy rests on the concept of universal interdependence and interconnectivity. It is pointed out in the Jaina aphorism, parasparopagraho jivanam ${ }^{4}$ which translates as 'souls render service to one another.' The concept of parasparopagraho jivanam in Jaina worldview stands important as an ethical framework which asserts relationship and interdependence among all living things. Jainism, in this regard identifies in a natural symbiosis or mutual dependence which supports the modern day concept of ecological ethics. The Jaina aphorism parasparopagraho jivanam is a contextual attitude and it asserts that all life forms are bound together by mutual support. With this reference, the Jaina philosophy also offers scope of ecological ethics and a base for cognitive framework that allows perceiving the understanding that all living elements are bound together in a physical as well as a metaphysical relationship. Life, according to this Jaina concept of interconnectedness, is viewed as an idea of togetherness and accommodation.

\section{Śvetāmbara and Digambara: the Two Principle Sects in Jainism}

I find it important to discuss the sectarian attitudes and differences typical of Jainism in India as I argue that the Jains in the USA have invented a new tradition and established formal Jain communities which incorporate all the sects in a newer context. Thus, the discussion will allow us to understand the nature of the sectarian interactions, negotiations and unity among the Jains in the USA. Also, in this section I will discuss various Jain traditions' sect- specific features. This will enable us to identify the attributes of the new version of Jainism in the chapters that follows. This section and the following sub-sections are the precursors for my analyses and the findings

\footnotetext{
${ }^{4}$ See Umasvati’s Tattvartha Sutra, verse 5.21, p. 131.
} 
Mahāvīra classified his own institutions on the basis of renunciation and rejected the varna system (caste system) and after the enlightenment, he formed the caturvidhasangha (fourfold community) or sakal (complete) saingh. This refers to the congregation of sadhus, sādhīvs, śrāvaks and śrāuikās, respectively states monks, nuns, male laity, and female laity (Sukhalalji 1988 and Flügel 2006). The largest group with which Jains can be linked is the 'sect'. This concept of sect can be further described using various terms such as sangha (community), gaccha (group), gaṇa (mendicant group), samudāy (those with the same origin), parivār (family), and sainghaḍa (smaller groupings) and panth (path). In order to emphasize the worth of a comprehensive study of Jains, Flügel (2006: 312) suggests that we should avoid the inevitable abstractions of general accounts of the Jains, and concentrate on the smaller units of the tradition. In other words, the study of an individual school, sects or order of Jain tradition must precede a study of Jain culture in general. Therefore, first I introduce the two prominent divisions within Jain society which have been that between the Śvetāmbaras and the Digambaras. The final breach between major sects of the Jaina religious community - the Śvetāmbara and the Digambara according to Jaini took place around 300 BC (1991: 1). Cort (2001) describes the division as:

The difference between these two sects is in large part that of mendicant praxis, as indicated by their names, which refer to the dispute concerting whether the true sadhu should shun all clothing and be clad only the directions (dig-ambara), or else should wear simple white robes (śveta- ambara). This major sectarian difference also partially overlaps a geographical one: Śvetāmbars have lived in Gujarat, Rajasthan, and the Panjab, whereas the Digambars have lived in urban north and central India, southern Maharashtra, and Karnataka (41).

Interestingly, there are various versions available in the Jaina literature about the origin and development of the major schism. Giving the Śvetāmbaras' account, eight 
concealments of the doctrine occurred in sixth century after Mahāvīra's attainment of enlightenment and the first of these took place during Mahāvīra's lifetime, apparently originating with his nephew Jamāli. Further, the Śvetāmbaras version of description locates the rise of the Digambara sect 609 years after the death of Mahāvīra. According to Śvetāmbaras, Sivabhuti, a Śvetāmbara monk and his followers were the founders of the Digambara sect. However, the Digambara versions do not mention any particular individual as a founder of the Śvetāmbara sect. As per the Digambara version, the Śvetāmbaras were the Jain community which remained in the north of India during a famine while some co-religious members migrated to the south under the leadership of Bhadrabāhu. However, the splits did not occur abruptly, but through gradual movements among the Jain monks. The final major strengthening of division between these two sects most likely occurred during the Council of Valabhī in either 435 or 466 CE which was formed to codify the scriptural traditions. But, this process remained much exclusive to the Śvetāmbara sect. The Digambara source mentioned no evidence of any naked monk $^{5}$ s s presence at the Council. The Council witnessed the division of the Jain monastic community into two major divisions at the level of geographical distribution. According to the division, naked ascetics, the Digambars predominated in southern India and whiterobed, the Śvetāmbars in western India (Folkert 1993 and Flügel 2006).

There is evidence of social interactions between these two principle sects at various events in the Jaina history--for matters such as authority over holy places, intellectual debates and large-scale pilgrimages. The following details allow us to understand the major developments and the way interactions between the sects have

\footnotetext{
${ }^{5}$ In the Digambara traditions, the male ascetics renounce clothing as a part of the concept of nonpossession.
} 
impacted the flow of their respective expansions in modern to contemporary times. To identify a couple of examples, I mention Dundas's (2002: 51-54) reference that the Śvetāmbara Vādideva's victory in a debate with the Digambaras in 1125 in Pațan confirmed the establishment of the Śvetāmbara doctrine and practice as the official Jainism of Gujarat State. Second, in eighth century CE the Śvetāmbaras attempted to dislodge the Digambaras from Mount Girnār which let the Śvetāmbaras to establish this holy place as a the Śvetāmbara spot, in which the images of the Jinas were clothed, also, adorned with jewelry and auspicious marks. This led the images to become unsuitable to the Digambaras to worship. Dundas mentions an undated Hindi publication which emanated from the Digambara community at Śirpur. He refers to the details in the book and describes the disputes related to the shrine in the following words:

When the Śvetāmbaras first came to Maharashtra, they had no holy place of their own, so they had to adopt Floating Pārśva. The Digambara community had the graciousness to allow their Śvetāmbara brothers to perform worship there. However, this graciousness has had a bitter result in the form of a breach of faith (2002: 54).

The dispute between the Śvetāmbaras and the Digambaras over the Jain pilgrimage site of Bahūbalī hill in Kolhapur District in southern Maharashtra is a relatively greater discussed example of a conflict in regard to the ownership of pilgrimage places. Carrithers (1988) describes dispute:

In early 1983 Digambar and Svetambar Jains forced into public prominence their struggle over the local Jain pilgrimage site of Bahubali hill in Kolhapur District in southern Maharashtra, in India. By the end of that year the majority Maratha community, Harijans, the local and State Congress Party, the police, the district administration, and the State and Union governments were also entangled in the conflict (815). 
Carrithers refers to the incident described above and asserts that the two major sects and subsects demonstrate communal rivalry for reasons such as control over building and renovating temples and retaining strong exclusiveness of each respective sects. Moreover, the communal rivalry between the Jain sects, as he points out "in one form or another, is endemic throughout India" (1988: 818)). He adds that "the minimal conditions for such conflict seem to be that each community came to conceive the other as a significant rival, as a 'significant other', and willing to engage in competitive building programmes" (1988: 818). Carrithers adds to the information that Jains are engaged in sectarian dispute over an estimated 134 pilgrimage sites throughout India (1988: 817). This discussion points out that the two major sects in India have been experiencing conflicts and debates to maintain the authority, uniqueness and control over the religious matters.

Since the split, the two sects refuse to accept the validity of each other's scriptural, ritual and visual culture matters. Each sect is unique and demonstrates differences when compared with the other sects. Therefore, I find worthy to deliberately discuss the major differences among the two sects and subsects in order to analyze the efforts and actions the Jains in the USA have taken towards managing a unity in the USA across the sectarian diversities. We shall note some points of distinction between the two major sects. The following discussion will help us to gestate the quality of the negotiations and the new form of Jain tradition among the Jains of the USA.

Clothing for ordained persons/ascetics. One of the major issues dividing the two sects was the suitability of ascetics wearing cloths. The Digambaras follow Mahāvīra's practice of nudity and claim that an ascetic must renounce all property and possession 
including clothing in hope to attain liberation. Thus, nudity became the primary identifying feature of mendicants in the Digambara sect. In this case, the Digambaras do not grant women permission to renounce clothing and claim that a woman cannot attain liberation since she cannot completely go naked. While, the Śvetāmbaras accept that Mahāvīra adopted the practice of nudity, however, they regard the rejection of clothing as optional for mendicants. Jaini (1991) mentions that "The Śvetāmbars position became increasingly intransigent, however, until the leaders of that sect came to claim that clothes were an integral part of the holy life... and even the Śvetāmbars resorted to eschatological arguments to justify their claim” (2). Thus, the Digambara ascetics live completely naked. The Śvetāmbara monks (male and female) wear simple white cloths. Mokșa for women. Indeed the status of women and its implication for their access to liberation is a major issue of difference between the two major sects. The Digambaras derive spiritual incapability of women from a combination of scriptural authority, scientifically, and logical reasoning to achieve liberation. The Digambaras' position on this view rests also on considering the biological and anatomical ${ }^{6}$ differences between a male and a female. The Digambaras refuse to accept any possibility of a person, male or female, attaining liberation without renouncing one's cloths. For the Digambaras, retention of clothes implied residual sex desire and prohibition for women to renounce clothing lead to the formulation of a doctrine that women are incapable of attain mokșa. The Śvetāmbaras oppose this idea, and regard women's status as capable as men to achieve spiritual liberation. For the Śvetāmbaras, the possession denotes not the material things but mental attachment, and cloths do not constitute as possession and therefore do

\footnotetext{
${ }^{6}$ Because of certain portion of a woman's body give rise to vast number of minute and subtle organisms. See Robert P Goldman's foreword of Padmanabh S Jaini’s book Gender and Salvation (1991: xix).
} 
not prevent a woman from attaining mokṣa. The Śvetāmbaras assert that there is liberation for women, ascribe to the path of liberation through following the three jewels (right-view, right-knowledge and right-conduct) which are described as primary conditions for attaining mokșa in Tattvartha Sutra ${ }^{7}$. Jaini (1991) mentions that the Digambaras rebuttal to this position of the Śvetāmbars stressing upon the part of right conduct which is again according to the Digambaras is impossible for women. The sectarian disputes over this issue also significantly outline the attitudes towards the position of woman as mendicant and her ability to attain liberation.

Iconography of the Tīrthankaras and other visual cultures. The two sects differ in the depiction of the images/icons of the Tirrthankaras. According to the scholarly review of evidences, Jains commissioned and worshiped images as early as the first century BCE (Shah 1998). According to Cort (2010), the evidence indicates that the Jains may have been pioneering in the development of a culture of image worship. Many features of the iconography of the Jinas vary in both traditions. To mention a few here, for example, in the Digambara tradition, the figures of the Tīrthankaras are always male and naked. For the Śvetāmbaras, the images of the Tīrthankaras are clothed and decorated with ornaments. Other major difference is difference in the direction of the eye's gaze of the images. The Digambara images have downcast eyes, while the Śvetāmbara images have staring eyes. Cort points out that "Digambara emphasis on the image depicting the liberated Jina, in contrast to the Śvetāmbara depiction of the enlightened but not yet liberated Jina. This is clearly in the Digambara iconographic tradition of the siddha pratima or image of the perfected one” (2010: 24). The differences are essential to the

\footnotetext{
${ }^{7}$ Tattvartha Sutra is a treatise, accepted as authoritative by both the sects.
} 
level of difference in the ritual cultures of both sects. According to the Jains, a kevlin (enlightened soul - the Tīrthankaras) has thirty-four distinguishing eminences; and there is a difference in the list of these eminences in the Digambara and the Śvetāmbara texts. This discussion supports my analyses in the chapter 5 as I argue for the Jains' invention of a new form of visual culture in the temples I studied where I argue for the Jains' invention of a new form of visual culture in the temples I studied.

Ritual culture and worshipping. The seated image came to dominate Jain iconography, and at least one such image is the focal point of each Jain temple. This image is offered $p \bar{u} j \bar{a}^{8}$ (worship, i.e. homage shown by act of symbolic hospitality) by the Jain lay persons (Folkert 1993). For the image worshiper Jains, darśana (seeing or sight of holy) and two kinds of püjā - dravya püja (external or material worship) and bhāva püja (internal or mental worship) are integral part of the ritual culture. The image worshipers perform rituals with external worship to the image of the Jinas and other demi-gods at the temples or at home. Both the Digambara and the Śvetāmbara traditions have image worshiping sects but there are distinct ways in which both sects perform the rituals. The two major sects have different types of rituals on an everyday basis and for the special religious occasions. Both sects agree on aștprakārī püjāa (the eightfold worship), however, a ritual namely snātra pūjā (the bathing rite) remains exclusive to the Śvetāmbaras. Even though both sects are on agreement about the eightfold worship ritual, there are some specific differences in the methods of performing the ritual. The Digambaras mostly wear saffron colored cloths, while the Śvetāmbaras wear ivory-white colored cloths. The Śvetāmbaras

\footnotetext{
${ }^{8}$ Worship, usually the main act of ritual worship such as anointing the images of the Jinas and other sacred images.
} 
cover their mouth in order to avoid any impurity being breathed onto the image of the Jinas. The Digambara Bīsāpanthīs in north India perform a modified version of the eightfold worship. They do not generally offer the five nectars and minimum amount of water is poured. Dundas (2002) points out that the Digambaras in south India generally do not touch the image of the Jina in the temple and the rituals are carried out by the priest. However, the Śvetāmbaras carry out the rituals themselves (204). Moreover, the Jains form non-image worshiper sects and perform bhāva püjā in the form of sāmāyika or pratikramana (ritualized confession), recitation of verses or meditating upon the qualities of the Jinas. I will explore the diaspora Jains' inventions at the level of ritual culture in chapter 5. I will argue that the Jains in the USA have invented a new form of ritual culture that includes a blend and re-configurations of the rituals from various sects; whereas in India, the rituals exist in their individual sectarian forms without any crossover between the two major traditions or sub-sects.

In regard to Mahāvīra and Māllīnātha. Both sects differ with respect to their views on Mahāvīra's biographical details. Firstly, the scriptures are reliable sources for the understanding of Mahāvīra's earliest stages of biography for the Śvetāmbaras. But, for the Digambaras, the scriptures give no significant early evidences. Sectarian disagreements are also present in Mahāvīra's date of birth and birthplace. Secondly, there are different opinions between these two sects over the reference of Mahāvīra's embryo transfer. The Śvetāmbaras believe that Mahāvīra's embryo was transferred from Devānandā, a Brahmin woman's womb to Triśalā, a Ksatriya woman’s womb. However, the Digambaras disagrees on this issue. Moreover, the Digambaras also reject the episode of Mahāvīra's marriage to Yaśodā. In contrast, the Śvetāmbaras retain this 
episode as truth. For Māllīnātha, the nineteenth Tīrthankara, the Śvetāmbaras maintain and depict Māllīnātha as a woman. However, the Digambaras reject the possibility of a female as $a$ Tīrthankara and worships Māllīnātha as the male Tīrthankara. I argue in chapter 5 that the Jains in the USA have managed to secure a non-conflicting approach towards such variations in interpreting the biographical details of the sacred figures.

In regard to scriptures and doctrines. Jain scriptures contain discussions and knowledge of Jaina cosmology, doctrine, rituals, and many other religious exercises. The scriptures for Jains lay down grounds for understanding philosophical, epistemological, practical, ethical and historic portions of Jainism. One of the main areas of dispute between the two principle sects instrumental in the split has to do with Jain scriptures and different interpretations of them. In Jainism, the canonical materials are termed as Siddhānta (tradition) and Āgamas (doctrine). Jains have clearly delimited a body of scripture containing some forty-five texts in diverse fixed categories. The Digambaras claim that the Jain scriptural tradition has been lost and so Ágamas cannot be designated as anything more than metaphorical accounts. There are differences even in the way a scripture is viewed as a sacred object in both traditions. For Digambaras, Sațkhandāgama is the most prominent of all sacred texts. While, Kalpsütra holds a central place in the Śvetāmbara tradition. The Digambara Jains do not recognize and regard the Śvetāmbara texts as authentic. According to Folkert (1993) “The major divisions in the tradition involve fundamental and sharp disagreements over scriptures. In brief, the Śvetāmbars have established and preserved a canon of scriptures that the Digambara do not accept” (44). Further, some Śvetāmbara sects have placed restrictions on the reading of scriptures by the lay community, while, the Digambaras do allow reading of the scriptures by the 
laity. The Śvetāmbaras and The Digambaras hold different opinions on the disappearance of a large body of scriptural material known as $p \bar{u} r v a^{9}$ (previous/ancient). In addition to this, the Sthānakvāsīs and the Terāpanthīs, the sub-sects of the Śvetāmbara tradition do not accept the enumeration of the Śvetāmbara Murtīpūjakas (image worshippers) scripts. The Sthānakvāsīs and the Terāpanthīs have their own thirty-two-text list. I explore the forms of negotiations among the sects and sub-sects among the Jains in the USA with regards to such doctrinal and scriptural differences and disagreements in chapter 5 . I also argue that in their diasporic context the Jains have reflected on such disagreements and have adopted the strategy of maintaining peaceful accordance, inventing a new Jainism in the process.

In regard to religious holidays/festivals. There is no complete unity between the two major sects with regards to the sacred festival's dating and duration except the date of Mahāvīra Jayantī (Mahāvīra's birthday). The most significant festival for the Jains is Paryușana (abiding) which takes place during the period of Cāturmāsa (holy period of four months from July to October) and is celebrated in the month of Śrāvan and Bhādrapāda, late August or early September each year. Paryuṣaṇa is held for eight days by the Śvetāmbaras and ten days for the Digambaras. The festival is called Daśalakṣanaparvan (festival of ten righteous virtues) in the Digambara tradition. The difference in the duration of the days leads to the Digambra celebrating the Samvatsarī, on the last day of Paryuṣana. The Śvetāmbara Jains celebrate it on the eight day, while, the Digambara Jains celebrate on the tenth day. There are variations in methods and rituals that mark the Paryusana. Central to these festivals is the reading of the sacred Jain text, Tattvartha

\footnotetext{
${ }^{9}$ Each Jina is supposed to have first preached 14 P $\bar{u} r v a s$ before they communicate the rest of the sacred text.
} 
Sutra for The Digambara Jains while the Śvetāmbara ascetics recite the Kalpasutrā. Moreover, dating for the celebration of Saṃvatsarī varies in subsects. For example, the Tapā gacch observes Saṃvatsarī on Bhādavā Bright 4; and other Murtīpūjak gacchs and the Sthānakvāsī and Terāpanthīs observe Saṃvatsarī on Bhādavā Bright 5 (Cort 2001:147). In chapter 5, I will evaluate the invented form of ritual culture and argue that the Jains, in a bid to sustain the notion of community have introduced creative innovations into the religious festivals, amalgamating them into one shared practice.

\section{Sub-Sectarian Developments in Jainism}

The two principle sects, the Śvetāmbara and Digambara are further divided into various subsects. The Śvetāmbara sect's further schism resulted in the Murtīpūjak, the Sthānakvāsī and the Śvetāmbara - Terāpanthīs. The Digambara sect was divided broadly into two major traditions (subsects) such as the Bīsāpanthīs and the Terāpanthīs; and very small traditions (sects) such as the Tāraṇa Svāmī Panth, the Gumāna Panth and the Totā Panth. Many Jains in the USA come from these various sub-sects and put their individual and sectarian efforts into the processes of the negotiations though the sub-sectarian attitudes vary in many aspects such as rituals, visual and doctrinal. The following discussion presents multifaceted features of the Jain divisions. I will elaborate on attributes of the sub-sects.

Murtīpūjak/ Derāvāsī. The Murtīpūjaks (image worshippers) in contrast to the iconoclastic Sthānakvāsī and Terāpanthīs according to Cort (2001) are "numerically dominant section of Śvetāmbars" (42). Jains from this sect venerate images of Jinas in the temple and perform rituals of püja and darśan at the derāsar (Jain temple). The basic element of lay Murtīpujak Jains is the worship of the Jinas through rituals directed 
towards icons in the derāsar. The Murtīpūjaks mendicants are subdivided into six independent gacchs (groups) which literally means those who travel together. The gaccha as organizational units gradually supplanted four kulas (lineages) in the first several centuries of the second millennium CE (Cort 2001: 42). The Murtīpūjak gacchs are the Tapā, Añcal, Khatar, Paican, Vimala, Pārśvacandra and Tristuti.

Sthānakvāsī. Sthānakvāsī sect is the iconoclastic tradition of Jainism and rejects image worshiping. Cort (2001) points out that the Śvetāmbar Jains have undergone further division. The Sthānakvāsī sect gradually separated from the other Śvetāmbaras between mid-fifteenth and early seventeenth centuries CE. The Sthānakvāsīs do not only reject idolatry or image-worship as a part of Jain ritual culture but propagate reformation which involves a thorough refutation of images and idols. Sthānakvāsī mendicants always wear a muhpattī, a cloth over the mouth (41). The Sthānakvāsī tradition holds that the sect initiated as a reformation movement by the layman Lonka Śāh in Ahmedabad in response to perceive negligence in contemporary mendicant practice and in disagreement with the concept of worshiping images of the Jinas. This new movement eventually became the Sthānakvāsī in contrast to the temple-dwelling and image worshipping (Flugel 2006 and Dundas 2002). Humphrey and Laidlaw (1994) note that Sthānakvāsī teachers emphasize the efficacy of jap (ritual recitation of prayers and formulas such as the navakāra mantra. For Sthānakvāsī Jains, upāśray ${ }^{10}$ (empty building) is the place for religious activities that involve interactions with mendicants through either listening to sermons or participation in meditation or prayers rituals performed communally on a periodic, calendrical basis.

\footnotetext{
${ }^{10}$ Upāśray is a largely empty building, sometimes of two stories, with a central open hall used for sermons, and large collective rituals, and several smaller side rooms where mendicants can stay, study and eat in privacy (Cort 2001: 48).
} 
Further, the Sthānakvāsī mendicants are divided into twenty six monastic orders according to the regional affiliation, doctrinal schools and lineage descending (Flugel 2006: 325).

Terāpanthīs (Śvetāmbara Terāpanth). The Terāpanth (path of thirteen) is a split off from the Sthānakvāsīs under the mendicant Bhīkhanjī in 1760, over disagreement about mendicant and lay community conducts. According to Bhīkhanjī’s doctrine, giving assistance to any living beings other than mendicants is pointless from a religious perspective (Vallely 2002). Flügel (2006) points out that the Terāpanth is governed autocratically by a single religious leader ( $\bar{a} c \bar{a} r y a)$ who is invested with the constitutional power to make decisions for the mendicants and lay community members. It is a strongly aniconic tradition and stresses thirteen religious principles, namely, five great vows, five regulations and three restraints. The majorities of the Terāpanthī Jains are from Rajasthan, and come from merchant families of Bīsā Osvāl caste, who are part of Mārvāṛi community (Wiley 2009: 216).

The Digambara subsects. Bīsāpanthīs (path of twenty) accepts the authority of bhațtârakas and Terāpanthīs (path of thirteen) do not accept. Terāpanthīs sect of the Digambara tradition practice image worshiping in contrast to the Terāpanthīs of the Śvetāmbara sect. The Digambara Terāpanth was originally a tradition led by the lay community and not mendicants and it emerged in North India in protest against the lax and ostentatious conduct of contemporary Bīsāpanthīs (Flügel 2006:339) Moverover, Terāpanthīs practice dry pūjō and follows doctrine of Âcārya Kunda Kunda. Bīsāpanthīs supports bhațtârakas and practice $p \bar{u} j \bar{a}$ with flowers and fruits. Flügel also mentions that The Digambar Terāpanthīs Jains are in Rajasthan, Maharastra, and Uttar Pradesh states of 
India, while, Bīsāpanthīs dominate in Maharastra, Karnataka, Kerala and Tamil Nadu states in India. Flügel particularly points out the Digambar's identity resulted in the dominance of caste and communities (samāj) in North and South India due to the lack of inspirational religious leaders (2006: 342).

Śrimad Rājcandra Panth and Kānjī Svāmī Panth. Śrimad Rājcandra, a Jain saint from Gujarat, India lived during 1867-1901 CE and preached the path of spiritual liberation. Rājcandra's interpretation of Jainism is summed up in a short treatise called 'Attainment of the Soul' written in 1896 CE. According to Dundas (2002) Rājcandra's focus was more on spiritual development and enlightenment. He describes Rājcandra's philosophical stand as "He subscribed to the view that Jainism had gone into decline as a result of preoccupation with sectarianism and rituals which were, he claimed, sterile and divorced from any understanding of the spiritual teachings of religion” (263). Flügel (2006) mentions Rājcandra as “anti-sectarian”, and adds, “Śrimad Rājcandra movement has a multifarious organizational structure. It has no central, authoritative spiritual council or administrative body to which all Śrimad Rājcandra's followers are accountable... All Jains who are followers of Śrimad Rājcandra also venerate the Jinas to whom they offer appropriate ritual attention” (241-242). Majority of Śrimad Rājcandra's followers are Gujarati, however, Śrimad Rājcandra centers (āśram) are found in India, East Africa, and North America.

Kānjī Svāmī Panth started in Gujarat, India in 1934 CE as a neo-Digambar tradition Kānjī Svāmī. Kānjī Svāmī was a Sthānakvāsīs monk who was highly inspired by Ācārya Kunda Kunda's writings on the realization of the nature of the innate - pure soul. Kānjī Svāmī emphasized on the higler level of truth. He did not reject the worship images 
of the Jinas but stressed upon the internal transformation of soul. (Wiley 2006: 117). Kānjī Svāmī established the Digambara Jaina Svādhyāya Mandira in 1937 which houses Samayasāra in the main temple. Kānjī Svāmī Panth does not associate any mendicant lineage but it has attracted other Digambara sects and Sthānakvāsī community and non-Jain community as well.

\section{Jains: Sectarian and other Identity Markers}

Jains are associated with many other identity markers in addition to the sectarian identities. The diverse socio-cultural fabric of India is also visible in the Jain communities I studied in the USA. These identities reflect a multitude of collective identity markers such as castes (jāti/jñāti), languages, cultural backgrounds, and geographical affiliations. The Jains caste system is much similar to the caste system found in the Hindu society in India. The caste system among the Jains is a social institution and practice observed by them. Several social groupings of the Jains spread throughout India as a result of the caste system among the Jains. Cort (2001) points out that there are references of caste found at the earliest level of Jainism and it is unlikely that Jains have been less caste-organized (57). Some Jain castes are Vāṇiyā (vaisyas the merchant or trader caste identity) and its sub-castes such as V̄̄sáa Śrīmāḹis, Daśā Śrīmāḹis, Vīśā Osvāḷ, Daśā Osvāḷs and etc.

Presence of various Jain castes throughout India is also state or city specific. For example, Jamanagar city has majority of Vīśā Osvāḷ and Vīśā Śrīmālīis; while, Patan city’s Jain community exhibits almost six castes; Osvāḷs and Śrīmāḷīs in Rajasthan Jaipur (Flügel 2006: 216, Cort 2001: 57 and Banks 1992: 44). Flügel discusses in detail about the Digambaras bhațtāraka's caste system among Jains. He mentions that the 
Digambaras bhațtāraka tradition, bhatțārakas and their disciples were associated with thirty-one jātis in North India between the thirteenth and ninetieth centuries. He points out the presence of impoverished agricultural Digambara castes such as Bogāras, Cathurthas and others in northern Karnataka and southern Maharashtra were present during 1920s with a re-establishment of organized sainghas. Moreover, he mentions that "the exclusivist orientation of the bhattârakas towards castes which they dominated and to the property of their sangha proved to be a major obstacle to the ambitions of Jain communalists to unify the Jain community on a national platform during the years of the freedom struggle in the nineteenth and twentieth centuries” (2006: 346).

Cort (2001) asserts that caste distinctions among Jains are important for social identity; however, the differences do not essentially signify religious dissimilarities. Even though the caste serves as a social identity marker, but its impact is visible in case of social interactions. He mentions Bhāvsārs, Ramīs and Vaṇiyās castes in Patan. He points out that sectarian affiliations along with differences in caste create a greater combined sense of otherness. He mentions the case of Patan, in which the Sthānakvāsīs and Terāpanthīs pay respect by visiting each other's religious places often as required on special occasions, however, he points out that "on the level of daily interactions, the Terāpanthīs and the Sthānakvāsīs are both 'other' in terms of the Patan Murtīpūjak Jain self-definition” (60).

Along with the caste and sectarian affiliations, the Jains have different geographical affiliations, lingual grouping and cultural background. Hence, they speak different Indian languages or dialects, for example, Gujarati, Marathi, Marvadi and etc. The Jains with various lingual orientations use religious-ritual literature, such as 
recitation of prayers as per to their native or spoken languages. Kelting (2001) observes cultural and lingual orientations and affiliations of the Jains during her fieldwork. Some of her observations include the distinct variations in use of language at the religious practices and cultural differences they follow at social level. For example, she mentions that as the children of Jains in Pune go to the Marathi medium schools, they use Marathi script for the recitation of the stavan (Jain prayer). Moreover, she also marked the cultural difference between Marathi Jains and Gujarati Jains. She observes how Jains do form one particular culture holds opinion for the other. She cites her fieldwork experience conducted in Maharasthra and writes "Although there were both Gujarati and Marvadi Jains at the Ajitnāth Temple, these groups had an uneasy relationship in most of the city, where they have divided into separate identities when building temples and supporting mendicant lineage” (12). She adds, "The stereotype produced by both men and women focused on the role and expectations of women in the other group. Gujarati Jains often commented in casual conversation that the Marvadi Jains were conservative...Marvadi Jains spoke generally of the low level of propriety and honor in the Gujarati Community” (12).

Cort (2001) also points out the fabric of the diversity among the Jains in their identity markers and the distinctiveness among the Jains according to the diversity as:

Different Śvetāmbara Murtīpūjak Jain communities, whether in Bombay, Gujarat or Marwar, do not exhibit striking dissimilarities in the values and ideologies expressed in and through annual festivals, asceticism, lay-mendicant interactions, and temple rituals. There are important regional differences in the cultural styles through which these values are expressed, and the extent to which different values are emphasized, but the values are largely the same. This is not the case, however, for history and social structures, as these are regionally much more distinctive (31). 
The above discussed matters elaborate on the presentence of rich and complex identity markers are among the Jains and the ways such identity markers impact interaction (or less interaction) among the Jains. These identity markers are also present in the diaspora Jains in the USA. However, I will argue that for the Jains in the USA, unity precedes the division of identities through the negotiations in the social and religious spheres of their lives, in the chapters that follow.

\section{'Jain' identity in India and its Significance to the Diaspora Jains in the USA}

I find important to discuss the development of the 'Jain' identity in India as it significantly supports my analyses and arguments on the Jains' formation of a common identity in the USA. I begin with presenting a brief overview of the demographical trends of the Jains in modern India. Flügel (2006) points out that until 1881 no studies of the demographic trends in Jain monasticism were available, only, general census data of the Jain lay community was obtainable. The modern construction of Jainism as an independent religion initiated when the category of 'Jain' was included in the questionnaire of the Census of India in 1881. However, it is interesting to mention here in the words of Flügel that, "the desire of educated Jain elite to establish a clear-cut boundary between 'Jainism' and 'Hinduism', in the census itself and many Jains continued to refer to themselves as Hindu" (2006: 313). In response to the low turnout in the Census of 1881, reform oriented Jains became highly conscious about the problem of communal self-objectification and became active towards the sense of communal selfrepresentation. At the outset of the twentieth century, in order to identify as an important independent community, the Jains even designed a petition which encouraged community members to return as 'Jains' and not as 'Hindu.' By the time, unsettled debates among 
Jain community members, specifically laity groups in India, remained ambiguous about their social identity. In support of this discussion, Flügel (2006) emphasizes that, "The debate on whether Jains are culturally 'Hindus' or a 'minority community' wages unabated within the community. Thus far (at the turn of the twentieth century), Jain communalists have failed to establish the Jains 'as a separate social group' against the opposition of many Śvetāmbara ācāryas" (314). Two rounds by the census of India in 1991 and 2001 officially generated figures of Jain population in India. In the 1991 census, Jains were counted as 3,352,706, that is 0.4 percent of the Indian population while the census of 2001 produced the figure of 4,225,053, which is again 0.4 percent of the Indian population. ${ }^{11}$ Recent figures collected by the census in India are for 2011. According to the 2011 census of the demographical data of Jain population, ${ }^{12}$ total population of Jains in India is $4,451,753$, which is 0.37 percent of the total population of India. Moreover, according to the 2011 census in India, the Jain population lives in 34 out of 35 states and union territories of India and majority lives in states such as Maharashtra, Rajasthan, Gujarat and Madhya Pradesh. Certainly, this makes Jains to be in a small religious community in India.

It can be observed from the above mentioned data and scholarly analyses that Jains in India constitute a minority community. Moreover, the Jains have been pursuing social and religious exercises to identify and establish a separate Jain identity among the majority Hindus in India. In the case of the Jains in the USA, I note that they share the similar context as they have (had) in India. They remain a minority among the other

\footnotetext{
${ }^{11}$ www.censusindia.net; http://censusindia.gov.in/ and see Perter Fugel (2006:314).

${ }^{12} \mathrm{C}-1$ annexure - 2011 details of sects/religions clubbed under specific religious community obtained from http://censusindia.gov.in/
} 
Indian diasporas and also host communities in the USA. However, based on my study of the Jain community members' interviews and my observations, I will argue in chapter 4 that the Jains in the USA have been successful in acknowledging themselves for forming a separate Jain identity in the host country. Moreover, I will explore and evaluate the needs, explanations and methods the Jains have considered towards the formation of a common Jain identity in their diasporic context.

\section{Jainism's Status as 'Minority Religion'}

In light of Jainism's religious distinctive identity, Jain community members' demand for Jainism's status to be recognized as a religious minority is nearly a century old struggle. Dundas argues that it was seen as controversial for many in articulating Jain identity different than Hindus in India (2002: 6). It is important to mention here that Jains went through a struggle to establish themselves as an exclusive religious identity within the constitutional structure of India. Many chronological events during pre-independence and post-independence period in India indicate that the Jain community pursued many selfconscious efforts to be identified as a separate and distinct religion other than Hinduism and Buddhism. Indian constitutional clarifications and amendments highlight shifts in the recognizing of Jains as a minority community and Jainism as an independent religion than Hinduism. For example, Article 25(2)(b) in The Constitution of India 1949 mentions that 'Hindu' or 'Hinduism' shall be construed including Sikh, Jain or Buddhist religion. Other important phase came in 1993 when the National Minorities Commission (India) arrived at the recommendation that the Jain community be declared as a minority religious community. However, there was no formal status as a minority religious community was assigned. In 2005, the Supreme Court of India declined granting Jains 
the status of a 'religious minority' throughout India but the Court left the respective states to decide on the minority status of Jain religion. 'Freedom of Religion Bill' in Gujarat was passed by the Gujarat state assembly in 2003 with an amendment in 2006 which under the amendment bill clubbed Jainism and Buddhism as denominations of Hinduism. However, The National Commission for Minorities (India) criticized the Gujarat Assembly's decision to club Jainism and Buddhism with Hinduism and eventually in 2007, finding it not in conformity with the concept of freedom of religion as embodied in Article 25 (1) of the Indian Constitution held Jainism as recognized as 'religion' rather than denominations of Hinduism.

In January 2014, the Government of India, as per Section 2(c) of the National Commission for Minorities (NCM) Act (NCM) of 1992 explicitly awarded the status of a minority religion to the Jain community in India and declared Jainism as a 'minority religion' by regarding Jainism as a distinct mode of life and 'culture' which is embedded with coherent and independent philosophy, doctrine, and ideology.

The question of Jainism's status as a minority religion in India is a matter that blends Jains demand and a constitutional issue; however, for the diaspora Jains in the USA, the matter of Jainism's status as a religious minority group is more of a socioreligious issue. In this regard, I evaluate the Jains' processes of sectarian negotiations as a result of their self (community)-developed consciousness to be recognized and established as a minority religious community among the other Indian diasporas and host community in the deterritorializated context. During my fieldwork, I got the sense of how the Jains see themselves as minority religious players in the USA. Having been identified as a part of other Indian religious groups throughout their history, the Jain migrants in the 
USA are seizing the opportunity to unite and form a community. They see this as a way of securing a status as a formal, common social and religious group in the USA.

\section{Jains in Diaspora, a Special Reference to the USA}

The literature on the Jain diaspora is still scanty. The little research done so far shows a need for a more comprehensive investigation. However, I will present discussions on the Jain diaspora from available literature. I would like to begin with mentioning a few events that brought attention to Jain diasporas and also non-Jains in the West towards Jainism. Vīracand Gāndhī’s speech at the first World Parliament of Religions in 1893 on Jainism marked a coherent display of the doctrinal and ethical perspectives on Jainism world outside India. Later in twentieth century, Citrabhānu, a Jain monk who travelled to the USA in 1971 became a facilitator to the modernized version of Jainism to the Jain diaspora community in the North America. L M Singhvi wrote 'The Jain Declaration on Nature' in 1990. This writing was officially included in the network on conservation and religion. The writing emphasized the Jaina perspectives on the ecological implications, basic teachings on nonviolence, interdependence, and equanimity. These references suggest an eclectic scope to describe basic details of the Jain diaspora in the USA. Jains, majority Gujarati and Panjabi Śvetāmbaras from the Osvāl and Śrīmālī castes began to migrate first to East Africa and later to Britain from the late 19th century onward (Flügel 2012: 976). Many Jains have migrated especially to the USA since the 1960's. The Jain diaspora community in the USA has today reached approximately 140,000 (Vekemans 2015).

The Jain diasporic phenomenon goes against the values of orthodox Jainism which work against the flow of globalization. The Jain stereological philosophy demands 
restraint in all spheres of action - mind, speech, and body; and explicitly discourages travel and expansion. However, Jains have migrated as trading communities and professionals to the USA and contributed to the land of settlement at global level (Flügel 2012).The research has shown how Jains settled abroad utilized common worship facilitates with Hindu, known as 'Hindu-Jain Temple’ during the 1980s. However, it cannot be inferred whether such an arrangement was comfortable for both diaspora communities (Long 2009). Wiley describes how Jains abroad are found in relatively small numbers and how most Jain temples in North America are shared by the entire Jain community (Wiley 2006). Another research shows that within the Jain diaspora, the absence of religious authorities has redirected emphasis from ritual to ethical practice, particularly among the younger generation (Evans 2012). The issue of absence of ascetic leadership is also discussed and has been linked with the decline of sectarian affiliation among second generation Jains, and how the first generation finds diaspora Jainism less authentic than the way it is practiced in India (Vallely 2002). The Jain diasporic phenomenon goes against the values of orthodox Jainism which work against the flow of globalization. The Jain stereological philosophy demands restraint in all spheres of action - mind, speech, and body; and explicitly discourages travel and expansion. However, Jains have migrated as trading communities and professionals to the USA and contributed to the land of settlement at global level (Flügel 2012).The research has also shown how Jains settled abroad utilized common worship facilitates with Hindu, known as 'Hindu-Jain Temple' during the 1980s. However, it cannot be inferred whether such an arrangement was comfortable for both diaspora communities (Long 2009). Wiley describes how Jains abroad are found in relatively small numbers and how most Jain 
temples in North America are shared by the entire Jain community (Wiley 2006).

Another research shows that within the Jain diaspora, the absence of religious authorities has redirected emphasis from ritual to ethical practice, particularly among the younger generation (Evans 2012). The issue of the absence of ascetic leadership is also discussed and has been linked with the decline of sectarian affiliation among second generation Jains, while other writers note how the first generation finds diaspora Jainism less authentic than the way it is practiced in India (Vallely 2002).

The Jain diaspora community in the USA has identified three challenges: 1) to establish an independent religious identity separate from other diaspora Indian Hindus; 2) to keep the religious tradition alive against the backdrop of the absence of religious authority figures; and 3) to create unity amid sectarian divisions. The Jain diaspora community, along with its sectarian diversity, has similar issues. Sectarian splits and caste differences as they exist in Jain tradition in India are also an integral part of Jain diaspora community. This situation offer crucial leads in this study. My work deals with similar issues, like, challenges experienced by the Jain diaspora in context of the sectarian negotiations. Moreover, my study extends its scope by studying the sectarian negotiations among the Jain diaspora in the USA; and how it has resulted in the invention of a new form of Jainism.

\section{Conclusion}

This discussion offers support for my research in various ways. First, I argue that the accounts on the development of a Jain identity in the history of India demonstrate that the Jains have been involved in an age long struggle to achieve an independent religious identity among the majority Hindus and other religions in their own homeland - India. I 
discussed the different phases of the active and conscious struggle of the Jains to be identified as independent religious and communal identity, mostly 'other’ than Hindu. I argue in this study that the ongoing project by the Jain migrants in the USA to be recognized as distinctive religion and community is simply an extension of the struggles in the past. The second argument I present here is based on the sectarian profiles of the Jains. The Jains in India represent a very rich diversity of sectarian attitudes. However, they have remained to be in very small numbers. They maintain sectarian features and demonstrate few attempts to interact with other sects within Jainism. With regards to the matter of sectarian identities, the Jains in India also identify with other identity markers such as caste, language, cultural background, and geographical affiliations. All of these identity markers are taken in full considerations by the Jains as they interact among the larger Jain community. Caste, geographical affiliations, language and cultural background have remained intact in the case of the Jains in India. Moreover, the sectarian attitudes and other identity markers as seen in the above discussion exhibit rivalry and conflicts within the Jain communities in India at religious and social spheres. From this point, my research departs to new arguments. My research demonstrates that the Jain diaspora community in the USA reflects the sectarian diversity along with other identity markers of the Jain communities in India. However, the differences and diversity within the Jain diaspora in the USA are managed the sectarian negotiations. Not only have the Jains in the diasporic context managed to attain a common assent and accord at religious and social levels, through the sectarian negations, they have created a new tradition and constructed a new form of Jainism. Among the Indian diaspora, the Jain diaspora is also a minority religious community in the USA. Yet although it is a religious minority, the Jain 
diaspora has not received as much scholarly attention as larger Diasporas. My research presents some particular developments within the Jain diaspora in the USA that addresses specific sociocultural and anthropological question to enhance our understandings. Also, a potential contribution of the studying the Jain diaspora also lies in how it offers an opportunity to study how small diaspora communities in the USA thrive. For example what strategies do they use to survive as a diaspora? 


\section{CHAPTER 4}

\section{Coming Together: the Inception and Development of the Sectarian Negotiations among the Jains in the USA}

\section{Introduction}

In this chapter, I address the following questions: what are the characteristics of the sectarian negotiations in the Jain diaspora? What forces pushed the Jains to initiate these negotiations? How are the Jain community members experiencing it and how do they talk about this experience? In what contexts are these negotiations played out? In response to these questions, I argue the quest to create and perform a common Jain identity pushed the Jain actors to initiate these negotiations. The diasporic context gave birth to this quest. The diaspora has made it necessary for this community to establish a distinct Indian identity, which is based on the Jain. They see this project as crucial for their survival as a group because, as Jains from Indian they are a small segment of the Indian diaspora and must come together. Sensing the potential of sectarian differences to undermine the role of Jainism as an integrative symbol for the small community, they initiate the negotiations so that Jains will look beyond sectarian differences. What we see here then is the coming together of sociology and religion - the new social contexts of Jains in the USA generated needs, and the reconfiguration of the Jain religion is how they are responding to these needs.

\section{Sectarian Negotiations}

I use the expression sectarian negotiations in this study to refer to the formation of common formal Jain communities, the building of common Jain centers (temples) which are shared by all the sects. The expression also refers to the designing of an inclusive 
hybrid ritual and visual culture, the organizing of pāthaśālās (religious teaching programs), and the emergence of a common assent and accord for doctrinal and philosophical differences in Jainism. They captured their understandings of the negotiations and the expected goals in expressions such as "we are together" "we are just Jains", and "we are one community."

Since my research focuses on two major aspects of this process: the sectarian negotiations and resulting invented Jain tradition among the Jain diaspora community in the USA, it is imperative to begin by understating the foundation of the negotiations from the sectarian and the community levels. I note however, that these processes play out at all the levels and spheres of the Jain diasporic religious experience, that is, individual, ritual-visual culture, and doctrinal and philosophical, as the chapters that follow will demonstrate. Though I have specified three distinct levels and spheres of negotiations in earlier chapter; I observed that the levels and spheres are interconnected, overlap and merge with one another. This chapter offers a discussion of the sectarian negotiations and the new form of Jainism emerging from it. I offer an analytical account of the processes and effects of the negotiations among the Jain diaspora at sectarian and community level. The discussion in the chapter provides a window into the diasporic Jain community members' perceptions and experiences about the sectarian negotiations in the USA. Moreover, the chapter presents the narratives by the diaspora Jains that describe not only the strategies they have developed and efforts they are employing in maintaining the negotiations, but the benefits that accrue to the process. The basis of the discussion is the interviews and my observations during the fieldwork at the four Jain temples (centers). 
Figure 6 shows a group of Jains (of all the sects) together at the Jain temple of South Florida.

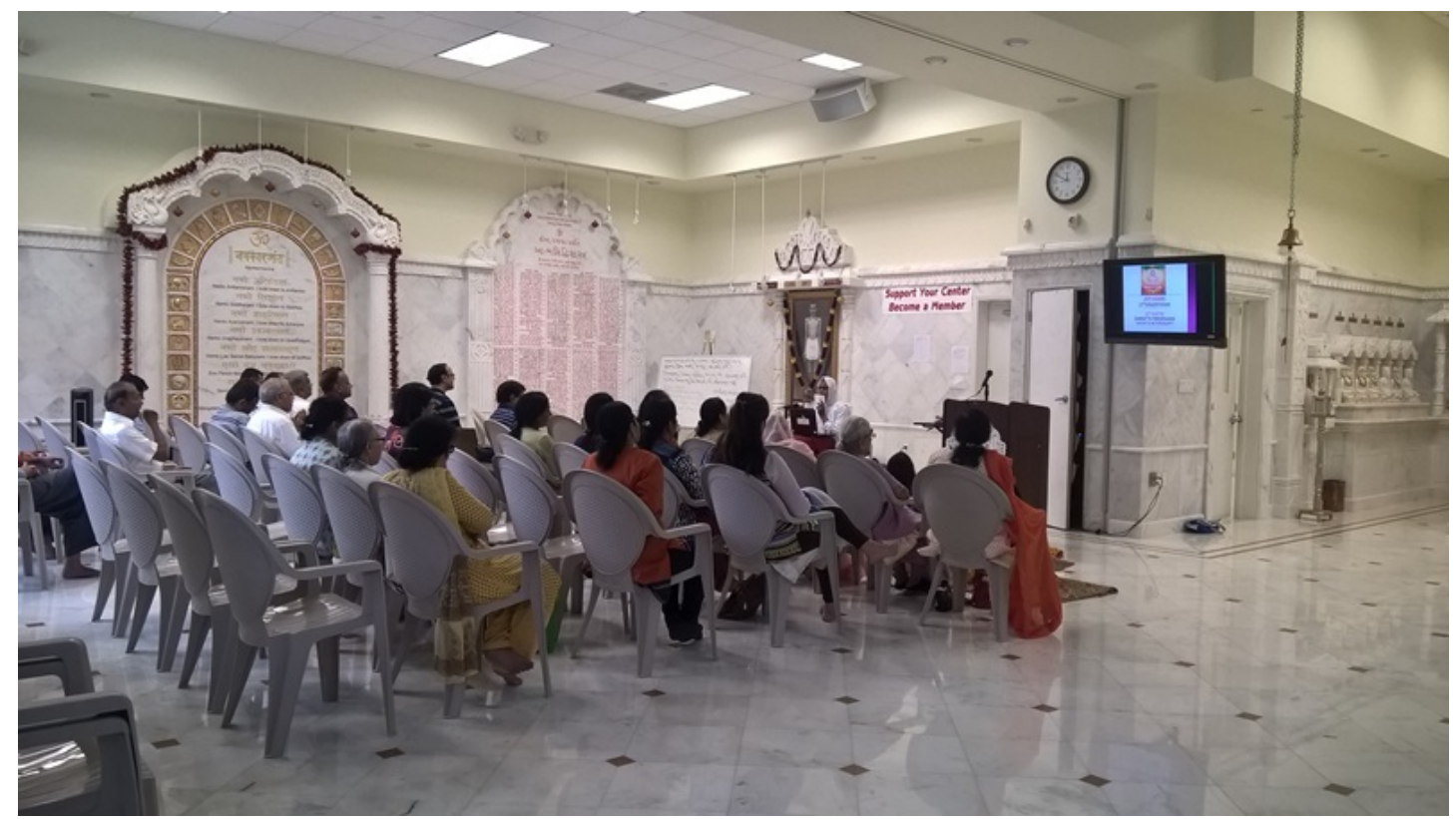

Figure 6. The Jain community members attending a lecture by Samạ̣i Shukla Pragya at Jain Center of South Florida

\section{“I Feel Stronger, United; I Feel Pride”: Coming Together - the Creation of the}

\section{Sectarian Negotiations}

“I feel stronger, united; I feel pride” were the words of Riddhi Shah, a young lay Jain female worshipper among the group of five I interacted with at the Jain temple in Chicago in June 2016. Riddhi Shah could not even wait to express herself as I asked her to share her thoughts on the sectarian negotiations and formation of a common, formal Jain community in the USA. Riddhi Shah belongs to the Śvetāmbara Sthānakvāsī sect; grew up in India and has been living in Chicago for more than fifteen years now. It was a group interview and we were sharing a table at lunch around $1 \mathrm{pm}$ in the large hall of the Jain temple in Chicago. More four Jain lay women joined Riddhi in the group interview. 
Nilam Shah, Janki Jain, Shila Shah and Tara Kamdar who belong to different sects, age groups, lingual and geographical background in were the other Jain lay women in the group and they all agreed to what Riddhi Shah asserted as a reply to my first question on the sectarian negotiations among the diaspora Jains. I could see the enthusiasm and joy on their faces as they expressed their views about the negotiations. I observed that their support for the concept of the sectarian interactions and negotiations among the Jains affiliated with the temple in Chicago was affirmative and confident. As some of them reflected deeper, they mentioned the benefits of forming a common Jain community in Chicago. For them, coming together means "more stuff to do.” I was excited to know about what they meant by “more stuff to do!” Therefore, I asked them to elaborate and they explained, "More stuff to do mean the possibilities to carry out various social and religious activities together as a community and in a united way."

After I asked a couple of more questions, the interview turned into a group discussion among the five women. I became a listener. However, I was happy that their guards were down and they were very comfortable discussing their perspectives on the presence of various sects at the same place. I believe it was the first time they had the opportunity to reflect on their experiences as a united group of Jains in the USA. As the discussion went on I threw some more sequential questions in. I asked, "what brings you to come together to build a common, formal Jain community in Chicago, USA?” Invariably, their replies unveiled an interesting concept - "motivation”. One woman said the presence of a larger Jain community at one common place (Jain center/temple) motivates them to come together. Another woman said the pleasure of meeting other Jains of different identities motivated them to visit the temple frequently. Underscoring 
these responses is a crucial theme-a sense of the need to form a Jain community and generate a feeling of being united. As the discussion proceeded, Riddhi paused briefly and said in an afterthought "I have grown up in India and I have seen two (Jain) sects bearing differences and fighting.” Although she remained silent after the statement I knew she was drawing my attention to a contrasting situation in India, emphasizing how the quest to depart from this situation was also a strong motivation. .

I take my interaction with Riddhi Shah and her fellow Jain lay women as a point of departure in my discussion on the sectarian negotiations in the diasporic Jain community and the factors that initiated the interactions and what the members of the community hope to gain from it. I argue that the sectarian negotiations are social phenomena and the result of religion's effect on society and society’s influence on religion. I build on Émile Durkheim’s (1995:9) functional approach to religion as theoretical framework to analyze the origins of the sectarian negotiations among the diaspora Jains in land of settlement, and its use as a method of constructing social unity between different sects and identities. I particularly refer to Durkheim’s idea of religion as a functional source of social cohesion and as continuation of society. The notion of the sectarian negotiations, essentially expressed in terms such as forming a common Jain community, performing rituals together and developing accordance on doctrinal matters uphold illustrates Durkheim’s concept of religious representations as collective representations that express collective realities. Jainism, in this regard functions as the glue the diaspora Jains use in achieving social solidarity through their practice of sectarian negotiations. I will mention a couple of more interviews and my observations of the fieldwork to bolster my argument. 
The Jain temple, the Jain Center of South Florida, houses a relatively small Jain community of around 100 to150 families. I interviewed a senior member of the community, a retired bank manager from India who looked very poised in his attitude. Having spent a significant portion of his life in India, he now lives with his children and grandchildren in Weston. He regularly visits the Jain temple every Sunday and on special events. He described the importance of the negotiations in terms of its ability to foster the Jain community's mutual support through the performance of social and religious activities. He mentioned how he has been observing the sectarian negotiations among the Jains at the Jain Center of South Florida closely for the last ten years and has come to believe that "the environment is better here than in India, specifically in terms of help and support the Jains receive from one another." He added "We all eagerly wait for the Sundays to gather at the temple." I interpret his stress on the word "gather" as an expression of the communal solidarity that accrues to the sectarian negotiations within the Jain community members.

The negotiations among the Jains I observed were not just restricted to interactions between the sects and among the Jains with various identities. It extends to the point where the Jains have distanced the difference. My observation is supported by an assertion a Jain member from the Jain community at Chicago made very confidently stating that “We don’t carry any difference and therefore, (the Jain) children even don't learn to keep any differences.” This underscores how the Jain community in the USA sees looking beyond sectarian differences as part of a conscious effort to come together in order to achieve social unity and passing on this culture of existing with difference to 
their children, the future generation. Figure 7 shows some playful time for the children at the temple.

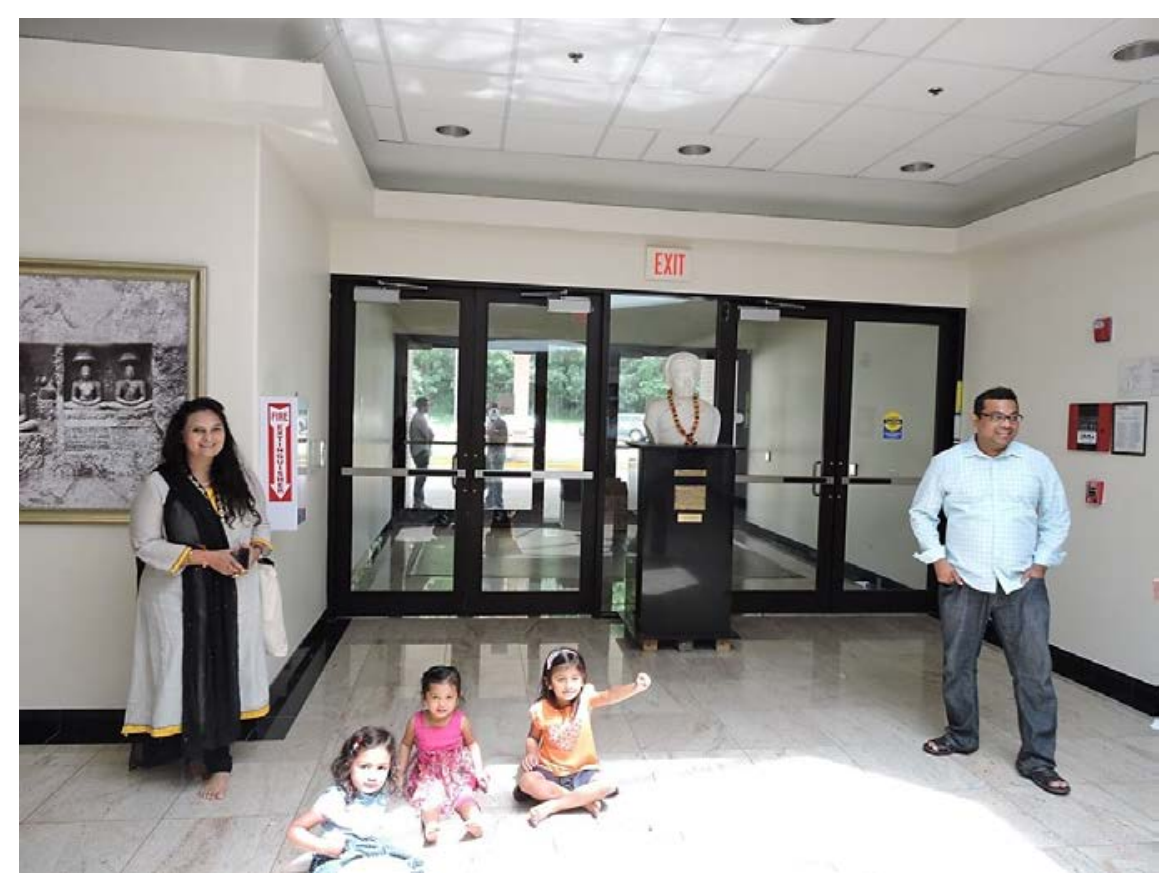

Figure 7. Children enjoying being at the Jain temple building, Jain Society of Metropolitan Chicago

I observed how sociological and religious forces interact to offer a conducive backdrop for the inception and development of the negotiations among the Jains. The diasporic context is an important social factor, which has affected the formation of a common, formal Jain community. Before I proceed with the discussion, I must mention the relevance of my positionality as one who is part of this diasporic experience, to this discussion. It has been almost a year since I left my homeland. Each of the layers of my identity such as a Jain, a female, and a Gujarati has coalesced into one, as an Indian living on a foreign land, very far from home. The observations I made, the data I gathered, the interviews I conducted among the Jains in the USA demonstrate the feeling of being 
uprooted from the homeland. In other words, my position as a non-immigrant student in the USA helped me to relate to the diasporic experiences and mediations of the Jains I studied in the USA. A respondent whose narrative illustrates how the diasporic experience pushed the Jain community to develop sectarian negotiations is Rekha Shah, a doctor who has lived in Phoenix, USA since 1972. I met her at the Jain Center of Greater Phoenix in August 2016. We discussed many issues that day and continued our conversations on phone a week after our meeting in person. When I asked her the reason for coming together in the land of settlement, she pointed out two factors - "feeling of vacuum" and "sense of longing." She mentioned that coming to a foreign land makes us feel a vacuum and we long for a group in order to feel a sense of belonging to an identity. The identity she mentioned, I infer, is a reference to the replacement of the feeling of being uprooted. She made a point of emphasizing that "Here in the USA, it is the longing that helps us to come together.” Rekha Shah’s statement “...longing that helps us to come together" leads directly to how the effect the experience of feeling unmoored from one's own land is linked with the sectarian negotiation project the Jains have embarked on in the USA. Additionally, it can be inferred from Rekha Shah's diasporic experience that an array of notions of diaspora including the concepts such as dispersal from an original homeland which often brings about the sense of a collective memory about the homeland and a strong ethnic group consciousness (Cohen 2008), underscores the sectarian negotiations. The development of the sectarian negotiations also entails the bearing of the diaspora status of the Jains in the USA as a social form; as type of consciousness; and/or as a mode of cultural reproduction (Vertovec 2000: 142). These three depictions of diaspora play out very well in the Jain diaspora community in the 
USA. It is clear that the diasporic consciousness has affected the sectarian negotiations among the Jains. The argument of Alpa Shah (see Figure 8 below) a Sthānakvāsī lay woman who has lived in Phoenix, USA for the past twelve years adds a new twist to the reason the Jains had for creating a common Jain community. She said "belonging to a larger community of people who share a common culture gives support when we come to a non-Aryan land (other than Indian sub-continents).” She also alluded to the notion of adaptation to the contemporary diasporic setting when she added "there is nothing wrong in accepting our own people when we are already accepting the multicultural setting of the USA.” From my interactions and observations at the four different sites I studied it becomes clear that the diasporic context of the Jains in the USA have developed what Cohen (2008) has characterized as a sense of co-responsibility with co-ethnic members in the USA.

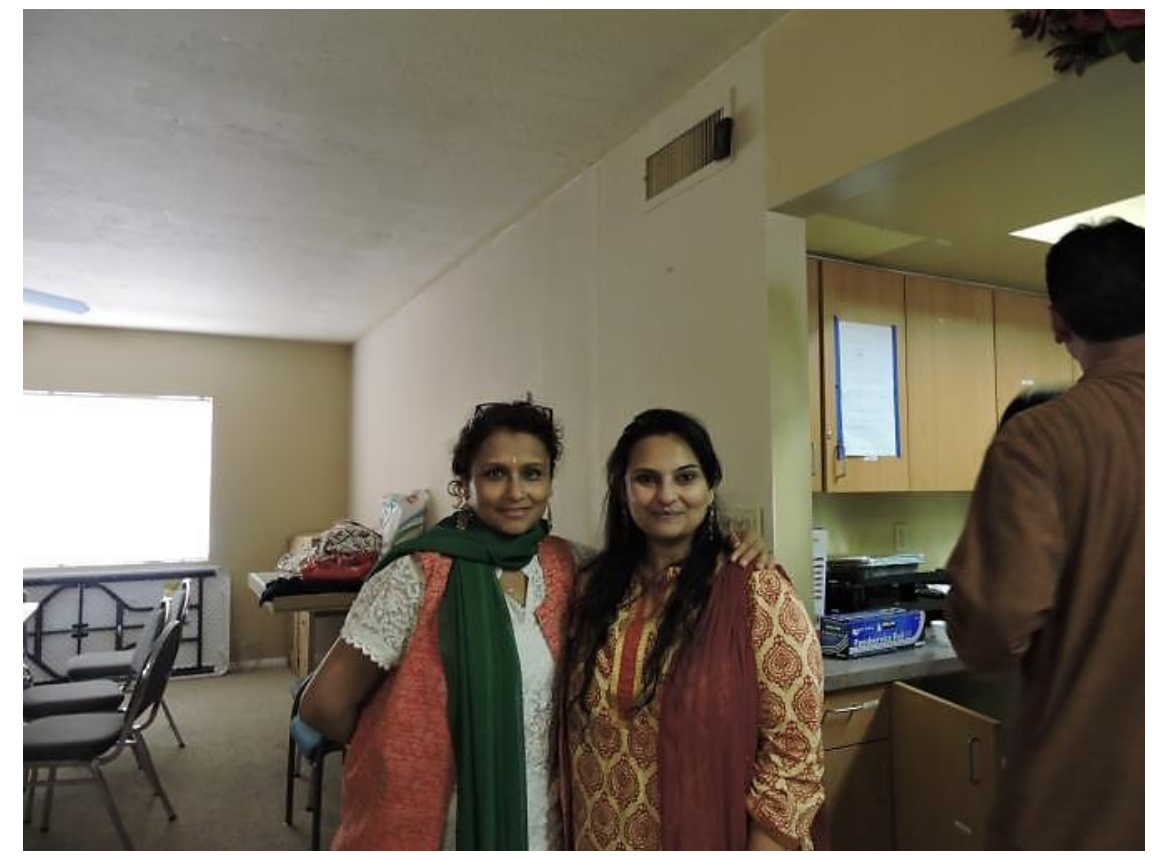

Figure 8. Alpa Shah, a Jain community member at the Jain temple, Phoenix and Myself 
Monil Soni, a young Jain is an engineer by profession. He visits the Jain Center of South Florida regularly. His interview was the shortest among all I had but his rationalization of the negotiations reveal how the diasporic situation of the Jains has pushed them to rethink some traditional Jain ways of doing things. He said "We come here only one day in the week, why to waste time in fighting over differences of opinions!” His straightforward justification of the concept of negotiations leads to James A. Beckford's (2003) social constructionist approach to religion. Beckford approaches religion sociologically as "modest” social constructionism (3). He explains further:

Only human beings construct, communicate, and negotiate shared meanings in the course of their social interactions with each other. For example, public order, disorder, panics, and confidence all emerge as the products of countless human interactions. Similarly, my main interest is in the social processes whereby the meaning of "religion" is continuously being intuited, asserted, doubted, challenged, rejected, substituted, re-cast, and so on, in social contexts (Beckford 2003:3).

Monil Soni’s view reflects Beckford’s (2003) social constructionist approach.

His views point to how members of diaspora Jain community in the USA have constructed their own meaning of reality in the setting of the diaspora. The sectarian negotiation among the Jains is a product of their interactions and the realization that some traditional attitudes are no longer tenable in their new situation as a diasporic group. This shared understanding is a product of their diasporic conditions. The Jain diaspora community members' roles as active agents in the processes of the negotiations and overlooking of the sectarian barriers are also clearly demonstrated here.

I observed during my several visits to the temples and my interactions with the community members that for the Jains, the decision of coming together is a result of constructed reality. I argue that several diasporic conditions such as necessity to survive 
in the land of settlement, inculcation of a sense of being a Jain in children, a need for secured support in any type of absurd experiences and the quest to fill the cultural void, have played major roles in pushing the Jains agenda to create a unified community.

The Jain diaspora community's conscious and effortful process towards the sectarian negotiations which overlooks the distinctions between all types of identity markers makes us see their form of Jainism as a form of invented tradition and leads us to the analytical framework of Hobsbawm's (1983). According to Hobsbawm, inventing traditions represent responses to novel situations even though the inventions can take the form of references to old situations (1983: 2). In this regard, the sectarian negotiations and its result, that is, the creation of formal, common Jain community is the invented tradition. Unity among the Jains at the levels of sectarian and other identities are more of the pragmatic phenomenon that entail accepting and abolishing the differences are sensibly and realistically adopted strategies also notes how new traditions are invented in situations where old traditions and their institutional carriers and promulgators no longer prove sufficiently adaptable and flexible. I refer this stance of Hobsbawm and claim that the sectarian negotiations are invented by the Jains in the USA because the diasporic settings and needs call for new ways of doings things.

Sociologists also examine the dynamics of social phenomena with the 'social movement' paradigm and contribute to understandings of what is peculiar to those forms of group behavior (Banks 1972). Heberle (1951) defines ‘social movement' as:

A specific kind of concerted-action groups; they last longer and are more integrated than mobs, masses and crowds, and yet are not organized like political clubs and other associations...Group consciousness, that it, a sense of belonging and of solidarity among members of a group, is essential for a social movement, although empirically it occurs in various degrees (439). 
Similarly, Banks (1972: 8) describes how we conventionally regard social movements as part of the subject-matter of collective behavior, but can also view them as an aspect of social change. Banks (1972: 15) identifies some social movement as ‘socially constructive', and differentiates them from the movements that are social responses to situations of stress. He identifies social innovation and invention of social technologies as features of a social movement. For Banks, social movements are resourced by collective behavior, are those processes which invent social technologies, and are regarded as the agents of social change. I argue that the sectarian negotiations among the Jain diaspora community represent a kind of social movement within the broader Jain community. This is to say that, the diaspora Jains have collectively invented their social technologies in a form of the sectarian negotiations, to distinguish themselves from the Jain communities in India, where rigid sectarian boundaries are maintained. The sectarian negotiations among the Jain diaspora community which results in an invented Jain tradition' emphasize the experiences and perceptions of the Jains in diasporic conditions, not what is considered to be traditional Jain practice. This demonstrates the agency of Jain actors in the USA diaspora in leading reforms within the tradition. It is however still not clear how these diasporic changes are affecting Jain religious practice in India.

\section{"We are Jains": in the Making of a (common) 'Jain' Identity in the USA} I have argued earlier in this chapter that the sectarian negotiations typical of Jainism in some temples in the USA is linked to the diasporic conditions of the Jain actors and aims to produce social unity. I will continue to assess the negotiations and formation of a common Jain community in the context of another prominent finding from the research, which is, the creation of a common 'Jain' identity. I contend that the sectarian 
negotiations among the Jains have been instrumental for them in the creating of a 'Jain' identity, a minority religious identity in the USA. I offered a gist of a background that mentioned a few events and efforts carried out by the Jains in India to establish an independent religious identity earlier in chapter 3 . This entails being recognized as having a separate religious status; from its larger co-religion, Hinduism. In keeping with this history the Jains in the USA also have aspirations towards being identified as 'Jains.' So far, very little research effort has been devoted to the study of diaspora Jains and their 'Jain' identity in the USA. My study intends to fill this gap and to show that the Jains, as an absolute religious minority in the USA aspire towards creating a unique, separate and independent identity from other Asian-Indian religious diasporas. In this regard, my research reveals that the sectarian negotiations have played a pivotal role in executing the process of making a common 'Jain' identity.

In offering a theoretical way to understand the link between the sectarian negotiations taking shape among the 'Jain' and the constructing of an identity as a diaspora religion in the USA I find it useful to build on Arjun Appadurai’s (1996) reformulation of the meaning and usage of culture in our increasingly globalizing world. In his exploration of anthropological conditions in the era of globalization Appadurai points to the need to link the process of naturalization and mobilization of group identity with globalization. Appadurai recasts culture as something that is “...not usefully regarded as a substance... but it better be regarded as the dimension of phenomena, a dimension that attends to situated and embodied difference" (1996: 12-13). He further adds that the word culture is close to the idea of ethnicity, and suggests that we must regard the cultural as those differences that either give expression to, or prepare the 
groundwork needed for the mobilization of group identities. In this context, Appadurai equates culture with ethnicity and makes it a basis for creating and performing group identity (1996). Furthermore, Appadurai notes that, "in our usage of culture we should not stress simply the possession of certain qualities (material, linguistic or territorial). Rather what we should emphasize is how "the consciousness of these attributes and their naturalization” are essential to group identity (1996: 13). Further, he links these dispositions to the contemporary era of "mediations", "migration or succession and globalization” (Appadurai 1996: 15-16). Appadura’s argument offers crucial leads in my theoretical exploration of the process of sectarian negotiation and identity creation among the Jain diaspora in the USA. Following Appadurai, I suggest in this study that we view the Jain diaspora in the USA as a distinct Indian ethnicity, with the Jain religion functioning as the basis of the difference of this ethnic group from other Indian diaspora communities. I argue that for the diaspora Jains in the USA, Jainism through the sectarian negotiations acts as a basis of a Jain culture which is the foundation for a common 'Jain' identity. Appadurai’s (1996: 12) adjectival use of ‘culture’ speaks to the Jain diaspora community's approach to constructing a Jain identity which is formulated upon the multisectarian approach to 'Jainism.' I contend that we must view Jainism as a process (not a thing) that is subject to periodic revisions, and Jains themselves as active agents in this revision.

I could observe and interpret the notion of a common Jain identity because I as a Jain had experienced the need and struggle to be recognized as 'Jain' and not as 'Hindu' in India. I was indeed a passive actor in experiencing the joy shared by the diaspora Jains' because of their accomplishment of attaining the 'Jain' identity in the land of 
settlement thorough the sectarian negotiations. In the discussion that follows I report the views of some the Jain respondents during my research on how they are constructing a Jain identity through sectarian negotiations and what this identity means to them.

Shilpa Mehta who I met at the temple in Chicago shared an interesting standpoint on a common 'Jain' identity. She has grown up in the USA, and she points out that she has never seen "the Indian version of sectarian Jainism." She added that "We all are happy that we are Jain. We are small in number here in the USA, so, what is the point of breaking us down more?" She continues "I have seen only the Chicago version - model of Jainism, I feel united here, together with others, so I never knew that there was any sectarian differences existing in Jainism.” Shilpa Mehta’s sense of being a Jain and sharing a common Jain identity in the USA is deeply rooted in the concept of a unified sectarian presence in the USA. She sees all Jains as one group because she has been oriented towards overlooking sectarian differences.

I contend that the sectarian negotiations significantly impute to Jainism a kind of 'culturalism.' Appadurai defines culturalism as, “a feature of movement involving identities consciously in making” (1996: 15). ‘Culturalism’ is frequently associated with extraterritorial histories and almost always with struggle for stronger recognition from existing nation-states or from various transnational bodies. Referencing the concept of culturalism, I ague that for the Jain diaspora community in the USA, the sectarian negotiation represents an ascertained effort of culturalism. My study demonstrates the process of the sectarian negotiations among the Jain diaspora community in the USA as a culturalist movement. I argue that the sectarian negotiations entail the creation of a common Jain identity in the USA. My study reveals how process of the sectarian 
negotiations among the Jain diaspora in the land of settlement is associated with a struggle for stronger recognition from the existing nation-states, the USA and also from various transnational bodies.

Following Cohen’s (2008) arguments, this study demonstrates that the process of the sectarian negotiations and creation of a new form of Jainism among the Jain diaspora community reveal the feature of a "strong ethnic group consciousness sustained over a long time” and based on "a sense of distinctiveness”, “a common history”, “the transmission of a common cultural and religious heritage" and "the belief in a common fate” (2008:17). These features of diasporic experiences are palpable in the process of the sectarian negotiations among the Jains in the USA. The research has shown how a strong ethnic group consciousness and a sense of distinctiveness functions as strong motivations for the Jain diaspora community in overlooking sectarian barriers and creating a new form of Jainism. Cohen points out that diaspora sometimes feature a troubled relationship with host societies, linked to a lack of acceptance or another calamity that might befall the group. My study reveals that the issue of acceptance and fear of calamity play out prominently in the forces that push the Jain diaspora community to overlook the sectarian differences (2008). It is also important to note that the Jain diaspora community also reflects what Cohen refers to as "a distinctive creative”, “enriching life in host countries”; with a "tolerance for pluralism”. Through sectarian negotiations the Jain diaspora community demonstrates inter-sectarian tolerance in the form of sectarian pluralism (2008:17).

My study reveals that the sectarian negotiations, as a process of culturalism is based on two major premises, first, to form a separate ‘diasporic identity’ amongst Indian 
diasporas, and second, to be recognized as a 'religious minority identity' in the USA. Many Jain parents informed me during the interviews and informational conversations at the temples that unity among the Jains, regardless of their various identity markers emphasizes on the common 'Jain' identity in the USA. For this matter, children also learn to be identified as Jains among the wider American society. I observed that the sectarian negotiations among the Jains in the USA enable the future generation to feel the sense of belonging to a common identity. Pankaj Modi, who belongs to the first generation of Jain diaspora, reflects upon the needs and benefits that the negotiations bring to the diaspora Jains in the land of settlement. Pankaj Modi, who has been living in Chicago since 1974, asserted "To bring the community together means that the younger generation get motivated to visit the temple.” He added "Kids are unaware of the differences, and unity among the Jains help preserve and carry on the culture.” I will like to stress here that the second generation parents and specifically the mothers who I met during my fieldwork seemed to be very comfortable with the concept of common, formal Jain community and emphasized how this was a crucial heritage for their children. According to many of my respondents, their children now introduce themselves as “Jain”, "Vegetarian” and "Indian.” These tri-level identity benefits them as if offers them an ethnic or cultural ground to stand on to assert themselves in the larger American society.

Ms. Sonal Mehta ${ }^{13}$, a gracious Jain lay woman, who also holds a prominent management position in the Jain Center at South Florida talked freely about the benefits of forming a common Jain community. She informed me that "It is easier for both parents

\footnotetext{
${ }^{13}$ Ms. Sonal Mehta is the present president, Jain Center of South Florida. When I interviewed her in 2016, she was the vice-president of the center.
} 
and children that they have a sense of common Jain identity. Kids don't know about the differences, they don't know what sects are, and we share a common identity.” The idea here is that a united Jain front facilitated by the community's de-emphasizing of sectarianism offers it a congenial context for generating a sense of oneness among members.

As the Jain diaspora community in the USA is establishing a sense of unity through the sectarian negotiations, the process reflects anthropology's commonplace concepts such as anti-essentialist, constructivist, and processual approach to ethnicity (Vertovec 2000, Baumann \& Sunier 1995). The Jains are demonstrating anti-essentialist and constructivist approaches in implementing the processes of sectarian negotiations and creating a new form of Jainism as the basis of a common 'Jain' identity. The sectarian negotiations among the diaspora Jains are not just limited to the religious-sectarian levels, they extend to the levels of other identity markers such as caste, language, ethnicity, geographical affiliations, and culture. In this connection the process resonates with the concept of diaspora as mode of cultural production (Vertovec 2000: 142). This allows me to argue that the diaspora Jains are deemphasizing individual or sectarian identities and creating a common 'Jain culture' in the form of the sectarian negotiations and the 'invented tradition.' This, I argue, is a process of a production of a common 'Jain culture', both, at social and religious levels. I find worth mentioning here that the Jain diaspora community as a religious minority in the USA, found it essential to be identified as 'Jains.' A need to be identified as 'Jains', and not as a sub-group of 'Hindu-Hinduism' within the Indian diasporas is being met by their process of the sectarian negotiations. 
It is important to note that, the sectarian negotiations among the diaspora Jains are not completely removing the sense of individual or sectarian identities, but, using the differences creatively in order to create a common culture. I use McCrone’s (1998) explanation for the integration processes across cultural and ethnic identity to explain my argument. McCrone asserts that the key point here is that there is no one-to-ones relationship between ethnicity and cultural identifiers (1998). What matters is which ones key actions regard as significant, for which purposes and under which conditions. He proliferates his idea as:

To the extent that actors use ethnic identities to categories themselves as others for purpose of integration, they form ethnic groups in this organizations sense...some cultural factors are used by the actors as signals and emblem of differences, others are ignored, and in some relationship radical differences are played down and denied (McCrone 1998: 28-29).

McCrone’s (1998) assertion advocates a relational and processual approach to ethnicity. That means a group's culture may change without removing the ethnic boundary and groups may become culturally more similar at the same time as the boundaries are strengthened (202-3). By considering the framework of diaspora as a concept of cultural production, I argue that the diasporic experiences of the Jain community are pushing such ignoring, reducing, and negotiating of cultural and religious identity markers in order to integrate.

Since I argue that the sectarian negotiation and 'invented tradition' are the two major findings of my research on the Jain diasporic experiences in the USA, Hall's (1990) ideas about the link between diaspora, ethnicity and identity are relevant here. According to Hall: 
Diaspora does not refer us to those scattered tribes whose identity can only be secured in relation to some sacred homeland to which they must at all costs return, even if it means pushing other peoples into the sea. This is the old, the imperializing, the hegemonizing form of 'ethnicity' ... The diaspora experience as I intend it here is defined not by essence or purity, but by the recognition of a necessary heterogeneity and diversity; by a conception of identity which lives with and through, not despite, difference; by hybridity. Diaspora identities are those which are constantly producing and reproducing themselves anew, through transformation and difference (1990: 235).

This assertion speaks largely to how the Jains in the USA play down the sectarian differences in order to produce a common identity.

Amita Jain, who has been living in New York for last thirty-five years and belongs to the Digambara sect said “Outsiders (any non-Jains) should not know that we belong to various sects.” There is an insider/outsider dynamics in identity creation in which insiders of a community care about how they are viewed by the world outside. Here Amita alludes to the importance of the Jain community demonstrating the strength of a common Jain identity to the outside world. For her, this necessitates the downplaying of sectarian differences as the emphasis on these differences might make the outsiders view the Jain community in the USA as internally weak.

Mr. Kapadia, a senior Jain community member and a Śvetāmbara Murtīpūjak who moved from Tampa has lived in Miami for three years. His daughter and son, both live in Miami. His profile becomes more interesting as he adds that his daughter is married to a Sthānakvāsī, a non-image worshiper sect of Jain tradition. His view shows how sectarian negotiations are important for the performance of identity. He stressed upon the cultural and social impacts of the negotiations and explained that the unity among the diaspora Jains at this temple means "no difference of opinion.” Additionally, for him, the unity is greatly helpful during social events such as marriage functions, birthdays and other 
contexts where the community performs its identity. Here we see how the strong sense of a common identify facilitates important social contact among members. Mr. Kapadia also sees co-ordination as the key to the success of the negotiations. In his words, "it is the coordination which binds everyone together in this community and at the same time, the negotiations at the religious level teach us to co-ordinate lives at the social level.” His views on the processes of the negotiations reflects the interplay of sociological and religious forces. Towards the end of my interaction with him, Mr. Kapadia remarked that "the negotiations among the Jains made them drop the emphasis of the sectarian and other identities and allows instilling in the children a culture of "We are Jains," echoing views expressed earlier by Jain female community members about how the creation of a common Jain identity was necessary for the transfer of the heritage to next generations..

The Jain community members’ narratives on sectarian negotiations which I have mentioned, especially Mr. Kapadia’s expression “We are Jains”, push me to ponder a point in this research. This is the idea that, for the Jains in the USA, there is a robust connection between Jainism, 'Jain’ identity and diaspora. As I discussed earlier in this chapter, Jainism plays a role in bringing all the sects together in unity. Nevertheless, the context of diaspora plays a major role in modeling the negotiations. Figures 9 and 10 show some of the Jains who spoke extensively during the interviews about the needs and effects of the sectarian negotiations and making of a common Jain identity. 


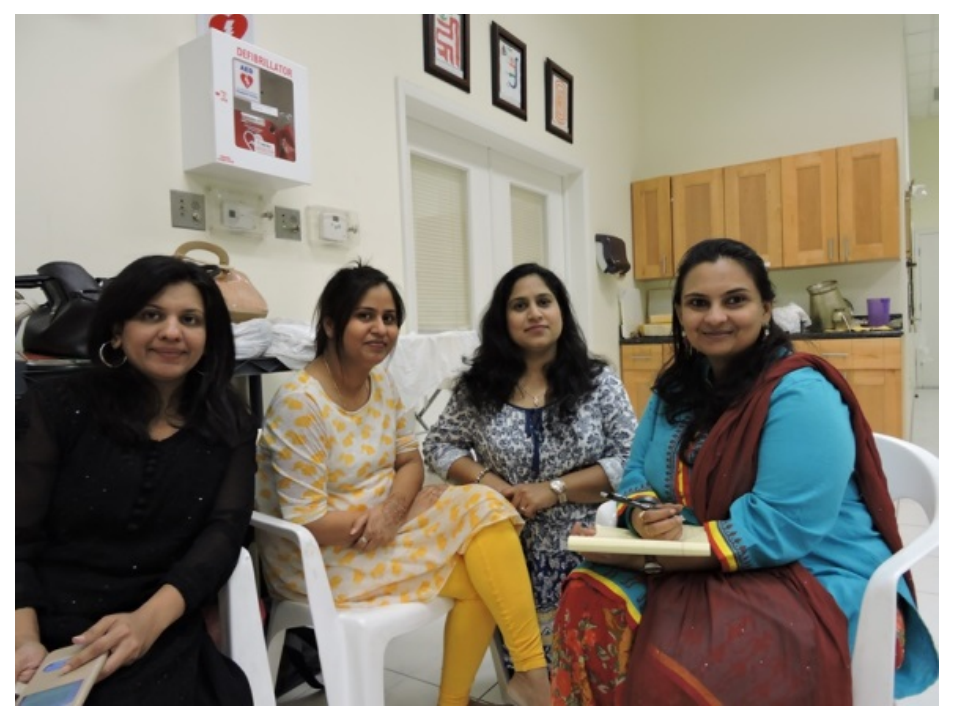

Figure 9. Interviewing Jain lay community members at Jain Center of South Florida

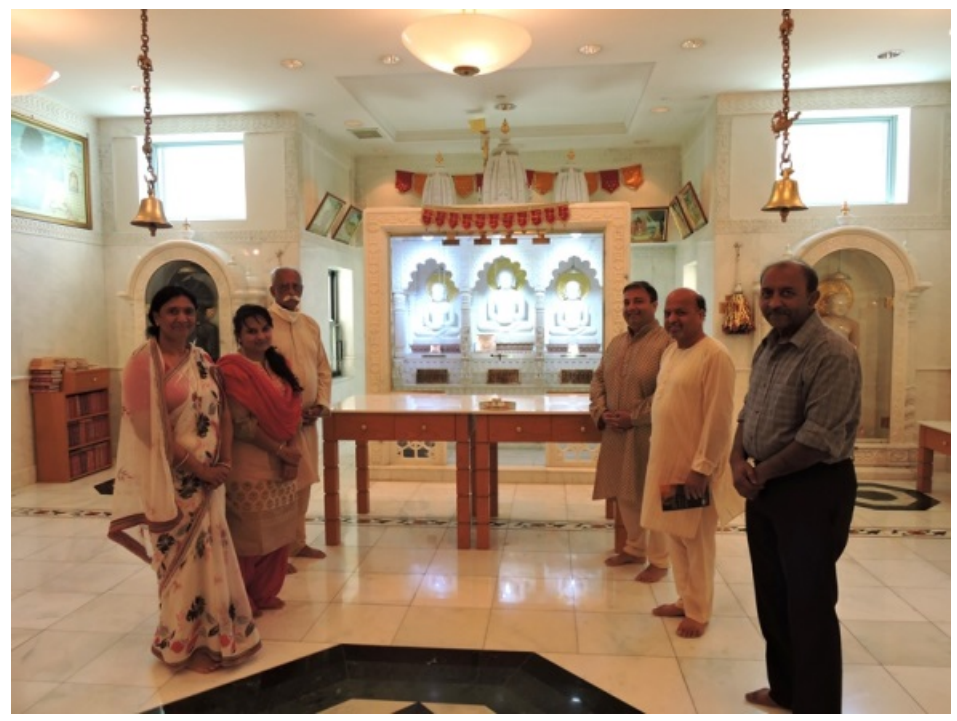

Figure 10. Some of the Jain community members who I interviewed at the Jain Temple, New York

It is very important to note at this point that the Jains in India continue to follow their sectarian identifiers and affiliations. The Jain diaspora community in the USA are different compared to the Jains in the homeland. These processes represent creative reproductions at the sociocultural and religious levels. Additionally, in keeping with 
Arjun Appadurai's (1996) concept of 'global ethnoscapes' the two phenomena among the diaspora Jains in the USA, that is, sectarian negotiations and the invention of Jainism, are attestations of changes. Appadurai describes how migrating groups "regroup in new locations, reconstruct their histories, and reconfigure their ethnic projects” (1996: 48). He further points out that "the landscape of group identity - ethnoscapes tend to reproduce, as groups are no longer tightly territorialized, spatially bounded, historically unselfconcious, or culturally homogeneous" (Appadurai 1996: 48). I argue that the sociocultural and religious changes among the diaspora Jains in the USA is a function of its deterritorialization. Moreover, the changes reflect the effects of the globalized setting of the USA. America is currently a meeting point of Jains from all walks of life and this coming together has necessitated the measures the community has embarked on to create a common Jain religious form with which all Jains can identify. I argue that the notion of 'global ethnoscapes' specifically relates to the diaspora Jain community's efforts to create a common ‘Jain’ identity.

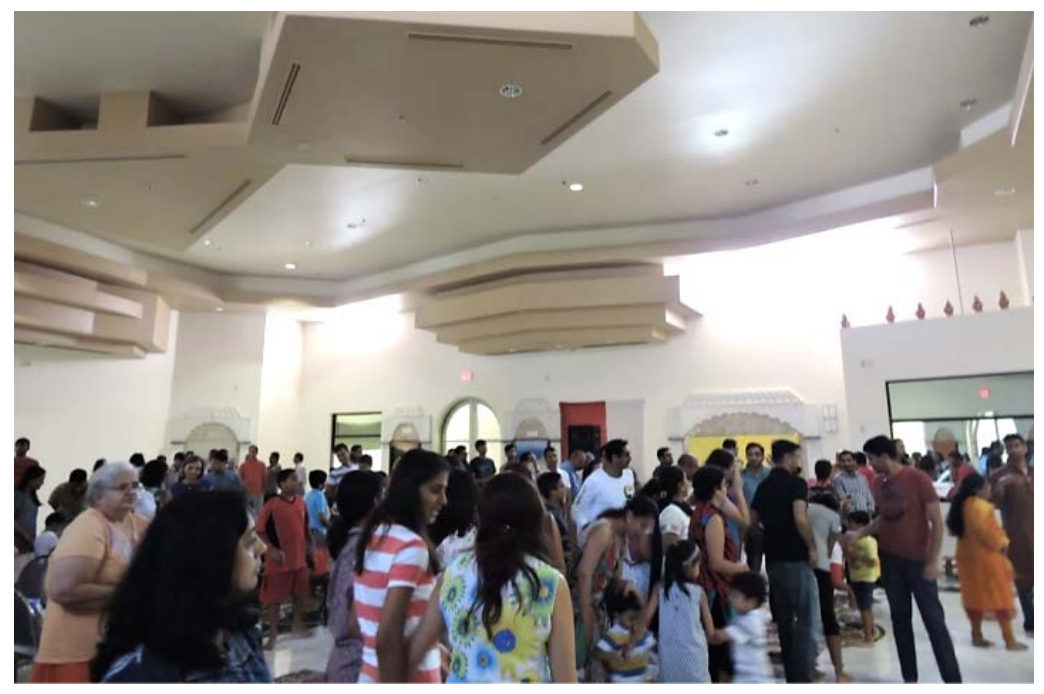

Figure 11. Jain community members at the Jain Center of Greater Phoenix 


\section{The Śvetāmbaras cook for the Digambaras: Living and Working towards the Negotiations}

Geertz’s (1973) example of ‘a mock sheep raid or wink’ speaks to what he describes as a “microscopically examined” research field (417). In this connection he advises researchers to be wary of superficial expressions or manifestations in the research field because "social actions are comments on more than themselves; that where an interpretation comes from does not determine where it can be impelled to go. Small facts speak to large issues, winks to epistemology, or sheep raids to revolution, because they are made to” (23). Following Geertz’s (1973) method of “microscopically examining” social actions in my research, I go beyond superficial demonstrations of the sectarian negotiations through activities at the temples I visited, to the deeper levels of expression. Let me begin with accounts of some events I observed during my visits. These events offer us opportunities to present thick descriptions of how the Jains in this study demonstrate the sectarian negotiations through activities they engage in. In other words, we catch a glimpse of them performing the new Jain identities they are constructing through their sectarian negotiations. They do not only describe these negotiations, they live the process.

It was 9:30 am on one Wednesday in the month of July, 2016 at the Jain Center of America, New York in Queens. A group of women from the Śvetāmbara sect was busy in the kitchen situated on the fourth floor of temple building. They were preparing food for about 50 to 60 people. At the same time on the second floor of the temple building another event was unfolding. The Digambaras were performing the püj $\bar{a}$. In what I would describe as a third event, I was busy taking pictures of the pūjja rituals, interacting 
with some senior members of the community, and listening to the recitations of the prayers. My positionality as a Śvetāmbara Sthānakvāsī was at play here. As a Jain naturally rituals attracted my attention constantly throughout my fieldwork at the four temples. I would even say my observations and interviews with the Jains were interactive and smooth because I was Jain. However, my knowledgebase of the various sects of Jainism expanded only after coming to the USA, and specifically due to the sectarian negotiations among the Jains. More importantly, by the time I was in the middle of my fieldwork, I had developed a special inclination towards the Digambara ritual culture.

These three events are interrelated for the reasons that each event offers a context for observing how the negotiations are carried out by the Jains across sects, caste, language and geographical backgrounds. While the Digambaras were busy in performing the $p \bar{u} j \bar{a}$ (see Figure 12), Nitin Ajmera, president of the Jain Center of America who himself is a Digambara Jain lay person told me to visit fourth floor where a group of women were cooking (see Figure 13). These Jain lay women belonged to the Śvetāmbara sect and they were cooking lunch for the group of the Digambara Jains who were gathered at the temple for the $p \bar{u} j \bar{a}$. The Śvetāmbara lay women were cheerful, busily engaged in the cooking and chatting excitedly with one another. I introduced myself and joined them, offering a helping hand every now and then. I felt very comfortable. They seemed preoccupied with how best they could offer their service to the Digambara Jains worshippers and other sects that came to the temple. They traded accounts of previous events, especially, when they all worked together during shared religious festivals. For a while, I said nothing. I only listened to their conversations, which informed me more than any interview I had conducted. Their enthusiasm for their unity and sharing a common 
Jain identity was clear and expressed through the commitment they showed as they cooked for the other sect that was busy performing their rituals on the second floor. After a while, I started talking to them one after the other. I decided to prompt discussions on issues instead of asking direct questions. Thus instead of asking about their perceptions on the negotiations, I would ask, “why didn’t you order food from outside?” For the Jains in the USA, it is not impossible to place an order to a catering service for communal feast, a practice which represents a novelty and expressed the ethos of inventiveness. This question pulled out stimulating views and experiences about their sense of community and the negotiations. The women in the group informed me that they felt it was a part of working towards the negotiations when one sect helps the other. According to them, the sectarian negotiation is "unique" and it allows "working together, meeting everyone, and developing mutual relationships.” I interviewed Heena Jota, Sadhna Mehta, Pushpa Shah, Roopa Shah, Amita Shah and Shobhna Mehta from the group (see Figure 13). They celebrated the unity at the temple and within the community as the following summary of one response shows: "the sectarian negotiations make the environment of the temple lively, it looks good.” They described how worthy it was to work together at the same place by saying "a common temple provides us opportunities to meet everyone and understand them well.” A specific response drew my attention, "working in a group improves management and co-ordination skills.” This reveals how the idea that they would be more effective as a group if they came together, was an important force behind the negotiations. They seemed so impressed by what they had achieved that they said "India (Indian Jains) should also follow this model of sectarian negotiations.” 
One elderly lady, who belonged to a second generation diaspora family, and had migrated from South Africa to the USA was very appreciative of the fact that even the younger women were actively involved in the negotiations. For her working for the other sects was the mantra towards a success of the negotiation at community level. It was also the epitome of the demonstration of their awareness as one group. It was a usual working day in the USA, every woman in the group had made arrangements at their respective homes for their absence during those 6-8 hours they would be away from their routine domestic chores to cook food for the Digambara sect. As many other cultures, Indian culture do strongly believe in sharing of a common kitchen as a way of sharing a sense of unity. The diaspora Jains in the USA are no different in retaining the same concept. Purvi Jain, who belongs to the Digambara sect and a native Hindi speaker who lived in New York for last thirty-five years, expressed this idea in the following words "the kitchen is one.” She seemed oblivious of her diasporic context when she passionately talked about how the environment of a common Jain community is making her feel like being at home. My interactions with the group of women came to a conclusion with the freshly cooked meal. I ate and rushed to participate in the $p \bar{u} j \bar{a}$ which was still on. What these events and words show is that the negotiations among the Jains in the temples I studied in the USA go beyond the religious harmony thus created. They are played out at social and cultural levels. 


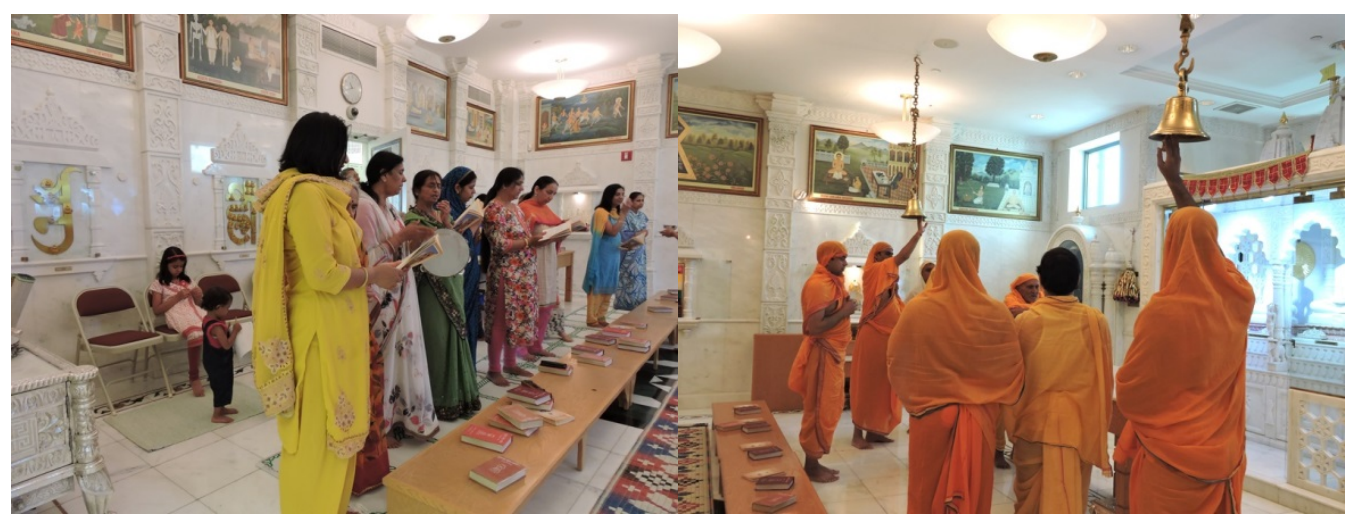

Figure 12. The Digambara Jain worshippers performing the $p \bar{u} j \bar{a}$ at the Jain Center of America

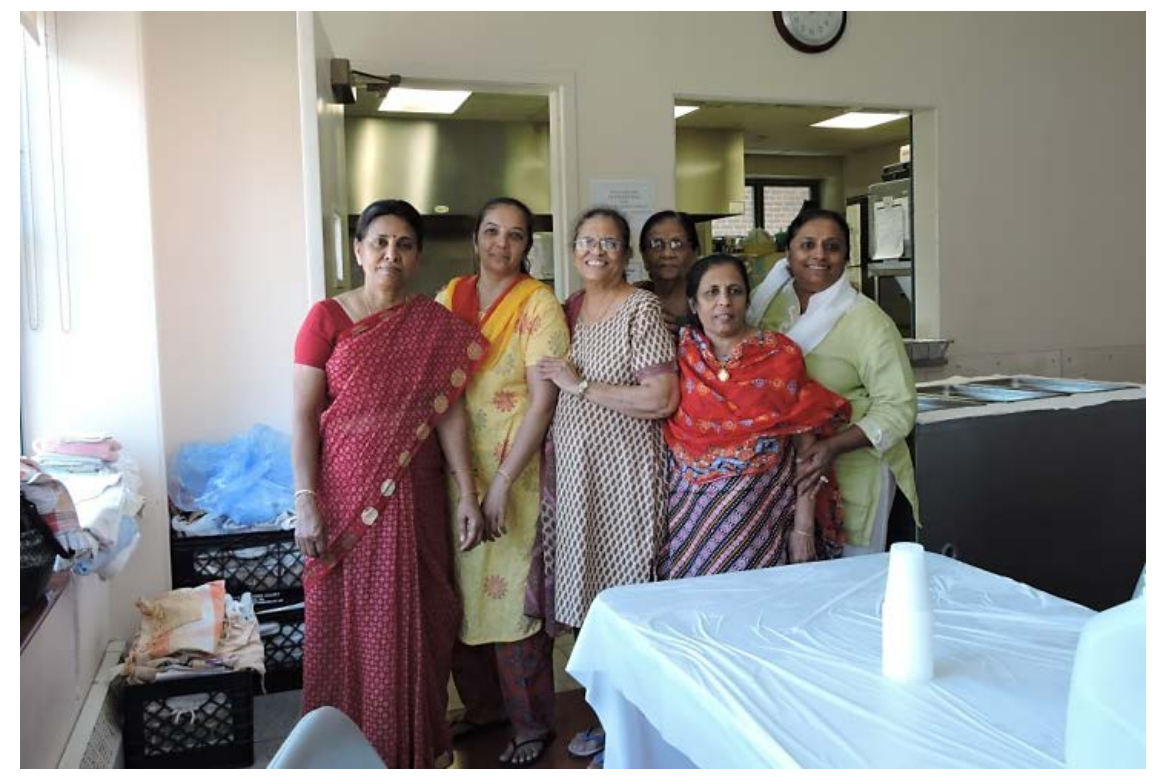

Figure 13. Lay women form the Śvetāmbara sect in front of the kitchen while cooking for the Digambara Jain worshippers at the Jain Center of America

\section{Management and Decision-Making}

I observed practices of seamless management and co-ordination at all the four Jain

centers I visited for my ethnographic study. I saw that decision-making and management serve as imperative elements for the Jain centers at social and religious levels. I take this to be critical to understanding the approaches the Jain centers adopt in management and decision making processes to maintain the sectarian negotiations. I had gathered views, 
perceptions and experiences of the community members about the sectarian negotiations at the temples. In order to understand how management and decision-making play their role in upholding a common, formal Jain community, I interviewed executive committee members of the Jain centers-temples. As I discussed earlier in chapter 3 there are unpleasant disputes between the groups of Indian Jain at levels of sects, castes and cultural, lingual and geographical areas over the issues of doctrinal, monastic lineage, pilgrimage places and temples. My intention in referring to them was not to criticize the Jains in India for their schisms but to present a picture of differences that occasion their disagreement. However, as the Jains in the USA promote the sectarian negotiations, the actions supporting the negotiations reflect in the management of the centers and decision making processes.

All the Jain centers (temples) are registered as organizations or corporations and have their bylaws. Typically the Jain temples are referred to as a 'center', as they include all sects of Jainism. The management body comprises the board of directors, executive members, and other sub-committees for events or special tasks. The members on the board of directors and executive committees are elected through a voting system. Ownership of properties of the centers (temples) are administered and managed in the name of the corporation to real estate, securities, and trust funds by the board of directors. The details of this management structure and system are easily accessible on the website of every center. However, since such details are not enough to present a broad picture of the model of management, it was necessary for me to take a deep look into the internal structure and approaches of the management and decision-making in order to study how they impact the sectarian negotiations. 
One Sunday in July 2016 at the Jain Center of South Florida, it was around 12:30 pm. Most worshippers including me were interacting with one other informally, chatting and laughing after participating in the worship rituals and before the lunch. I wanted to interview the executive committee members/board members in order to understand the system of management and decision-making. I approached an executive committee member, Mr. Lax Shah (see Figure 14), a Śvetāmbara Sthānakvāsī lay Jain. A very calm and dignified persona, Mr. Shah is very soft-spoken. I asked him a direct question, "How do you manage the Jain diversity at one place?” He replied “We are five sects together here and we make sure that each sect gets its representation.” He was pointing towards the diversity of Jain visual and ritual culture at the temple. What he mentioned was very well observable at the temple. I will discuss the sectarian diversity at the level of visual and ritual culture later in chapter 5 . He encouraged me to talk to other executives at the temple. I quickly ran to Jayant Shah, a senior Jain male, a Śvetāmbara Derāvāsī, expresident, member of board of directors, and the chairperson for the pratisth $\bar{a}$ (the consecration of an idol or image in a temple) ceremony in 2009. I asked him the same question. He showed me his hands and said "I promote five fingers (sects) concept; all are friendly here at one center (temple).” He added “To put all together, we support each other on a sectarian level and we also respect sectarian rituals. We even teach children the inter-sectarian rituals and philosophy, which eventually help them to cultivate the understanding of sectarian negotiations.” In the pursuit of further information, I talked with Bindesh Shah (see Figure 14), who is the member of board of director (Jain Center of South Florida and also JERF (Jain Education and Research Foundation) and who played a role as a project manager during the construction of the temple in 2005. He 
informed me about some interesting stories that shed light on how the negotiations played out in the management and decision-making processes. He mentioned that "we all participate in every activities of the temple together.” Then I asked him to elaborate on the decision-making for the celebration of the Paryușana festival. He started into an explanation, "In India, the svāmi-vātsalya bhojan (community meal) is held immediately after the Paryușaṇa ends. But we organize after the Daśalakșanaparvan (festival of ten righteous virtues) ends.” As I mentioned in chapter 3 the duration of the days for the Paryuṣaṇa festival are different for the Śvetāmbaras and the Digambaras. For the Digambaras, the duration is ten days, a day longer than the duration for the Śvetāmbara version. This demonstrate that the center which has more members from the Śvetāmbara sect incorporate the Digambara sect’s structure of Paryușana and enjoy the community meal together. Bindesh Shah then smiled and recalled an incident during which they had ordered the images of the Jina for the temple only to note that the images were small in size. They wanted a taller version. Instead of sending the images back to India, they decided to auction ${ }^{14}$ the images. He described how many Sthānakvāsiss ${ }^{15}$ auctioned for the images and installed them in their homes. Bindesh Shah attributed this sense of unity to a good management structure that allows the community members to accept, respect and participate in inter-sectarian activities at a religious level. Bindesh Shah is also the president of JERF (Jain Education and Research Foundation), which is a distinct foundation in the USA that helps foster Jain philosophy and religion in the world of academics in the Americas. He was happy to share how the JEFR does not support any

\footnotetext{
${ }^{14}$ The auction or bidding is a public activity performed by the Jain lay people within a community to bid for the right to perform certain ritual actions.

${ }^{15}$ Sthānakvāsī is the non-image worshiper sect of Jainism.
} 
particular sectarian doctrine, philosophy or religious leader. I found out from my interaction with him that the decision-making processes within JERF follow the sectarian negotiation format, which entails incorporating diverse viewpoints of Jainism. See Figure 14 which includes myself with Lax Shah and Bindesh Shah after interviewing them at the Jain temple, South Florida.

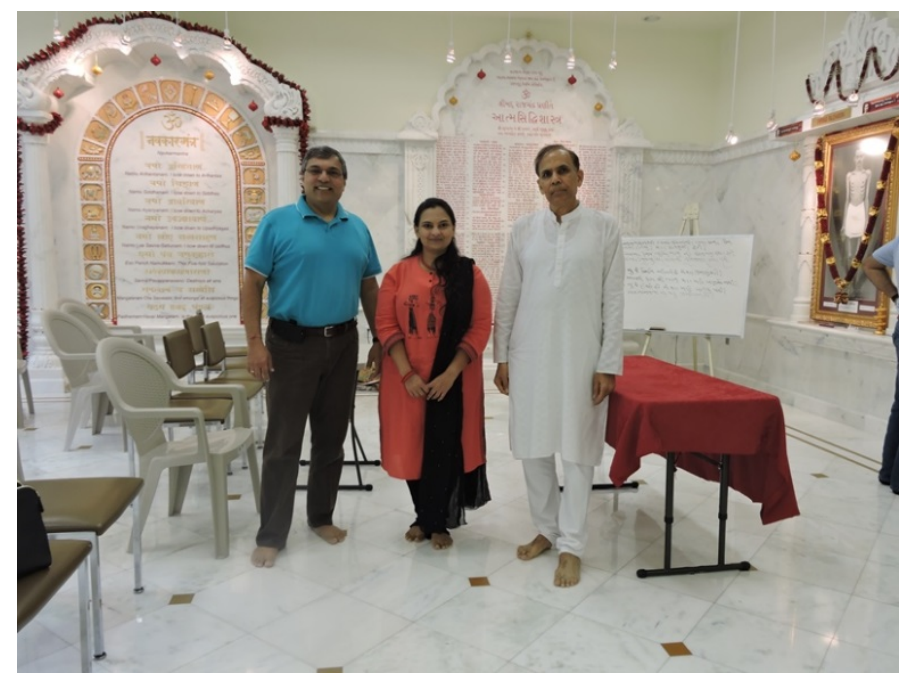

Figure 14. The management committee members, Jain Center of South Florida

I will now talk about the Jain Center of Greater Phoenix; the center is a house of 100 to150 Jain families. I visited this center on the day it re-opened after a summer break for the usual temple activities such as worshipping, social gathering and pāthaśála etc. The day at the center began with a community gathering. Of course I had many questions regarding the management structure, but Chirag Shah, the young and energetic president of the center told me to observe the community gathering meeting to see how negotiations are playing out in the management. I sat down among the community members. The meeting began with many announcements regarding the forthcoming temple activities, social-outreach activities and about the pāthaśălā. The discussion that 
took place during the community gathering offered enough to demonstrate how the center manages the sectarian negotiations at social and religious levels. One after the other members stood up and presented the plans of the activities, which would be carried out during the year. There was no sectarian specific discussion. I was still curious to know more about the decision-making processes and I discussed this at length with Chirag Shah while he drove me to the International Hosteling in Phoenix, the place I lived during my fieldwork there. During my interaction with him, I found out that they were not focused on the sectarian divisions. He pointed out that every member of the community supported the unity of the center and that this situation makes the negotiation stronger. The decisions are taken collectively and by voting. According to him "There is no scope for any differences at this center.” I interviewed a senior community member, Kirit Gosaliya, from the Digambara sect and a follower of Kānjī Svāmī Panth, who also happened to know one of the families from the Sthānakvāsī upāśraya I belong to in my hometown Bhavnagar in Gujarat-India. My conversation with him evoked my positionality as a Sthānakvāsī. I asked him "how are the decisions made when there are Jains with different religious and social background at a one common place?” He smiled and asked me back “Did you see any point of conflict during your visit!” He explained that they approach the decision-making processes from a philosophical point of view. For them at the Jain Center of Greater Phoenix, every decision is made by adopting the view that Jainism is one at its core, and there is no division. I infer that this strategy of managing the sectarian negotiations is driven by the worldview that there is no division in Jainism itself at core, therefore, there is no room for the differences of opinion in the decision-making process. 
After describing the two relatively smaller Jain communities, I now present the account of the other two temples, which are bigger than the two I discussed. I observed during my fieldwork at the Jain Center of America in New York that rigidity gives way to flexibility when a sense of unity takes over. This was not evident only at the religious and social levels but also at the level of management. More than 1200 Jain families are affiliated with the Jain Center of America in New York. The temple is unique in its visual representation of the sectarian and social unity, but, I would talk more about this aspect later in the chapter 5. I find it important to mention here that Nitin Ajmera, who belongs to a Digambara sect is the president of the Center in which there are only about 100 families of the Digambara sect among all other sects. This was Nitin Ajmera's first reaction to my question regarding the management of a community characterized by sectarian diversity. He said “Acceptance of unity in diversity is demonstrated at the management level at this center. This is evidently appearing in the fact that I belong to the Digambara sect, which is smaller than the other sects represented in this community at the New York. Still I am the president.” His method of management and decisionmaking was supported by the notion of a common and shared faith. He specifically mentioned that "Our diversity is a part of our faith.” A businessman by profession, Nitin Ajmera asserted that the community practiced tolerance and peace for all, and this reflects in the management style. The Jain Center of America is the temple with large diversity at caste, lingual, cultural, and geographical affiliations. Jains who are members of this center come from various parts of India and also from some part of Africa as second diaspora. This center is even more diverse at the domains of caste and language. Nitin Ajmera is a native Hindi speaker, while majority of the community members are 
affiliated with the Gujarati language. Nitin Ajmera also points out that the management is successful in "breaking the walls by creating a common Jain community and temple.” On a personal note, he added that "Negotiations help me to plan better, I have learnt lessons of comprehensive management for my personal life by organizing the diversity of this Jain community at this center.”

Now I focus my attention on the fourth site, the Jain Society of Metropolitan Chicago. I visited the Jain Society of Metropolitan Chicago on one pleasant morning in June 2017. It was 6:45 am when I called a cab; the cab driver was familiar with the Jain temple and even more excited about the fact that I was conducting an academic research in the temple. He happily shared some of his experiences about Indian diaspora community in Chicago. It was 8:30 am when the cab entered into the lush green compound of the Jain temple. I entered the temple, took my time to gaze at its visual culture $^{16}$. Worshippers gradually started to string in. The center was alive with the presence of more than 450 members by $10 \mathrm{am}$. My visit to a Jain temple in India would have a single objective - darśana of the image, seek blessings and return home. I would never think of interacting with other Jains from different sects at a temple. This however, was not the case at the Jain centers that I visited during my fieldwork. Community members meet and interact across sects. Dr. Mukesh Shah, the chairperson of the center suggested that before I interviewed him and other members from the management body (see Figure 15 below), I should participate in every activity of the center and interview as many people as I could. I followed his directives. I was invited to a meeting room towards the end of my fieldwork at the center. There I met all the members who were part

\footnotetext{
${ }^{16}$ Visual culture means the aspect of religious culture expressed in visual images such as temple architect, images of sacred, paintings, decorations, etc.
} 
of the management of the center. I interviewed Dr. Mukesh Doshi, a very lively and pleasant man. "Since when you are living in the USA?” was my first question for him. Replying funnily, he said “for much earlier than you were born, means, since 1976." The interaction between me and the management body began with this light remark. There were more than three members present at this group interview. According to Dr. Mukesh Doshi, the management towards the sectarian negotiations meant establishing accordance at doctrinal and philosophical levels. To elaborate this point he said “Jains from India criticize us for having all the sects at one temple, but, we ignore the criticism and maintain unity by taking help of the Jain philosophy itself, which teaches us to be united and not to find differences." He informed me that to maintain the unity between the sects at the religious and social levels, the management of the center makes a point of cautioning any religious leader who comes to the center to give a lecture, against mentioning differences in Jainism. In his words "We do not allow any spiritual- religious speakers to be sect-specific in their lectures at the center. We do not want their lectures to disorient us from being united.” Dr. Doshi’s views were firm but it did not reflect disrespect towards any spiritual- religious speakers. I came away with the sense that the management of this center considers doctrinal disputes as the chief impediment to the notion of the negotiations. For this reason the management guards against contestations of doctrinal questions among community members of the Chicago temple. Other members present there also agreed to what Dr. Doshi mentioned. I found that their management model was centered upon upholding a common accord between the sectarian doctrines within Jainism. Kushal Singavi, who is an active person of the management at the center emphasized that "We take decisions based on the learning from 
various viewpoints, we never refer the past, and going back to the history of schism within Jainism can remind us of differences. Therefore, we avoid such things while we make any decisions.” A young lay Jain male, member of the management body from one of the centers I studied said openly “We don’t have Mahārāj Sāhebs (male ascetics) or Sādhavìjis (female ascetics) here; they make you follow a particular ideology.” His concern showed that the management wants to protect the unity among the Jains by putting any possible efforts.

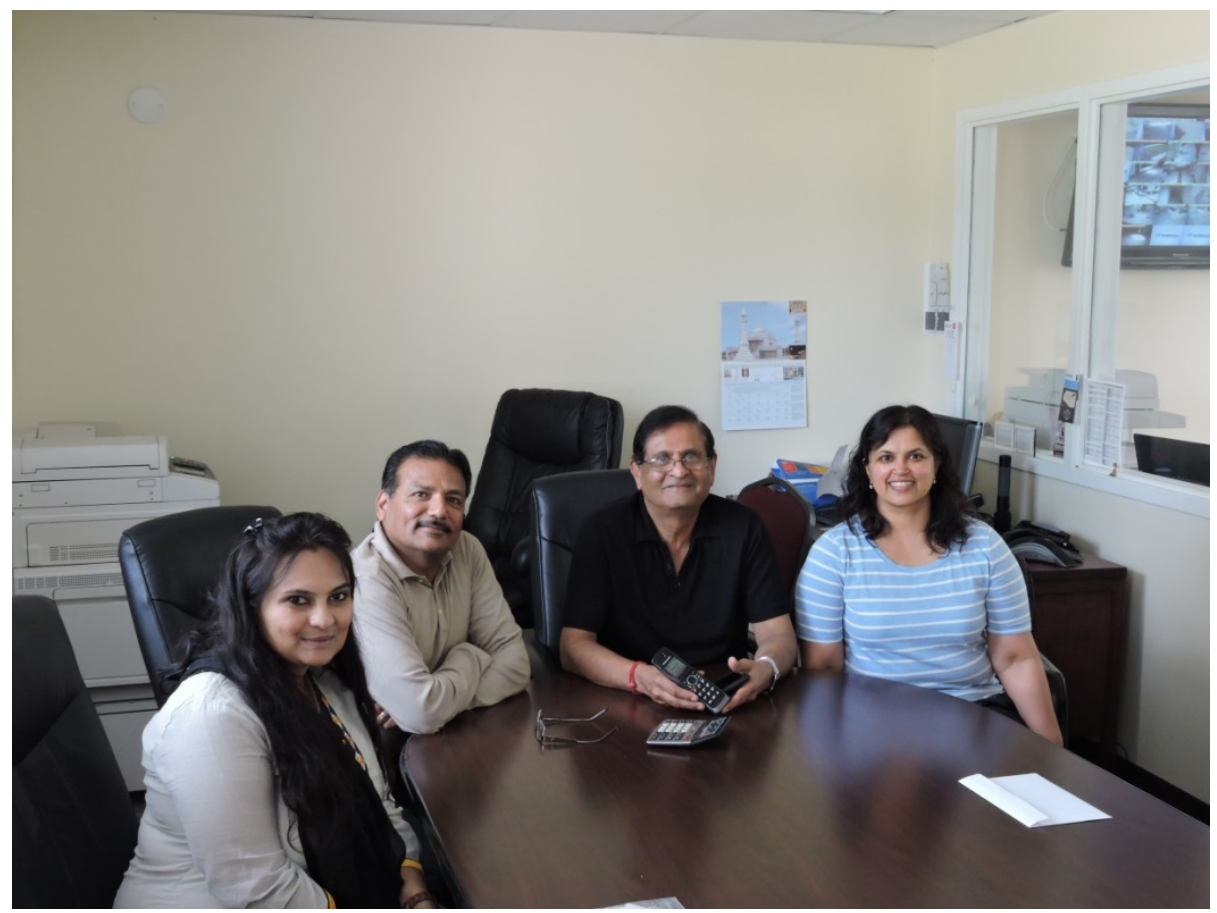

Figure 15. An interview session with some of the management committee members, Jain Center of Metropolitan Chicago

I argue that all the four centers-temples have their own unique patterns and approaches to management and decision-making to push forward the negotiations at sectarian level. I observed that management committees didn't refer to the influence of 
castes, languages, or geographical affiliations as an obstacle in securing the unity of the community. I concluded essentially that the management approaches adopted by the executive members at all the Jain centers were socially focused, oriented towards sectarian negotiations and were inspired by the Jaina philosophy of anekāntavāda. In chapter 6 I will discuss this philosophy into greater details, emphasizing, how it shapes the values that inform the negotiations and invention of a new form of Jainism in the USA. I assess form the interviews and my observation that the sectarian negotiations are strengthened by the management and decision making at the horizontal levels. Moreover, I perceived that the hierarchy or supremacy over management is underplayed or absent.

\section{Conclusion}

The sectarian negotiations among the diaspora Jains in the USA in the form of creating a common, formal Jain community resemble the principle of causation. I conclude that the sectarian negotiations are the willing creations that help the Jains to meet their religious and social needs. However, the negotiations which began to work for the religious unity and social cohesion enlarge the scope and incite the community's formation of a new identity - a common 'Jain' identity. The negotiations do not limit to the notion of a group consciousness among the diaspora Jains. The formation of a common, formal Jain community among the community members also involve essential observable element such as formation of a distinct common 'Jain' identity among the host community and other diaspora groups in the USA. 


\section{CHAPTER 5}

\section{Place-Making, Ritual-Visual Culture: The Invented Tradition}

\section{Introduction}

By using the processes of the sectarian negotiations, the diaspora Jains are producing and reproducing themselves anew through processes of transformation. I argue that the diaspora Jains are recognizing a necessity of heterogeneity and diversity, not only at the sociocultural level, which is forming a common, formal Jain community, but also at the religious level in the form of place-making. I discuss in this chapter how, as the negotiations among the Jains advanced at sectarian levels, they reflect in the form of the invention of the new visual and ritual culture. I demonstrate in this chapter that the invention of ritual-visual culture begins with place-making, which takes the form of the construction of Jain temples.

I interpret the invented ritual-visual culture as a new form of Jainism because it is different from the Jain ritual-visual culture present in India. I use the concept of placemaking to identify the Jain diaspora community's effort to construct a home in a land of settlement. Following the study of place-making in the form of Jain temples, the chapter demonstrates how the Jains in the USA have invented a new set of ritual-visual culture within the premise of the temples that I studied. I do not intent to describe details of Jain worships rituals or images in this chapter. Rather I will discuss the ways Jains in the diasporic context create a new version of ritual and visual traditions. The focal point of this chapter is to depict the invention of tradition, a new form of Jainism by studying the ritual-visual culture constructed by the diaspora Jains in the USA. 


\section{Place-Making and the Jain Centers (temples): the Footing towards the Invented Tradition}

"We value a Jain temple more because it is rare to have a religious place on a foreign land (USA). I am thankful to those who have built this temple. We feel like home.” These are the words of a young Jain worshipper Pranav Shah who has lived in the USA since 1998. The Jains with whom I interacted during my fieldwork at the four different temples share similar views. Moreover, what is more intriguing about the four temples I visited during my fieldwork is the sense of comfort and confidence the Jain diaspora community members expressed about the status of their "Jain Temple." To analyze the process of the place-making by the Jains in the USA, I interpret their narratives by employing the relationship between religion and place-making. In doing so, I evaluate building of a temple by the Jain community as the process of place-making on a map of the USA.

I use Levitt's assertion to situate the discussion within a context of religion and place-making for the diaspora Jains in the USA. Levitt points out "religion plays a critical role in identity construction, meaning making, and value formation. Migrants also use religion to create alternative allegiances and places of belonging” (2003: 851). Moreover, Vasquez's (2005) discussion also points out how religion helps immigrants “imagine their homelands in diaspora, inscribe their memories and worldviews into the physical landscape, and built environment ’ (238). In this regard, I argue that like any other diasporas, the Jains in the USA are also the deterritorialised population who are involved in the need to create a place of belonging through religious mappings and to delineate an alternative “cartography of belonging” (Levitt 2003:19). 
As I discussed in chapter 3, as a religious minority group of immigrants in the USA, the Jains formed an ethnic group identity, that is, a common Jain identity in the USA. Similarly, I evaluate building of the Jain temples as an endeavor by the Jains to locate themselves in the new landscape in response to their dislocations generated by modern and pluralistic setting, globalization and multiculturalism (Warner 1993, Repstad 1996 and Vasquez \& Marquardt 2003). Following this perspective, I argue that Jainism, notion of displacement, and need to locate in a new setting have played key roles in the place-making processes of the Jains in the USA. However, keeping this in the context, I evaluate how building of the Jain temples offers two significant aspects of the Jains in the USA.

The first aspect I argue is that the sectarian negotiations are key influential factors behind the building of the Jain temples in the USA. Relatively small number of Jains in the USA shared common temples with Hindus and utilized common worship facilitates known as 'Hindu-Jain Temples' during 1980s (Long 2009: 14). The rise in the construction of separate Jain temples in the USA is relatively a new phenomenon. The four Jain temples I visited in my fieldwork were constructed within the past twelve years. However, all the four communities I studied were formed as an organization in the late 1960s. According to the Jains I interacted with, the building of a temple on a foreign land could become possible only when all the sects come together. This means, uniting in large numbers helped Jains to meet the financial and administrative demands required to build a temple. Thus, I evaluate the sectarian negotiations as the essential marker to describe the inception of building a Jain temple. The second aspect that draws out from the study and assessment of the four temples sites is the concept of invention of tradition. 
For the diaspora Jains in the USA, the temple is a place that houses various Jain sects and sub-sects. On a first sight, I observed that a Jain temple serves as social gathering place for the community members to interact. Nevertheless, most importantly, the Jain temples demonstrate salient features of syncretism, re-arrangements and creation of ritual-visual culture. I found out in my study that the Jains have created unique versions and patterns of rituals and arrangements of visuals to accommodate the needs of all the sects. In this regard, I evaluate the creation and arrangements of the rituals in the temples and the temple architect reflect the new form of Jainism.

The place-making for the Jains is not just limited to the building of Jain temples. It extends its scope to the construction of new understandings of Jainism in comparison with their counterparts in India. The sectarian unity also reflects in the matters of worshipping and celebrating religious festivals. I observed that this new form of ritualvisual culture has affected the ways in which the Jains from various sects in the USA perceive and receive their sense of Jain rituals and visuals. Organized around the idea of maintaining the sectarian negotiations among the Jains, various arrangements at ritual and visual levels have influenced the worshippers' interactions with the sects other than their own. Moreover, my study reveals that the multi-sectarian images in the temples and methods of worshipping have enhanced the sense of unity and exchanges among the members of different sects. The Jains' use of place-making by constructing common Jain temples is seen as social, communal, and religious deliberations which eventually resulting into ‘invention’ of tradition. This means invention of diasporic Jain ritual-and visual culture. 


\section{The Jain Temples in the USA and the Visual Culture: A Shift from Traditional to Invention of Tradition}

I mentioned in chapter 3 that the Jains from different sects in India do not find accord in the ownership of the pilgrimage places. Each sect has its own temple or place of worship designed and decorated according to its respective sectarian structures. Moreover, there are no assigned similarities in the appearance of the sacred images, especially for those of the Jina’s images. This also plays out in various approaches and methods of worships and celebration of festivals. It is important to mark here that the differences are founded on the fundamental doctrinal differences among the sects. I will use select features of visual culture present at the four temples I visited to demonstrate the invention of tradition.

The ‘invention' of tradition is expected to occur more frequently when 'old' traditions no longer prove sufficiently adaptable and flexible for a new environment (Hobsbawm 1981). For the Jains in the USA, the temples are an extension of their social construction in the form of a negotiated product (Beckford 2003). I argue that the four Jain temples I studied are constructed with old sacred materials. Nevertheless, the communities have invented a tradition at the visual culture level as pragmatic adaptations to novel situations produced by the sectarian negotiations.

In the case of India, for the Murtīpūjaks (image worshippers), a Jain temple is a place where sacred images of Tīrthankaras are worshiped. The images of the Tīrthankaras are central to the temple, while other images such as ancillary deities and ascetics of the past are also present in a typical Jain temple. Some images in the temple are fixed while, some are movable. A Jain temple is divided into two parts of sacred spaces, which includes a main hall and an inner shrine in which the images of Tīrthankaras are installed. 
A temple's main image is called $m \bar{u} l n \bar{a} y a k^{17}$ (root lord) which is at the center of the altar platform. Other Tīrthankaras images are installed on either side of the main image (Babb 1996, Banks 1992 and Dundas 2002). Moreover, for the Sthānakvāsī, the iconoclastic tradition of Jainism who rejects image-worshiping, upāśray (empty building) is the sacred religious place. The upāśrays do not include any sacred images (Humphrey \& Laidlaw 1994 and Flügel 2006). In addition to these types of different religious dwellings, the iconographies of the Tìrthankaras are also dissimilar in both major sects. Keeping this visual information about typical Jain temples in my mind, I visited all four temples site. Though all four temples share similarities in certain their visual culture, each temple has a unique pattern of inventing a new form of Jain visual culture. Therefore, I will discuss and analyze all four temples separately. I will begin with the Jain temple of South Florida (the Jain Center of South Florida). In my very first visit to the Jain temple of South Florida I observed a temple which was different from the visuals I had of any typical Indian Jain temples. The placemaking of this temple is different in layout. The temple is located in a commercial complex in Weston. Viewed from outside the temple does not resemble a typical Jain temple since the structure of the building is a commercial one. The temple is divided into two major zones. The larger area is the main hall. This has all the visual images. This part is used for worship, religious gathering and lectures or meditation. The other zone is used as a dining and sitting area. There are two small rooms attached to the dinning and sitting area. The community uses the rooms for pāthaśála activities and as the temple’s office. The temple is relatively smaller in comparison with the other three temples I visited. In

\footnotetext{
${ }^{17}$ The principle image in a temple.
} 
spite of the smaller size, the temple incorporates visual representations of both the major sects and sub-sects. The arrangements for displaying the sacred images and objects are creatively managed and include the blend of multi-sectarian presence.

As I entered the temple building, the first sight that drew my attention was the Śvetāmbara and the Digambara images of Tīrthankaras as mūl nāyaks in the main garbha griha ${ }^{18}$ of the temple. Figure 16 shows the images of Mahāvīra in the center with Sīmanḍhar Swāmī and Ādinātha on the sides. The iconography of the images of Mahāvīra and Sīmanḍhar Swāmī are part of the Śvetāmbara tradition. In addition, the image of Ādinātha is according to the Digambara, an iconographic version of a Jina's image. Moreover, the images of twenty-four Tîrthankaras sitting on both sides of the main platform also demonstrate a blend of the Śvetāmbara and the Digambara traditions. The visual representations of the Tîrthankaras at the Jain temple of South Florida demonstrate the confluences of both the major sects in the main zone of the temple. This innovative arrangement is highly appreciated and well-received by the Jain community members affiliated with this temple. According to them, this invented design fulfills their needs of being closer to the sacred on a foreign land. The temple's use of space to integrate the visuals of sub-sects shows a laudable attitude towards respecting the concept of sectarian negotiations. All the walls of the main hall of the temple are covered with representations of the sectarian beliefs. There are visuals of Bhaktāmara Ślokas and N̦amōkāra Mantra ${ }^{19}$ (Navakāra Mantra) on the wall of the temple. Ācārya Manatunga, the author of Bhaktāmara Ślokas was a Digambara scholar and an ascetic. Each word of

\footnotetext{
${ }^{18}$ The inner sanctuary/platform of a temple.

${ }^{19}$ N̦amōkāra Mantra (Navakāra Mantra) is Jain prayer, recited at any time and also at the beginning of the any Jain rituals or worship.
} 
Bhaktāmara Ślokas reveals his enlightening devotion and infinite faith in the first ford founder Lord Ādinātha. This incorporation depicts the representation of the Digambara tradition. There is a display of a large full-size picture of Śrimad Rājcandra and an inscription of Ātmasiddhi ${ }^{20}$; and a two-dimensional wall pictures of and Śatruñjaya Tîrtha (see Figure 17). It is important to understand that the Śatruñjaya Tîrtha is the most important pilgrim site of the Śvetāmbara tradition on the temple walls. Though, the pictures and inscriptions are attached to the walls, they give a visual sight of an altar in the temple. The sectarian amalgamation was neatly visible as I stood in the middle of the main hall and observed the temple with a 360 degree view (see figure 16 to 19). Since I presently live in Miami, it was possible for me to attend special religious events organized by the Jain community of South Florida, which helped me to observe that the community continues to demonstrate a syncretism of visual culture (see Figure 20) during occasions such as like Mahāvīra Jayantī (Mahāvīra's birthday) and Paryușaṇa.

\footnotetext{
${ }^{20}$ Ātmasiddhi is a spiritual treatise composed in Gujarati language by Śrimad Rājcandra (1867-1901 C.E.).
} Ātmasiddhi is translated as self-attainment or self-realization. 


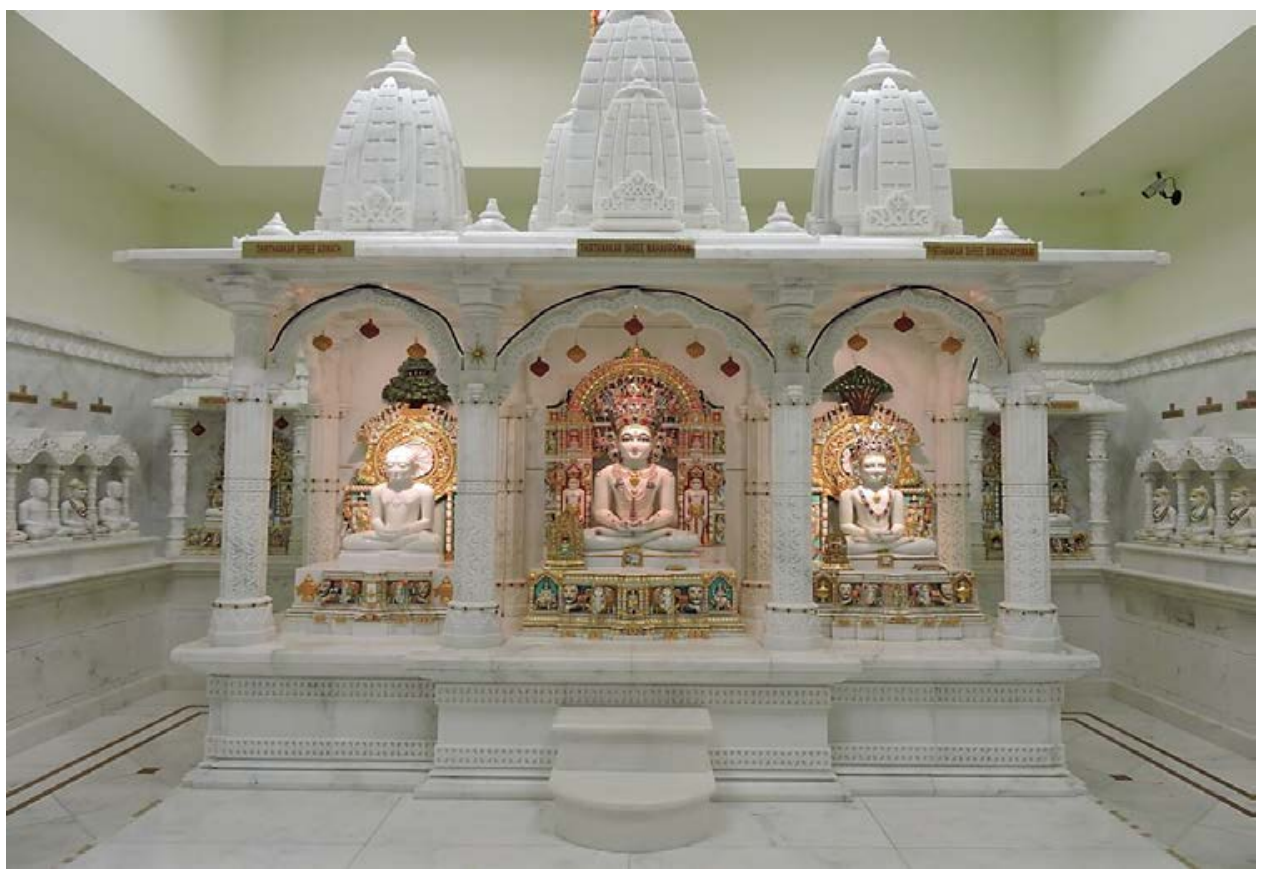

Figure 16. The Śvetāmbara and the Digambara images of Tīrthankaras as mūl nāyaks in the main garbha griha of the temple, Jain Center of South Florida

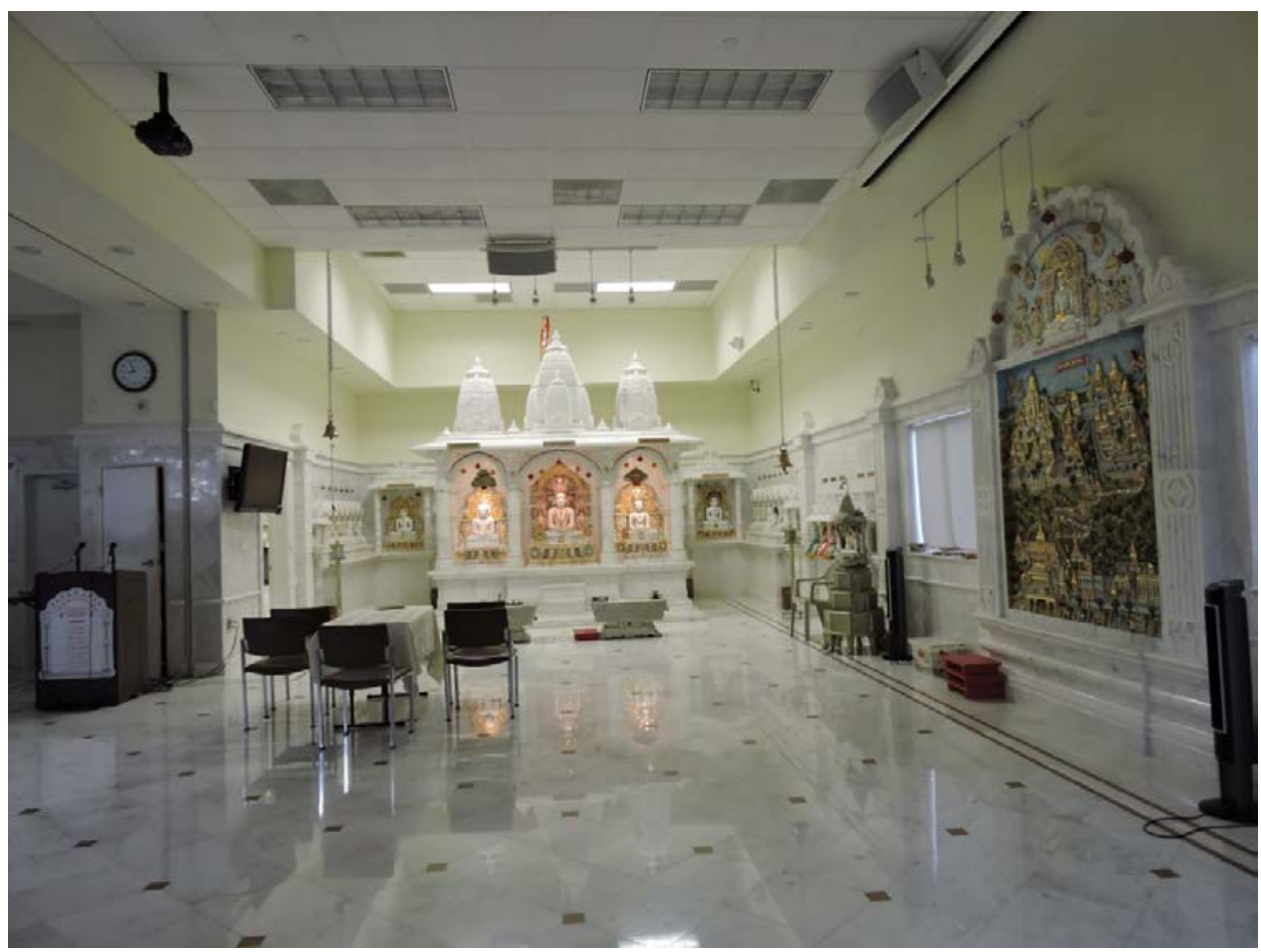

Figure 17. Śatruñjaya Tīrtha (right in the picture) at one of the walls at the temple, Jain Center of South Florida 


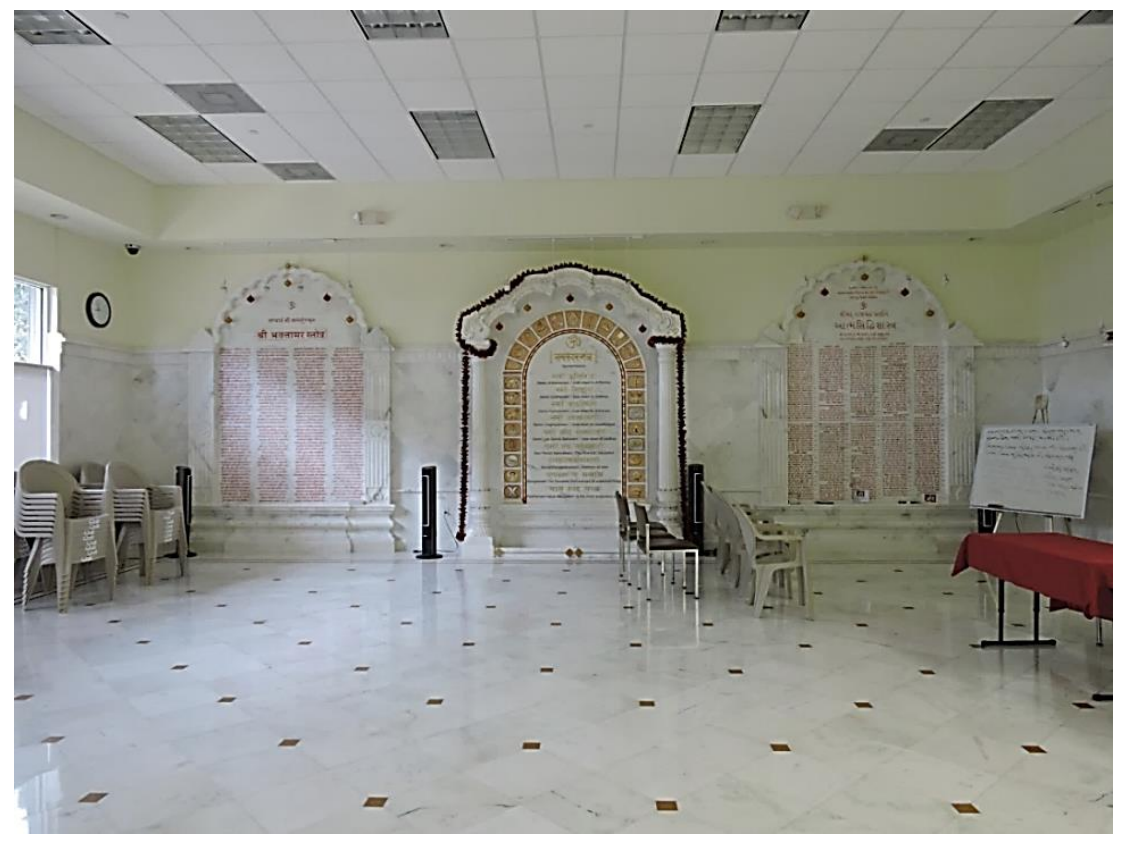

Figure 18. Bhaktāmara Ślokas, Ṇamōkāra Mantra and Ātmasiddhi at the temple, Jain Center of South Florida

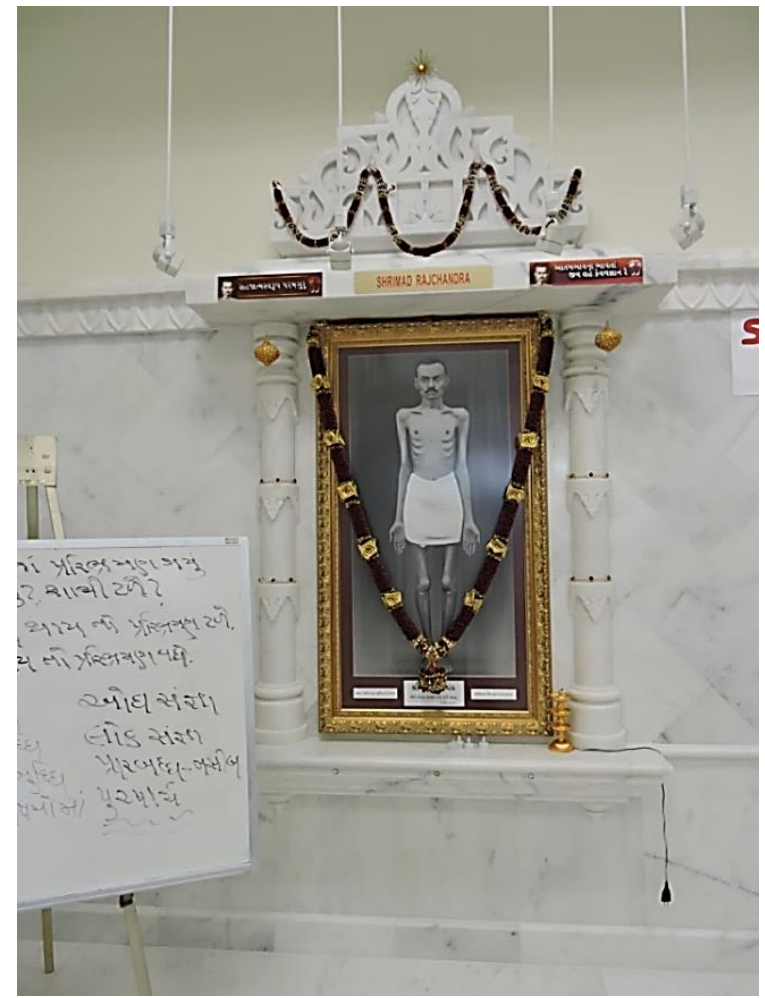

Figure 19. A full-size picture of Śrimad Rājcandra at the temple, Jain Center of South Florida 


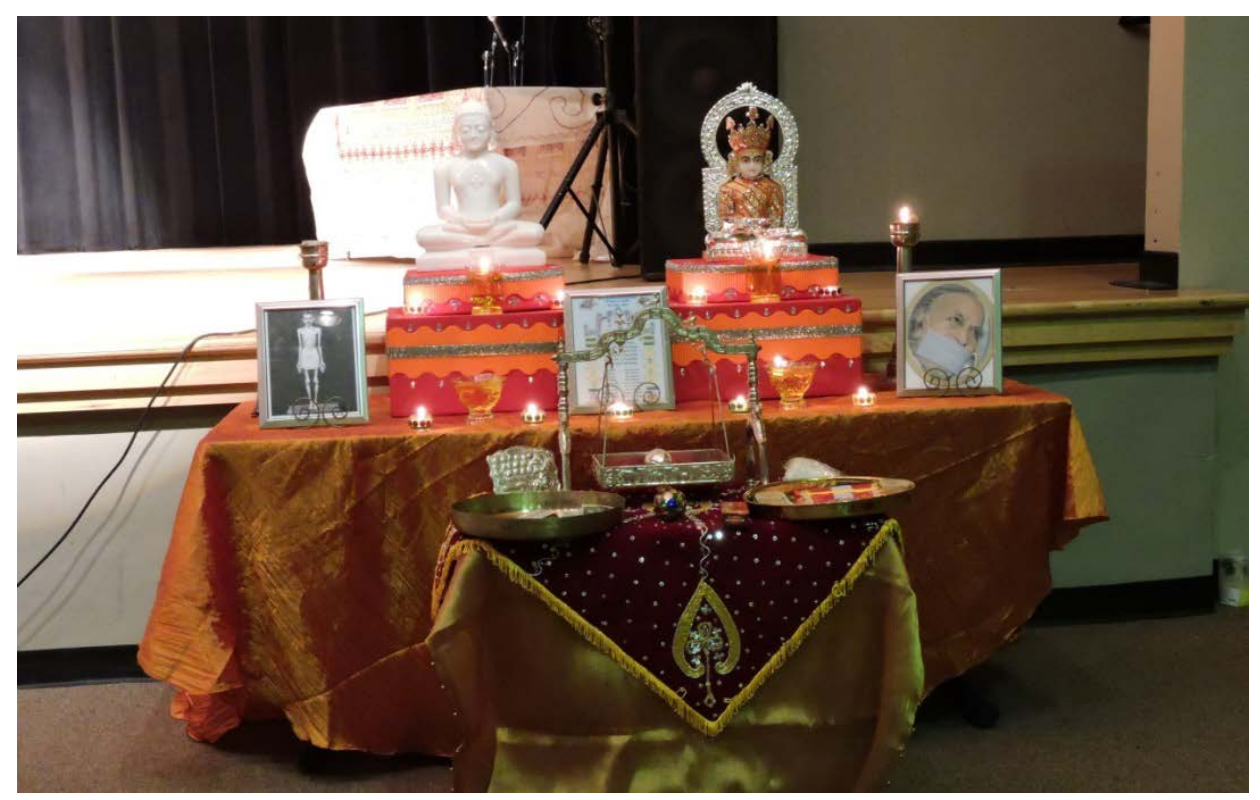

Figure 20. Images of all the five major Jaina sects at a common platform on Mahāvīra Jayantī (Mahāvīra's birthday), Jain Center of South Florida

The Jain Center of Greater Phoenix is a large temple, undivided by any zones, the temple has a main large hall. There is a main platform for the images at one end side of the temple hall which includes two images of the Tìrthankaras; one according to the Śvetāmbara version of iconography and the other according to the Digambara tradition. In addition to this, the main platform of this temple has three smaller shrines; two with the sitting icons of the Tīrthankaras and the middle shrine hold the picture frame of the Ṇamōkāra Mantra (see Figure 21). It was easy to assume that the middle shrine would have a picture of the Namōkāra Mantra. Nevertheless, there was something interesting about it than to assume, the president of the center (temple) told me that the community wanted to lead the sectarian negotiations in a form of a unique hybrid version of the image of the Jina. They had a design for the Tīrthankara image, which would have iconographic of both the Śvetāmbara, and the Digambara features. They wanted to order 
this kind of sculpture but it was highly criticized in the homeland and eventually they had to cancel the plan. However, the president was confident about executing the plan one day in the future to set a finest example of the sectarian negotiations.

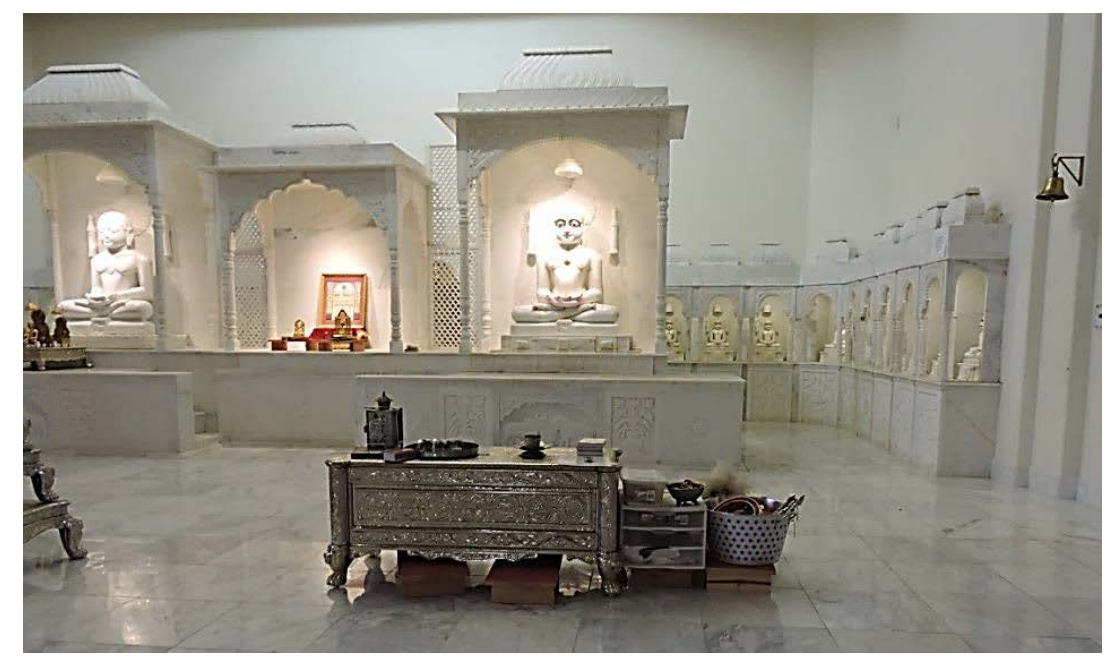

Figure 21. The Śvetāmbara, the Digambara images of Tīrthankaras and Namō̄āa Mantra as $m \bar{u} l$ nāyaks in the garbha griha, Jain Center of Greater Phoenix

The temple has a rich external architectural structure but delicately simple in its interior arrangement. However, at the level of visual culture, the temple represents the community's sub-sectarian diversity as well. For example, it has two-dimensional wall pictures of Gīrnār Tirth and Śatruñjaya Tīrtha. It is important to understand that the Śatruñjaya Tīrtha is the most important pilgrim site of the Śvetāmbara while, the Gīrnār Tirth is popular for both the main sects (Cort 2001 and Dundas 2002). The Jain community affiliated with the Phoenix temple has a few followers of the sub-sects such as Śrimad Rājcandra Panth or Kānjī Svāmī Panth. However, the community pays equal tribute to these sub-sectarian presences. The temple has dedicated a large room to meditation activities, philosophical discussion and reading. This space is creatively aligned with the visual presentation of the pictures of the Śrimad Rājcandra, Kānjī Svāmī 
and other reverend scholars-ascetics (see Figure 24). There is a poster in Hindi language that offers details of the twenty-four Tīrthankaras' family-birth and other biographical details. Like other Jain communities I studied, the community at Phoenix has members from various language affiliations such as Gujarati, Hindi, Marwadi, and other regional dialects spoken in India. The poster which offers the details on the twenty-four Tīrthankaras is in Hindi, which speaks largely to the effort of the community to accommodate every member's need, specifically inclusion of language diversity.

On one of the walls of the temple, the innovative use of aniconic visuals attests to the invention of a new form of Jainism. According to the Jains at the temple, the Ahimsā Stambh (a peace column) at the center of the temple compound is the philosophical and spiritual symbol of the sectarian unity among them (see Figure 22). Moreover, the temple has a false ceiling that projects the Jain symbol/emblem ${ }^{21}$ which presents the confluence of significant Jaina principles, doctrines; cosmology and philosophy (see Figure 23). The symbol also illustrates the Jaina aphorism, parasparopagraho jivanam which translates as 'souls render service to one another.'

\footnotetext{
${ }^{21}$ In 1975, this symbol was adopted by all sects of Jainism while commemorating the 2500th anniversary of the nirvana of Mahāvīra (Wiley 2006: 128).
} 


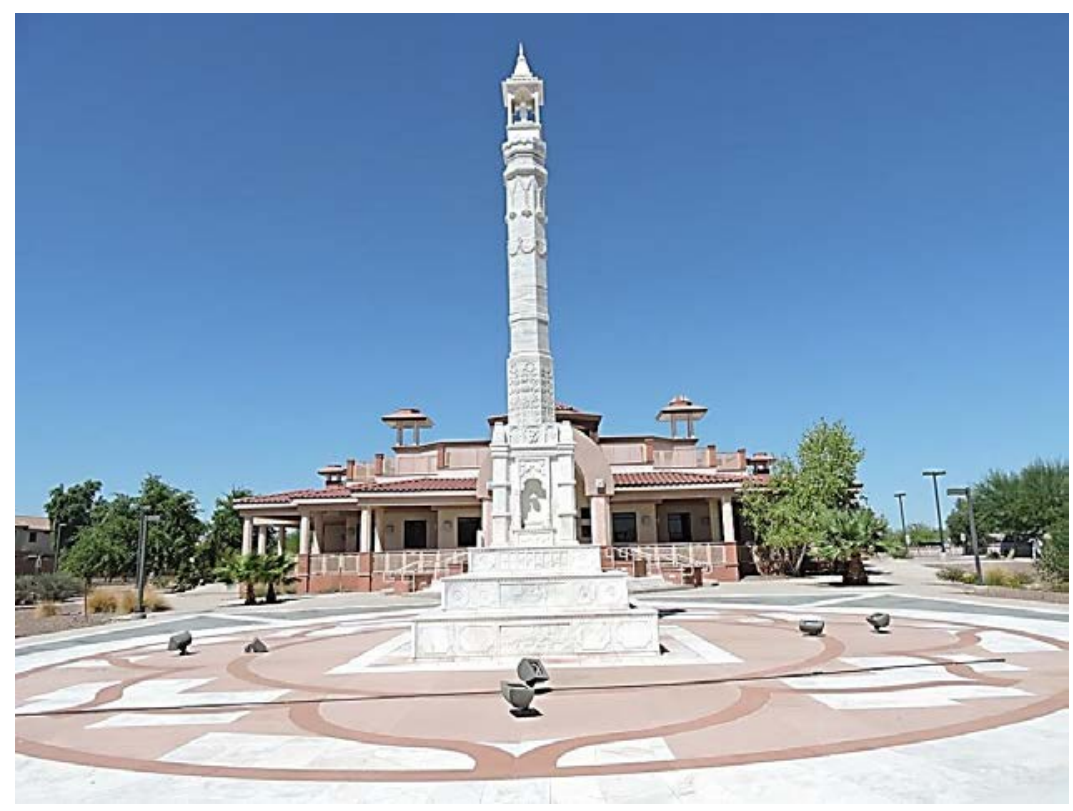

Figure 22. The Ahimsā Stambh (a peace-column) Jain Center of Greater Phoenix

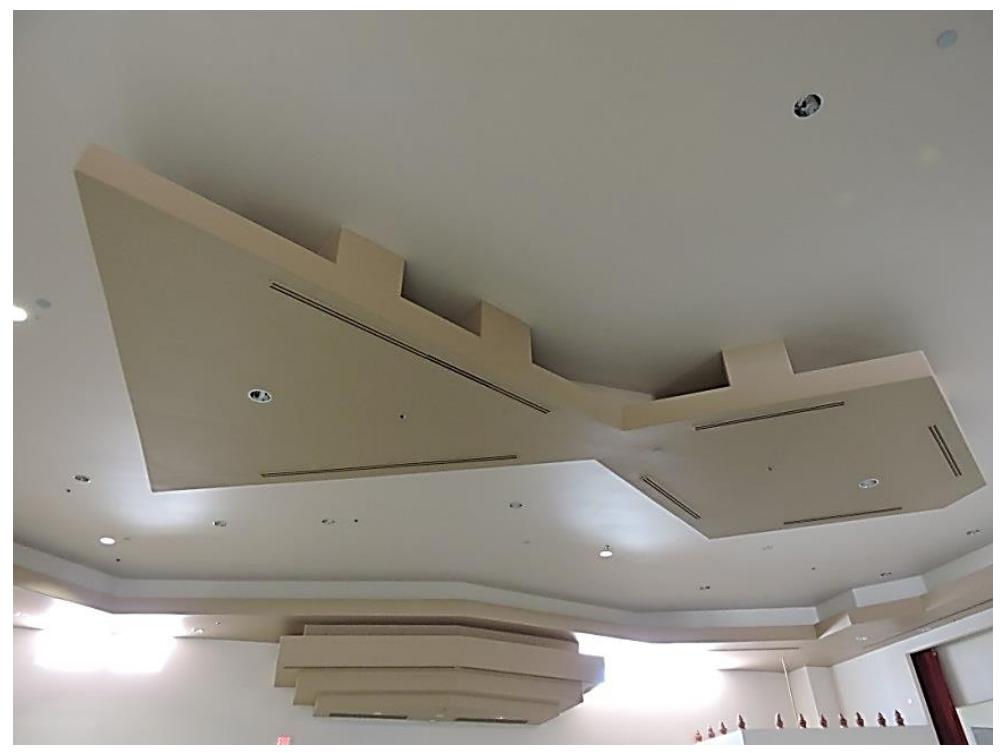

Figure 23. The Jaina symbol - aphorism, parasparopagraho jivanam at Jain Center of Greater Phoenix 


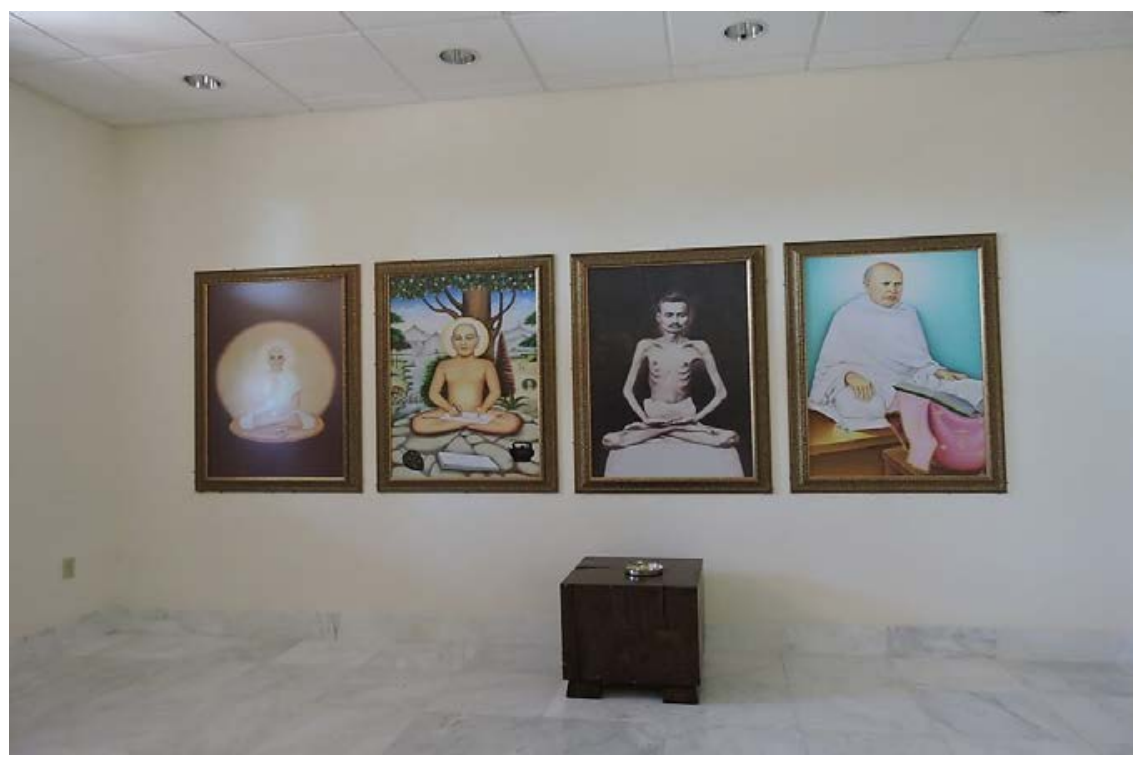

Figure 24. Meditation Hall with the visuals of prominent spiritual teachers and ascetics of different Jain sects at Jain Center of Greater Phoenix

The Temple of the Jain Society of Metropolitan Chicago is a large temple situated in a lush green compound of the society. The temple building has two floors and has dedicated areas for major sects and sub-sects. The temple has a main worship area, which has a similar arrangement as the temples of South Florida and Phoenix. For example, the main platform has multi-sectarian images of the Jinas and the side-platform has images of the Jinas representing both the major traditions (See Figure 25). However, this temple building represents a creative innovation in its entire structural plan as well as in its rich visual culture. The temple has adopted two methods to invent a new form of Jain visual culture. The temple has a prayer hall, which the community uses for common prayers, lectures and meditation activities. There is one upāśraya, Śrimad Rājcandra meditation hall (see Figure 26) and library; a general library; dining hall; and a big unit of rooms specifically dedicated to the pāthaśăla activities. At a visual level, the temple displays posters and pictures of different sectarian schools of thought and philosophical 
confluences of the sectarianism. There are many posters that present multi-sectarian and canonical and non-canonical Jaina texts. Such visual culture gives the sense that the temple is imbibing and depicting doctrinal negotiations through a new form of visual culture (see Figure 27). In addition to demonstrating the sectarian presence and visuals that demonstrated a sense of sectarian negotiations; I observed that the temple emphasizes the displaying of the face of Jainism. Since the temple is situated in the city of Chicago the community has erected a bust size statue of Vīracand Gāndhī. The Jains at this temple explained why they have the image of Vīracand Gāndhī at the temple. According to the Jains, Vīracand Gāndhī represented Jainism at the first World Parliament of Religions in 1893 in Chicago and his speech was about Jainism in general; and not about any specific sect of Jainism. Therefore, the Jain community members consider the image of Vīracand Gāndhī at the temple to be a symbol of an all-inclusive Jainism (see Figure 28). According to Jains at this temple, the unity among the community is better conveyed through visual and structural arrangements than through the ritualistic expressions. 


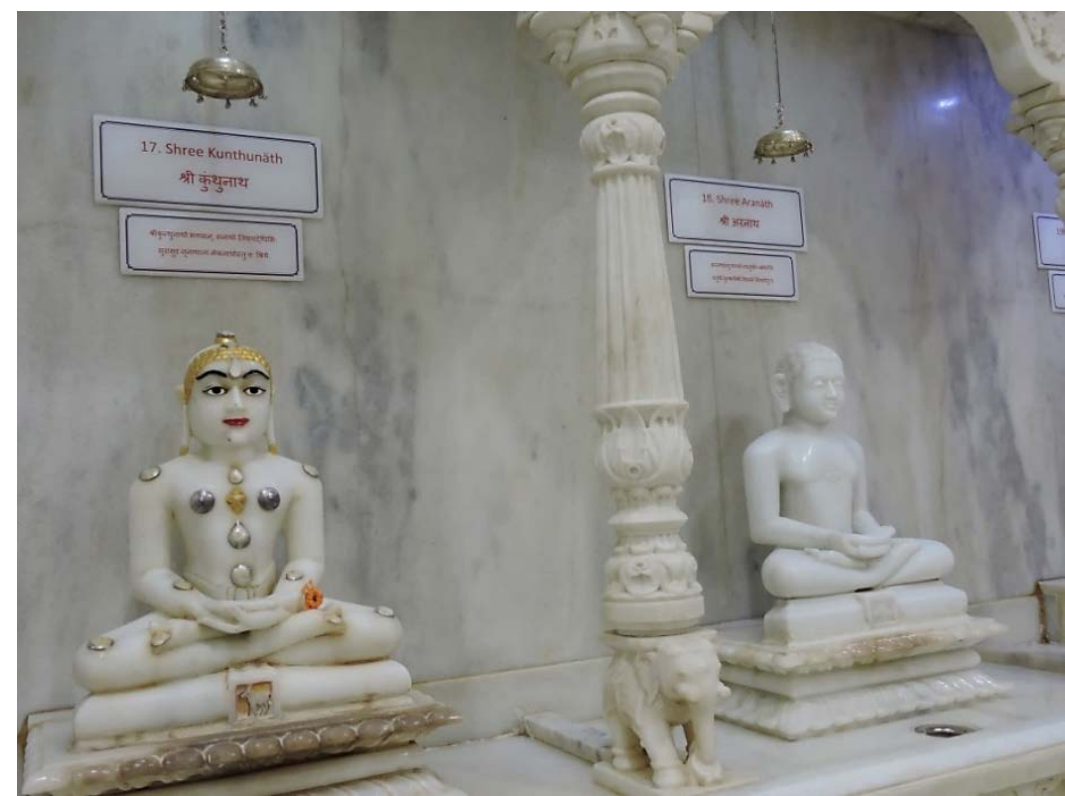

Figure 25. Two images of Tīrthankaras (the Śvetāmbara and the Digambara versions) sitting at the side platform of the temple at Jain Society of Metropolitan Chicago

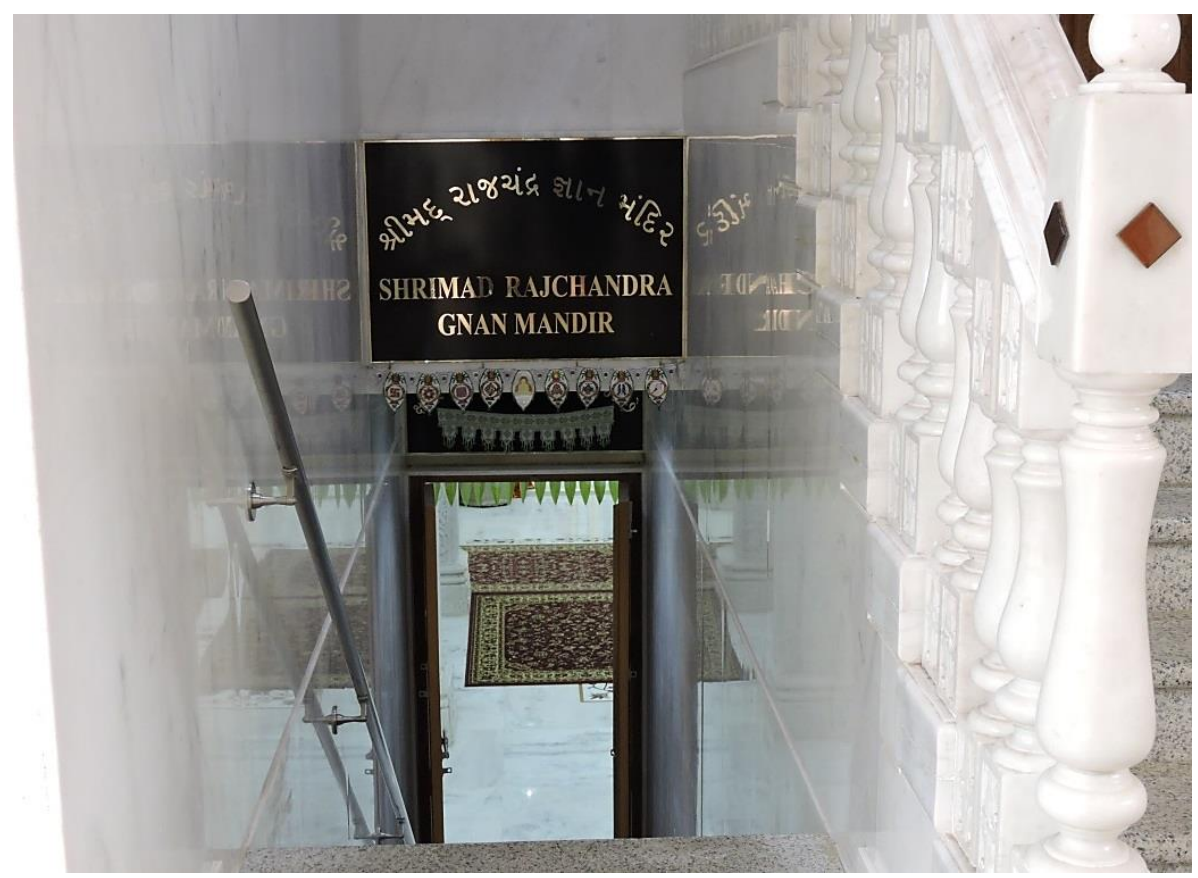

Figure 26. Śrimad Rājcandra temple at Jain Society of Metropolitan Chicago 


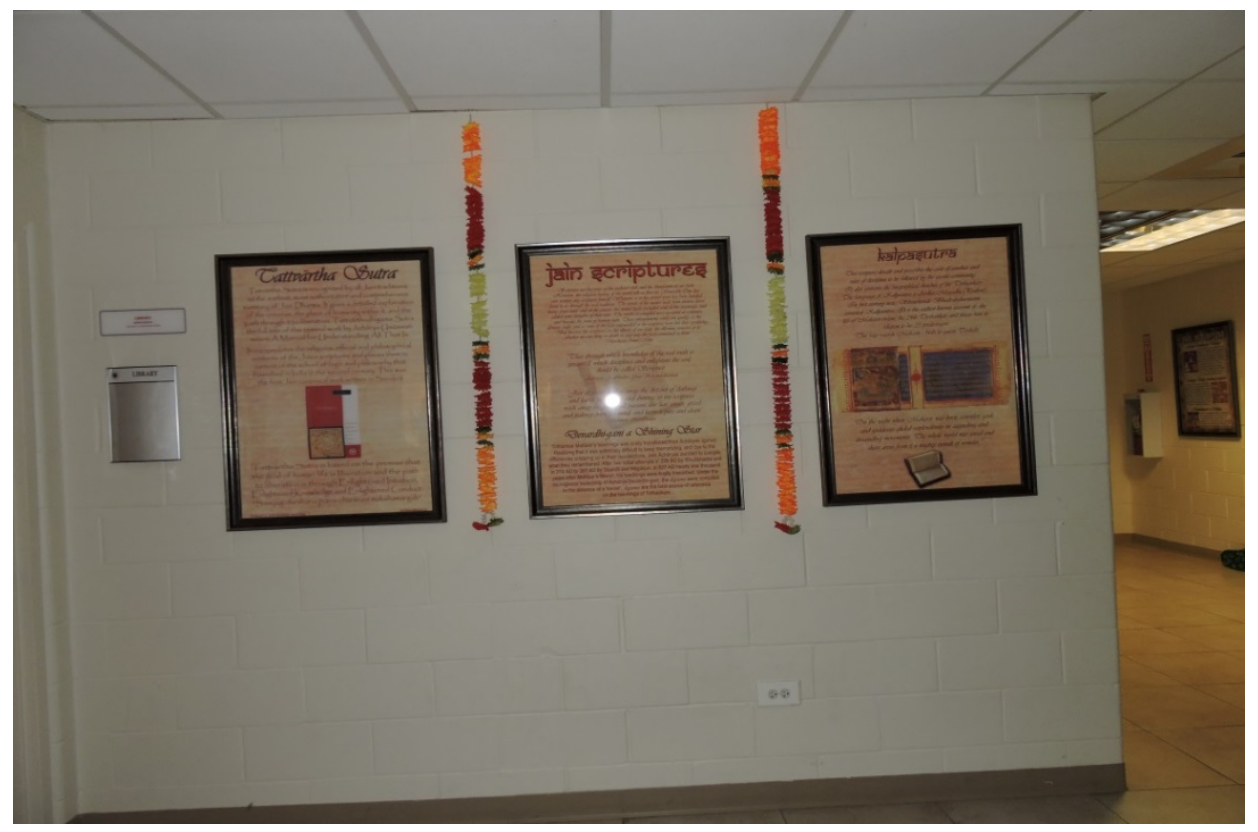

Figure 27. Posters about basic details of multi-sectarian canonical and non-canonical scriptures at the Jain Society of Metropolitan Chicago

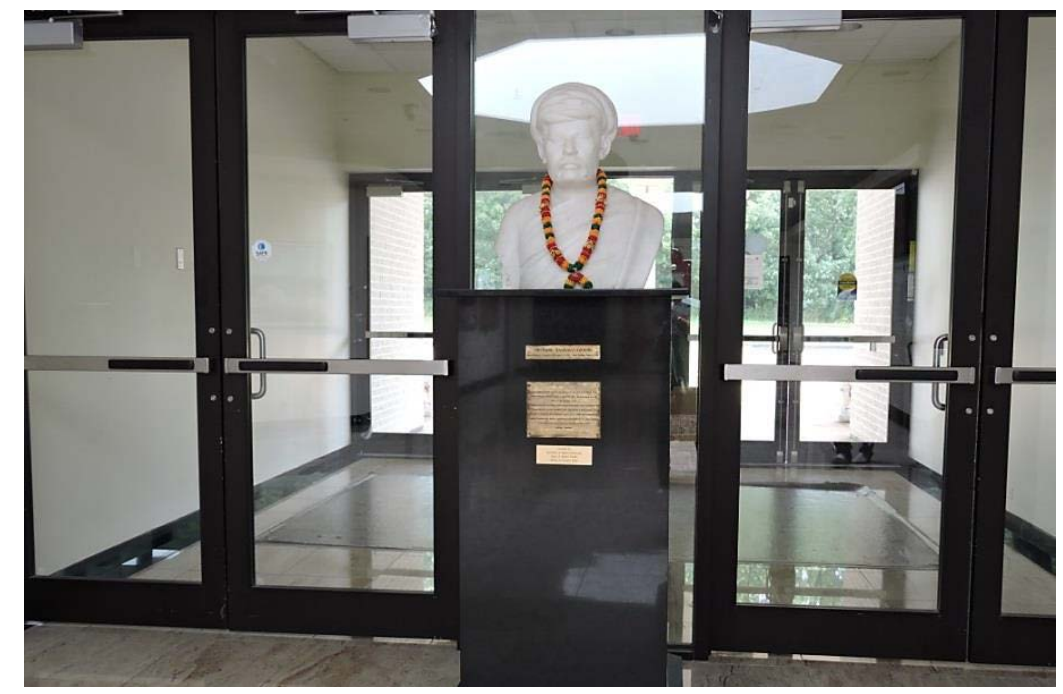

Figure 28. A bust-size image of Vīracand Gāndhī at Jain Society of Metropolitan Chicago

Now I turn my attention to the invented tradition of the Jain Center of America at the Jain temple in Queens, New York. “Unity in Diversity”, is how the Jains affiliated with this temple capture the idea that underlies their actions. The temple building, located 
in the middle of the residential area of Queens received the "Best Religious Building” award in 2005 in Queens, NY, a borough known as the "Mosaic Melting Pot of America." ${ }^{22}$ The temple building has a different pattern of invented visual tradition. The temple is a complex with four floors. Each floor is dedicated to a different Jain sect. The cellar of the temple has a multipurpose hall, a youth center, a children's room, a mini theatre and an art gallery that shows multi-sectarian art works on a rotational basis. The second floor has a Śvetāmbara temple and upāśraya for the Sthānakvāsīs. The third consists of the Digambara temple and Śrimad Rājcandra meditation hall and a library. The fourth floor of the complex has the Dādāwādî ${ }^{23}$ temple, the Aștāpad Mount ${ }^{24}$, a community dining hall and a kitchen. The rich structure vertically connects the different Jaina sects. According to the Jain community members, the temple is conceptualized using elements from various traditions of Jainism and centered on the Jain principle of anekāntavāda. For the Jains visiting this temple on a regular basis, the temple, a single unit with diversity of various sectarian traditions, is like a home. The Jain community here does not see the temple in compartments. I observed during my visits to the temple that though the sects and sub-sects are located on different floors, the Jain worshippers are equally engaged socially in inter-sectarian interactions and exchange. The Digambara worshippers visit the Śvetāmbara temple and vice a versa. The non-image worshippers do not cease from engaging with each other in the temple activities. A large number of the Jain community members who cut across all the sects attend the religious lectures

\footnotetext{
${ }^{22}$ Information as obtained by the President of the Jain Center of America; and the Center's official website.

${ }^{23}$ Dādāwādī (also Dādābādī), the 'Garden of Dādā is a temple monument dedicated to Jindatta Suri after his death at Ajmer. Jindatta Suri was the Jain ascetic from the Jaina Khatar Gaccha (group) teacher lineage.

${ }^{24}$ A mountain where Lord R̦șabha, the first Tìrthankara attained liberation.
} 
organized at upāśraya. I was introduced to Dr. Shah, an elderly Sthānakvāsī Jain lay male, who, according the Jains of this community-center is "actually the motivator and initiator" of this temple complex. Image worshipper Jains of this temple pointed out the inception history of this temple to explain their long heritage of the sectarian negotiations. For them a non-image worshipper Dr. Shah initiated the religious placemaking. Perhaps the most interesting innovative invention of the temple is the visual demonstration of the core essence of Jainism through more than five hundred posters, more than two hundred art objects throughout the temple. The posters, panels, and pictures are given systematic codes and themes such as essence of Jainism, Jain principles, Jain practices, Jain education and science, Jain history, pilgrimages, caturvidha-sangha and many more. The visuals do not highlight any one sect, but, show general and multi-sectarian information (See Figure 29, 30, 31,32).

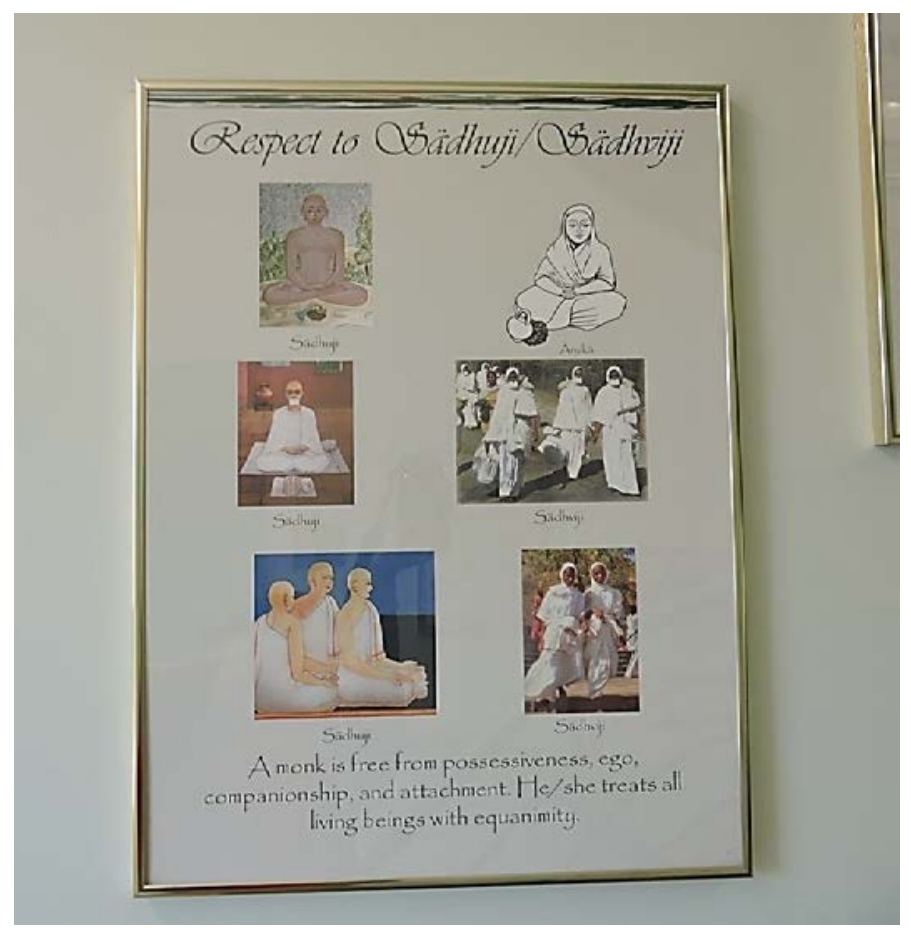

Figure 29. A visual poster of the ascetics from all sects, Jain Center of America 


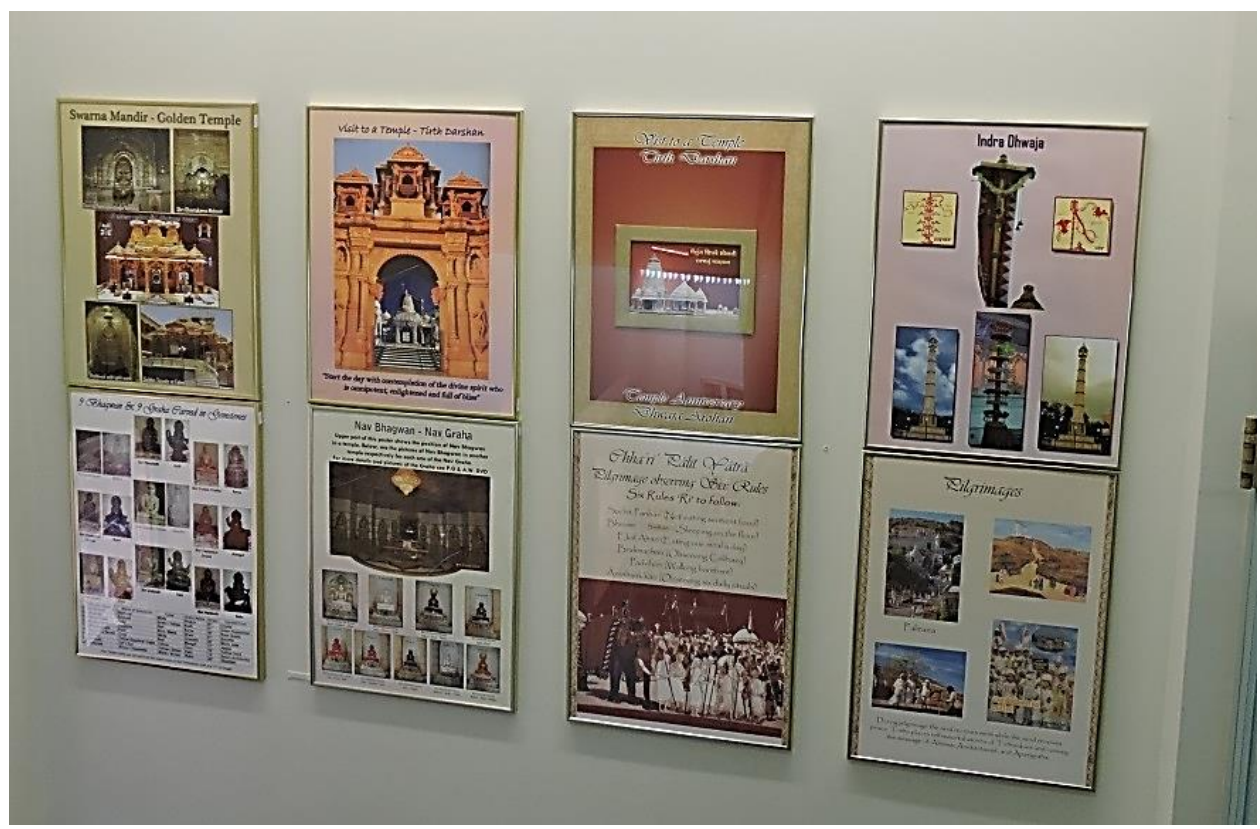

Figure 30. Visual presentation of multi-sectarian Jain pilgrimage places, Jain Center of America

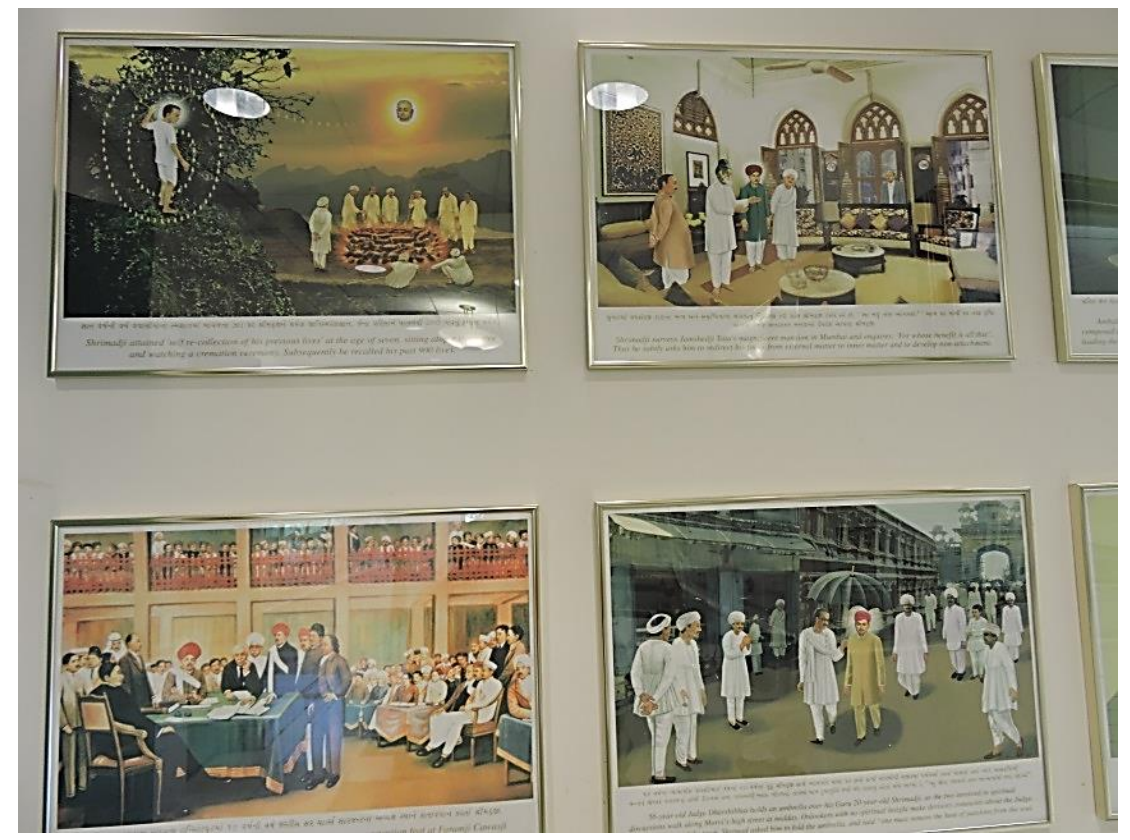

Figure 31. Visual presentation of Śrimad Rājcandra's life events, Jain Center of America 


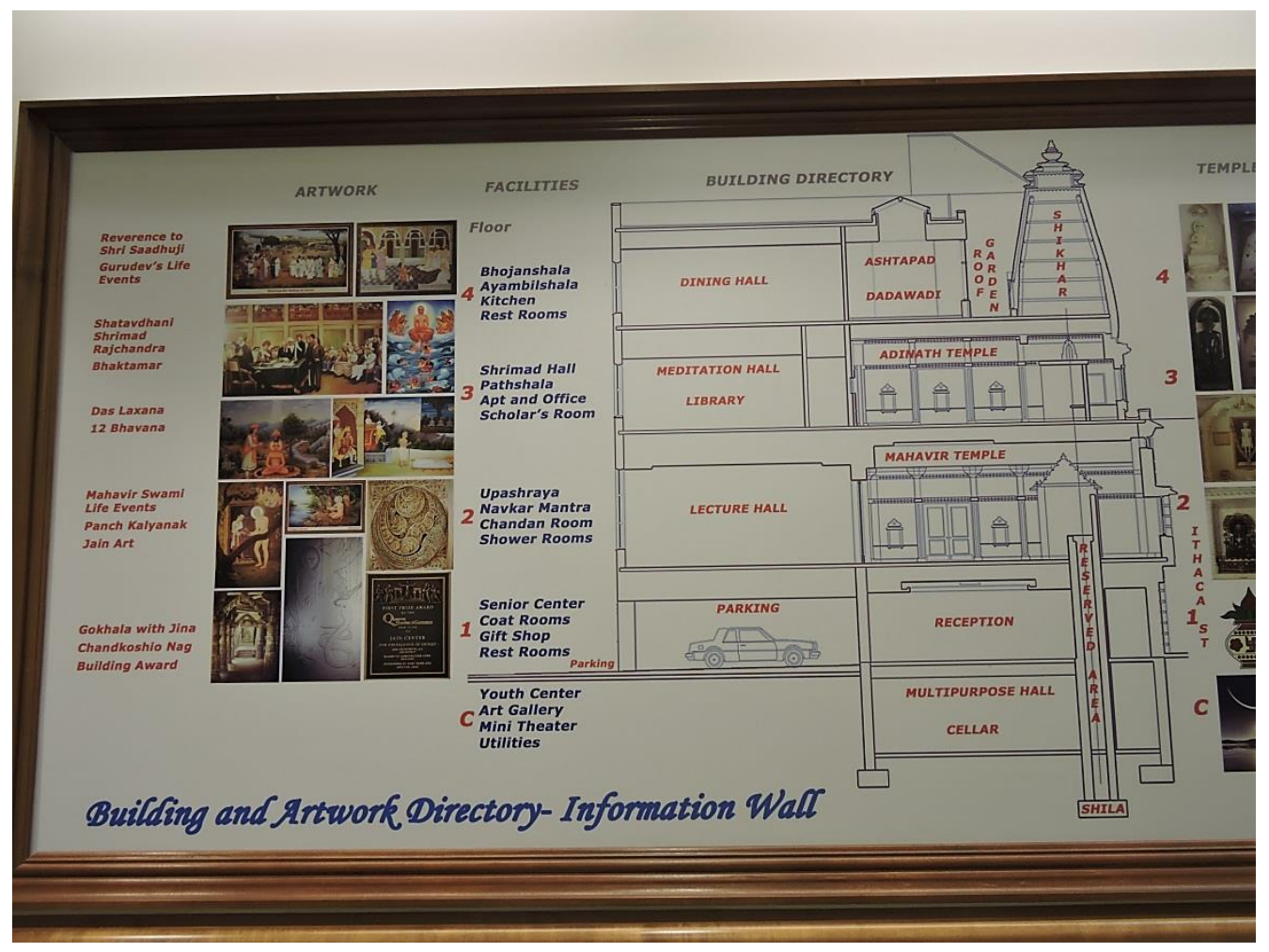

Figure 32. Information Chart of the multi-sectarian temple building, Jain Center of America.

I found out from my conversation with the Jain community members and management groups at the temple that the diversity of the visual culture is not just a reflection of a symbolic act of maintaining the diverse sectarian presence. For the Jains in the USA, incorporating icons and aniconic forms of visuals speak to their respect for the different belief systems within a larger Jain culture. This demonstrates the conviction of the community and its support for the sectarian interactions. The temple structures do not just accommodate the visual cultural representation of the two major sects, but include other sub-sects.

I analyze my observations and interviews and argue that each temple that I studied has a unique pattern of invention. The Jains in the USA do not just simply invent 
visual culture from the scratch. They use the old materials and traditions to create a new form of visual culture. Certainly, the sectarian negotiations are the core of the invention of a new form of Jain visual culture in two ways. The sectarian negotiations have encouraged the Jains to invent a completely new set of visual culture, but at the same time, the invented visual culture is facilitating the fostering of the bonds of unity in the community. I argue that place-making in the form of constructing a temple, which accommodates diversity of sects is the commencement of the invention. My conclusion is that a single temple is a combination of many temple traditions within it. The invention of tradition broadens its scope as the Jains begin to arrange and re-arrange the sacred materials, symbols and images to fit to meet their sectarian needs. My interpretation is that each temple brings different sectarian visuals together at the same place and arrange them into a presentation in such a way that those visuals become accessible to all across the sects. I refer to this arrangement as the creation of syncretic, creolized, translated, hybrid, alternate and cut 'n’ mix visual tradition (Vertovec 2000).

Moreover, I observed a pattern, which I also evaluate as a manifestation of the invention of tradition. The Jain community members at all the four temples have created various types of visuals that inform, motivate and uphold the sense of negotiations. The Jains have drawn out the necessary essence from the Jaina philosophy and religious visuals to construct novel visual identity of Jainism. This entails use of Jain philosophical symbols that run across various sects and demonstrate intersections of the doctrinal differences.

It would not be appropriate if I only analyze the invented visual culture. It is also important to discuss the Jains' reception of the new form of Jain visual traditions. All the 
four temples that I visited during my fieldwork have members from non-image worshiper sects. Indeed, the invented version of structural and visual culture accommodates the facilities for the non-image worshipers but I also found out during my study that the multi-sectarian arrangements of the temple have attracted non-image worshipers too. Many of the respondents informed me that they are familiar and comfortable with the visual forms at the temple. For the non-image worshipers, the images of the Jinas are not unfamiliar. When I asked some non-image worshiper Jains at the temple how they felt about their affiliation with a temple with images, one of the respondents shared her views with me in these words, "a temple with mürtis (images/idols) gives support. They enhance feeling of faith.” Being a Sthānakvāsī Jain who grew up as an iconoclastic, I could easily identify with the other non-image worshipers' sentiments at this temple. I could also sense the worth of religious visuals as a support in maintaining my faith in a diasporic context.

Moreover, many young parents from an image-worshipper tradition and nonimage worshiper tradition referred to the relevance of the visual presence as an important anchor for the future generations in their practice of the faith. One parent pointed out "it is good that we have a temple, mürtis and multi-sectarian visual culture, otherwise, we would have sent our kids to a Church in order to feel the visual aspect of religion.” Another parent asserted that this diversity of visual culture is a good opportunity for children to learn about various sects. For many parents, this invented version of visual culture serves as a religious teaching tool that speaks to a specific ethnic need in a diasporic context. Some parents shared their experiences of how the visual culture piqued the curiosities of their children. They told me of how their children would ask 
questions such as "Why there are differences in the iconography of the images of the Jinas?” The parents said they used such questioning as an opportunity to deepen their children's knowledge of Jainism. "Since you live in the sectarian negotiations and you would like the future generations to maintain the unity, then, how do you educate the children about the differences without they see?” I would probe further. The diversity in visual culture at one place is a tricky matter for the parents to explain to the children in the setting that calls for stringing the sectarian negotiations. The parents said they taught their children about “diversity” within Jainism, and depended on the pạthaśālā, to teach them other aspects of Jainism. I will discuss the role of pāthaśālā in detail in the next chapter. Away from the homeland and living as a minority community, the Jains view the importance of the temple and the sectarian blend of visual culture much beneficial to the nurturing of the culture of religion in their children. I observed that the invented Jain visual tradition has extended benefits for the young generations. On many occasions, I saw children performing darśana of images across different Jaina sects in the temples I visited.

\section{"I do all kinds of Püjās": The Invention of a Ritual Culture}

When and how did the Jains in the USA invent ritual cultures? Do the sectarian negotiations play any role in the creation of a new form of Jain rituals for the diaspora Jains in the USA? What is the nature or shape of the invented version of ritual culture by the Jains I studied? I meditated on these questions and tried to analyze the actions performed under the broad umbrella of ritual culture through my positionality as a nonimage worshiper Jain form India. I soon began to realize that coming from a nonworshiper gave me a better prospect to understand the diaspora Jains’ world of ritual 
culture because it made me an impartial to judge of the concept of ritual in the form of $p \bar{u} j \bar{a}$ or $\bar{a} r t \bar{l}^{25}$. I gathered data from my personal experiences, observations and interviews by using Geertz’s (1973) method of thick description; I observed the phenomena of the sectarian negotiations playing out in the diaspora Jains' invented ritual cultures. I define myself as one holding a position of semiotic endeavor in analyzing and interpreting the Jains' ritual in diasporic context by using collected data to interpret their ritual experiences and practice (Geertz 1973: 27-28).

In this section, I mainly focus on how rituals are invented in various forms and at different levels such as cross-sectarian engagements and exchange. In order to give a better interpretive description of my research I have used the conceptual explanation of "ritual as action" and "ritualization" offered by Humphey and Ladlaw (1994: 5). Their casting of the concept of ritual as action and ritualization fits well with my elucidation on the ritual culture invented by the Jain community in the USA. According to Humphey and Ladlaw "In ritual, the celebrant has agent's awareness of his or her action...the discursive quantity of agents' awareness of their action, which can be grasped from the perspective of the qualitative view of action in general, we shall call the ritual commitment or stance" (1994: 5). Ritualization as Humphey and Ladlaw define it is "an agent's adapting of a particular attitude to his or her action, and enacting what he or she does, therefore, in a particular, qualitatively transformed way” (1994: 5). I use the concept of ritual as action and the idea of ritualization to evaluate the invented ritual culture of the diaspora Jain community.

\footnotetext{
${ }^{25}$ An act of worship in which a small oil lamp or round-shaped dish is waved in front of a sacred image
} 
The concept of invention of tradition does not exemplify creating something out of nothing but it entails re-organizing and re-constructing new forms using old ideas and materials. To begin with, I argue that the first noticeable instance of invention of tradition in the form of ritual culture is the design of the ritual space in temples. All the four temples that I studied have a common main platform on which the icons of the Jinas (the Śvetāmbara and the Digambara) are located. Therefore, the Jains, from different sects perform their rituals in a common physical zone. The multi-sectarian rituals are performed in the physical arrangement of invented hybrid visual culture (See figure 36 and 38). The Jains in the USA do not eliminate the concept of performing $p \bar{u} j \bar{a}$ according to a person's sect. However, the rigid concept of performing the worship in sectarian specific temple is replaced with the invention of a multi-sectarian space for worshipping. What seems to be happening here is that the Jain temples have introduced the idea of pluralistic versions of Jain $p \bar{u} j \bar{a}$ in order to respect each sect's individual needs, in keeping with their notion of the sectarian negotiations. In order to provide the sectarian space for $p \bar{u} j \bar{a}$, the Jain communities have devised a schedule, in which different timeslots exist for specific sectarian worship sessions. I observed that only a few Jains worshippers from the two major sects perform their ritual actions as per the normal timeslot. Nonetheless, this scheduling of a time-slot for sect-oriented worship does not suggest that members of that sect only attend a particular sect-specific püjās. I observed that the creation of a common space for worship actually have affected crossover participation in the rituals. Even though a few members would continue to perform their sectarian $p \bar{u} j \bar{a}$, Jain community members from various sects participate in the shared worship sessions. The sectarian negotiation has produced the cross over worship culture. 
I argue that the invention of ritual culture is not simply demonstrated through the physical arrangements. It is also observable through the community members' mutual and reciprocal adaptation of rituals. Dinesh Jain, a young male worshiper from the Digambara sect who also teaches Hindi at the Chicago temple presented his views on the creation of a common platform for $p \bar{u} j \bar{a}$. For him differences in rituals are not important as they are (the Jains) are together at the same temple because of the sectarian unity. The unity among the sects is significant in that it creates a joint space for worship. The Jains visit the temple at the time of their convenience (mostly on Sundays in large numbers). They do not plan their visits to coincide with the time during which their respective sect's $p \bar{u} j \bar{a}$ or any other rituals are being performed. Many spoke at length about how their motivation to participate in cross-sectarian $p \bar{u} j \bar{a}$ has increased since the temple was built and a shared platform for $p \bar{u} j \bar{a}$ was created. These Jains have broken the rigid sense of exclusive sectarian ritual practice and have become more participative in multi-sectarian forms of the worships. Importantly, the children born in the USA are only familiar with this invented form of the Jain ritual culture. They specifically do not distinguish between the sectarian versions of $p \bar{u} j \bar{a}$. For them, the Digambara or the Śvetāmbara $p \bar{u} j \bar{a}$ traditions are just different versions of $p \bar{u} j \bar{a}$ but nothing more than that.

Manish Modi is a young male worshiper and a father of two young daughters. I interviewed him at the Jain temple in Chicago. He used the following words to describe the concept of a hybrid version of Jainism and its impact on crossover ritual participation:

It is an amazing model, this temple is like a university, and you can see various perspectives. I heard about Śrimad Rājcandra only after coming to the USA and at this 
temple. I was unaware of other sub-sects earlier. Such arrangement is also a good opportunity for the children to learn about different traditions and rituals. I do all kinds of püjās.

The non-image worshippers or followers of Śrimad Rājcandra who originally did not affiliate with any kind of rituals are now enthusiastically participating in darśana and $p \overline{u j} \bar{a}$. They accept the performance of rituals as an absorbing element of faith. As most Jains gather on Sundays at temple, they all participate in the rituals. Another instance of the inventiveness of the ritual culture is the communal performance of $\bar{a} r t i^{26}$ and mangaldīvo ${ }^{27}$ ceremony. A common ārti and the mangaldīvo is performed to the images of the Tirthankara in-group by the Jains from all the sects of Jainism (See figure 33, 34 and 37). The Jains from all the sects gather and recite a series of prayers praising the qualities of the Tîrthankaras. This ritual ceremony represents a multi-sectarian faith convergence.

Religious festivals and celebrations such as Mahāvīra Jayantī and Paryuṣaṇa are common to all Jain traditions. Yet, they are celebrated in different ways depending on the sects in India. In the case of the Jains in the USA, these celebrations are explicitly reconfigured. Practices of the religious festivals are invented to reflect the negotiations. All of the four Jain communities that I studied have re-designed the scheme of these religious celebrations. The entire Jain community in a uniformed fashion celebrates Mahāvīra Jayantī (see Figure 34). They take some elements of rituals from all the sects and customize them in an all-inclusive procedure of celebration. Most generally, the

\footnotetext{
${ }^{26}$ Act of worship usually with a small oil lamp on a thali (a plate) waved in front of the Jinas and other being worthy of devotion.

${ }^{27}$ Similar to ārti but performed with five-branched oil light.
} 
celebration of Mahāvīra Jayantī celebration includes recitations of a common nonsectarian prayer by children; group activities such as dance performance on any contemporary song composed to praise qualities of Mahāvīra; a short play or skit based on of any one core philosophical theme of Jainism; and a lecture or discourse by any invited scholar on any topic related to general principles of Jainism.

Another major Jain festival is Paryușaṇa. As I discussed in chapter 3, the duration of the festival varies from sect to sect. However, the Jains in the USA have come up with a new arrangement whereby the celebration of samvatsari takes place the tenth day, the day on which the Digambaras' typically celebrate it. All the four Jain communities have more members from the Digambara traditions. But these members accord to the negotiations and respect the needs of the minorities within their temples. . Pratikramana, a confession or a rite for casting off past sins (Banks 1992 and Humphey \& Ladlaw 2004) is an intense time for all who participate in it. Performances of pratikramana are presented in sectarian versions. Recitation texts are available in various regional languages of India. The confession is, mostly performed in the presence of ascetics or led by an individual (Banks 1992). In the case of the Jains in the USA, they have also synchronized the pratikramana session. In doing so, the methods and languages are blended and often supplemented by philosophical explanations. Parts of the pratikramana texts are recited in Gujarati and Hindi. The absence of ascetics is filled by the senior community members and sectarian versions of pratikramana are led by Jains from each traditions present.

The Śrimad Rājcandra movement has a marked success among the diaspora Jain communities (Salter 2006: 258). This is evident in each of the Jain temples I visited. The 
Jain temples prominently include Śrimad Rājcandra's tradition as an integral part of their spiritual and philosophical Jain world. The Jains in the USA consider Śrimad Rājcandra's emphasis and interpretation of self-realization and organizes satsang (religious gathering) or meditation sessions to exercise his philosophy and teachings. I argue that organization of the satsangs or meditation sessions is also an invented tradition as the Jains in the USA regard them as the essential part of the ritual culture for the Jains. The meditations and spiritual discussions directed by the teachings of Śrimad Rājcandra act as a backing for their sectarian negotiations. Devotees of Śrimad Rājcandra are less in number and mostly senior in age among the Jain communities I interacted with. However, Jains from different sects and specifically young Jains are now taking interest in the meditation and the satsangs (see figure 35). The meditation sessions and satsanigs mostly take place in the evenings during the weekdays and sometimes on Sundays. I argue that such activities of meditations and discussions laterally with the other rituals among the Jain communities have become part of an invented spiritually-oriented ritual culture. 


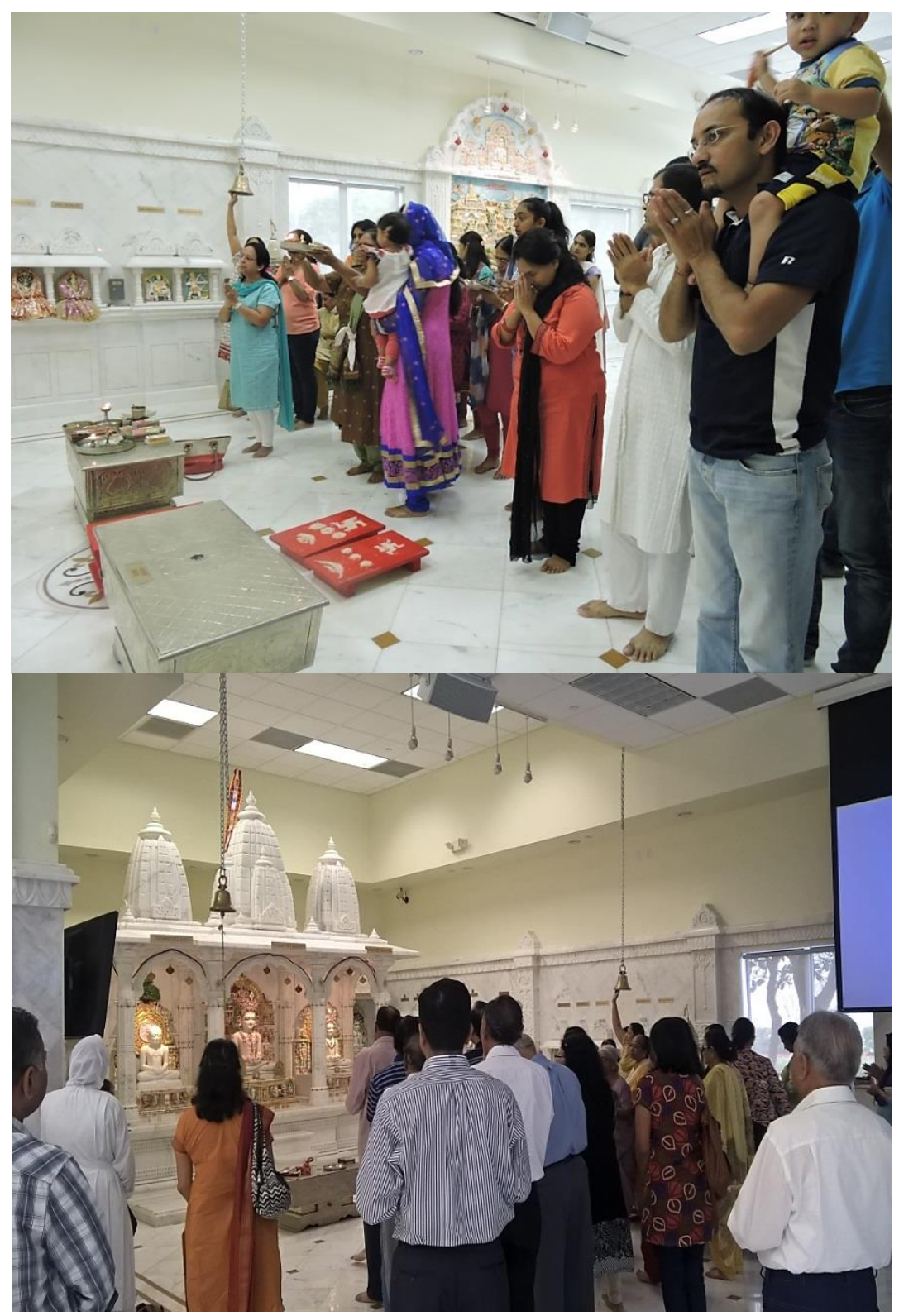

Figure 33. A common $\bar{a} r t i$ and the mangaldīvo performed on a Sunday by all the Jain community members together at Jain Center of South Florida 


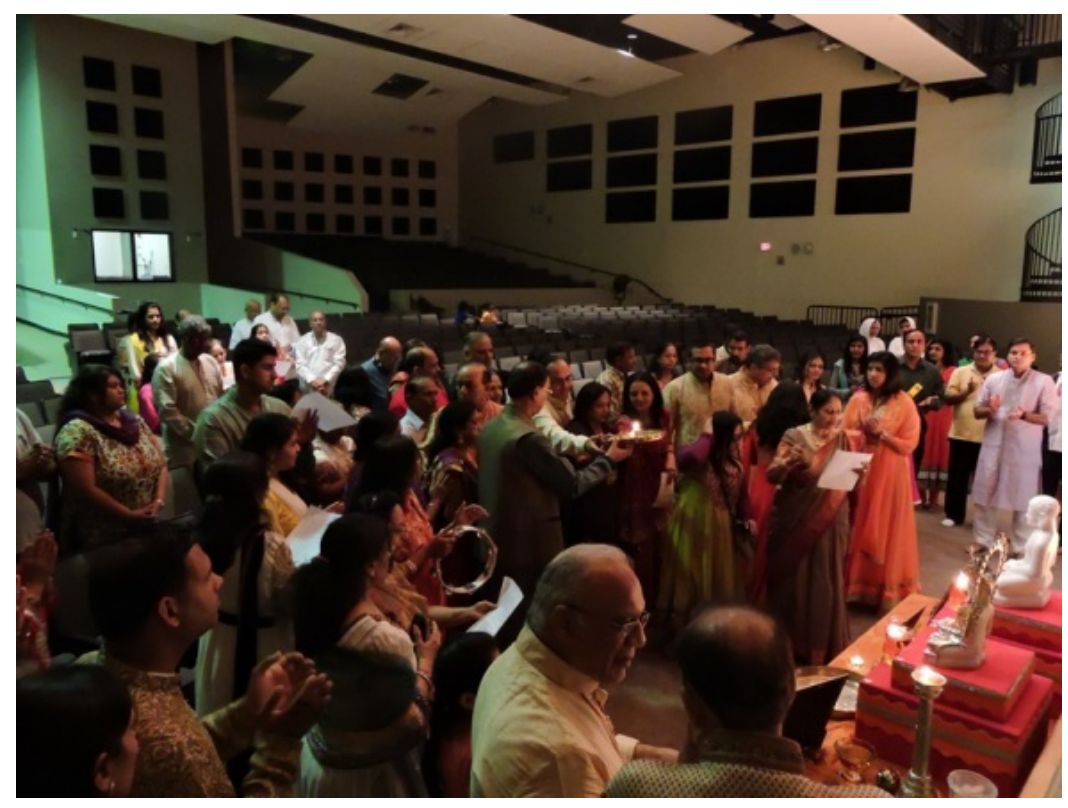

Figure 34. A common ārti and the mañgald̄̄vo performed by all the Jain community members together at Jain Center of South Florida during Mahāīira Jayantī celebration

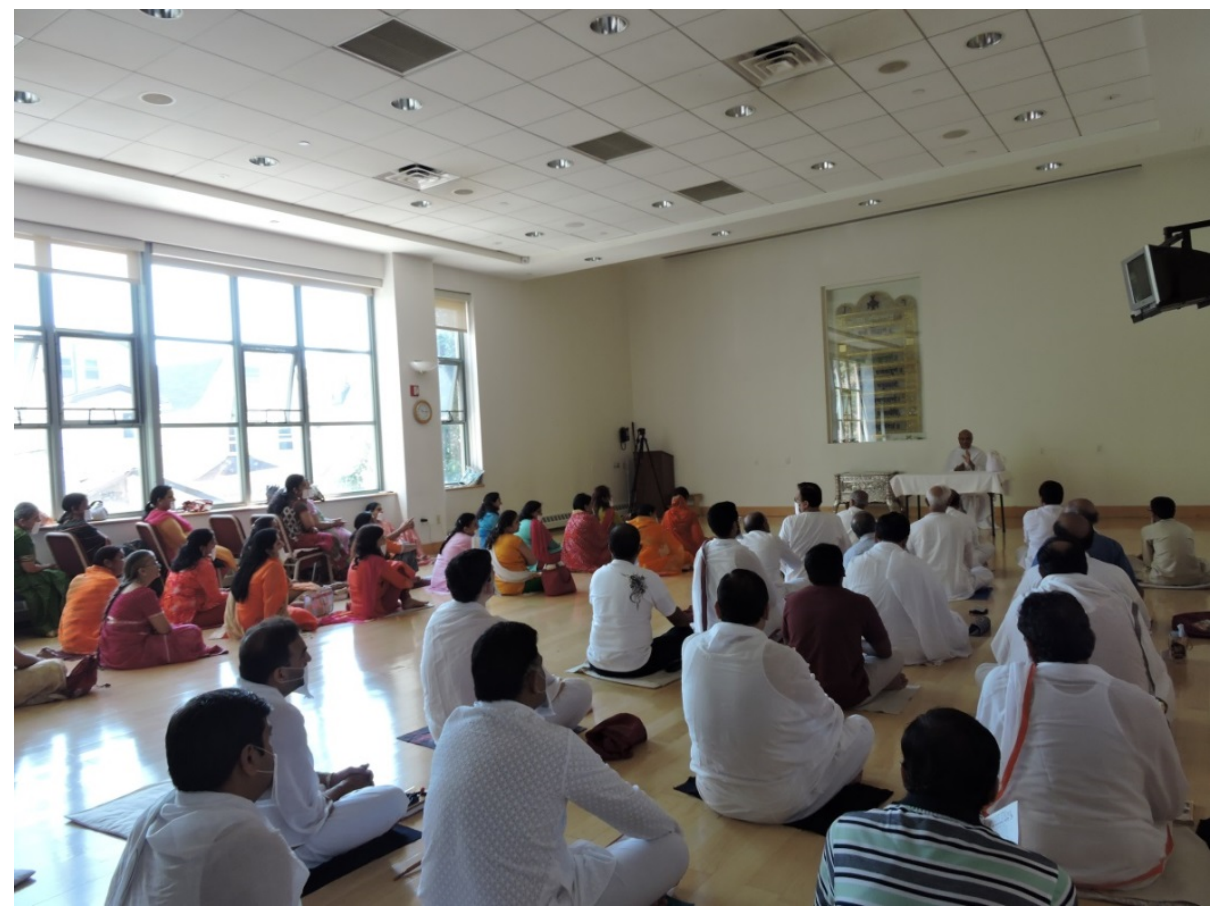

Figure 35. Satsaing lecture attended by the Jain community members from all the sects at the Jain Center of America-New York 


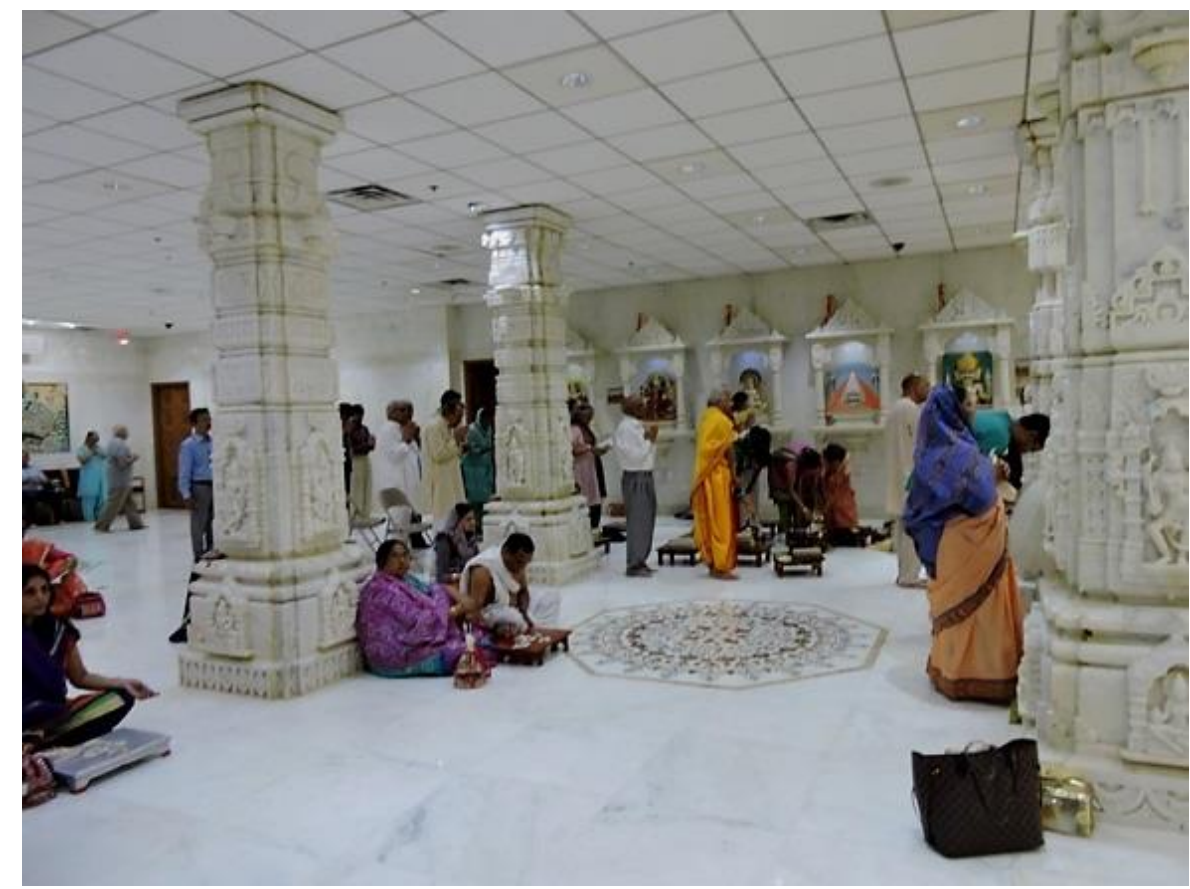

Figure 36. Multi-sectarian rituals and worships performed at the same time at a common shared temple by the Jains, Jain Society of Metropolitan Chicago.

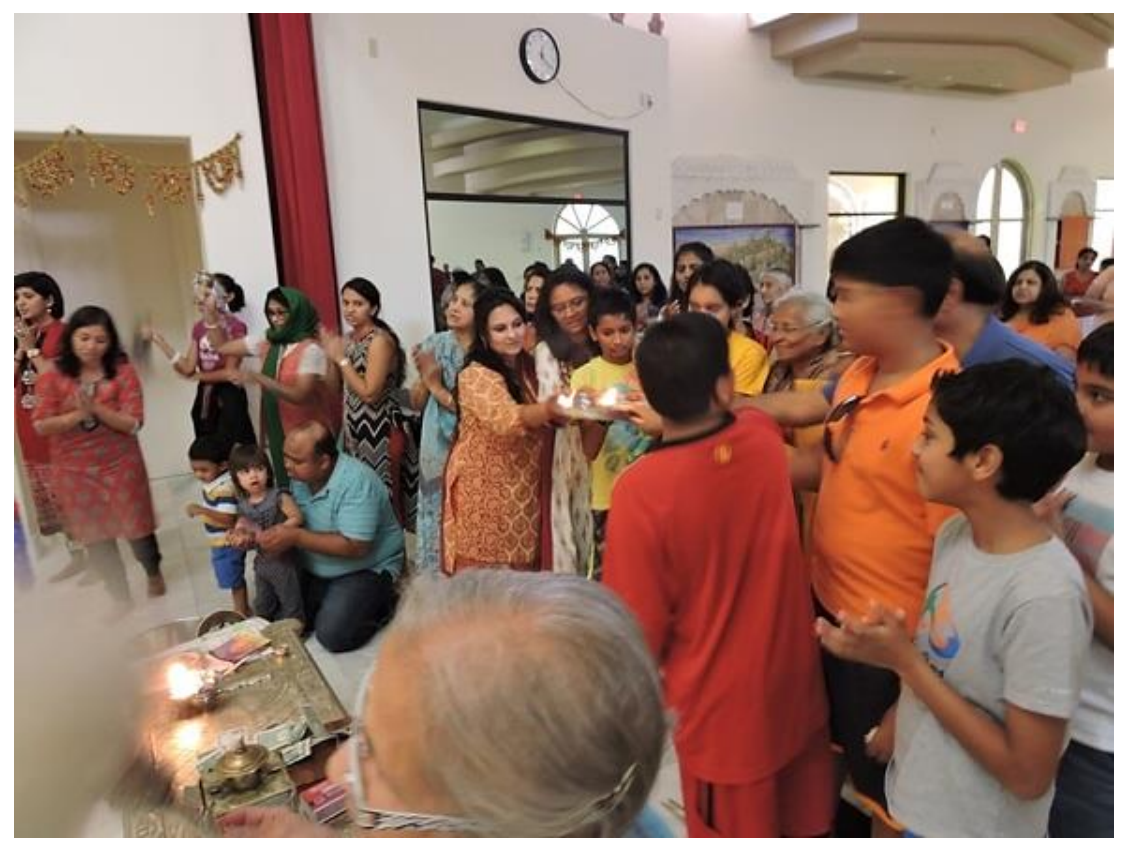

Figure 37. A common ārti performed by all the Jain community members together at Jain Center of Greater Phoenix 


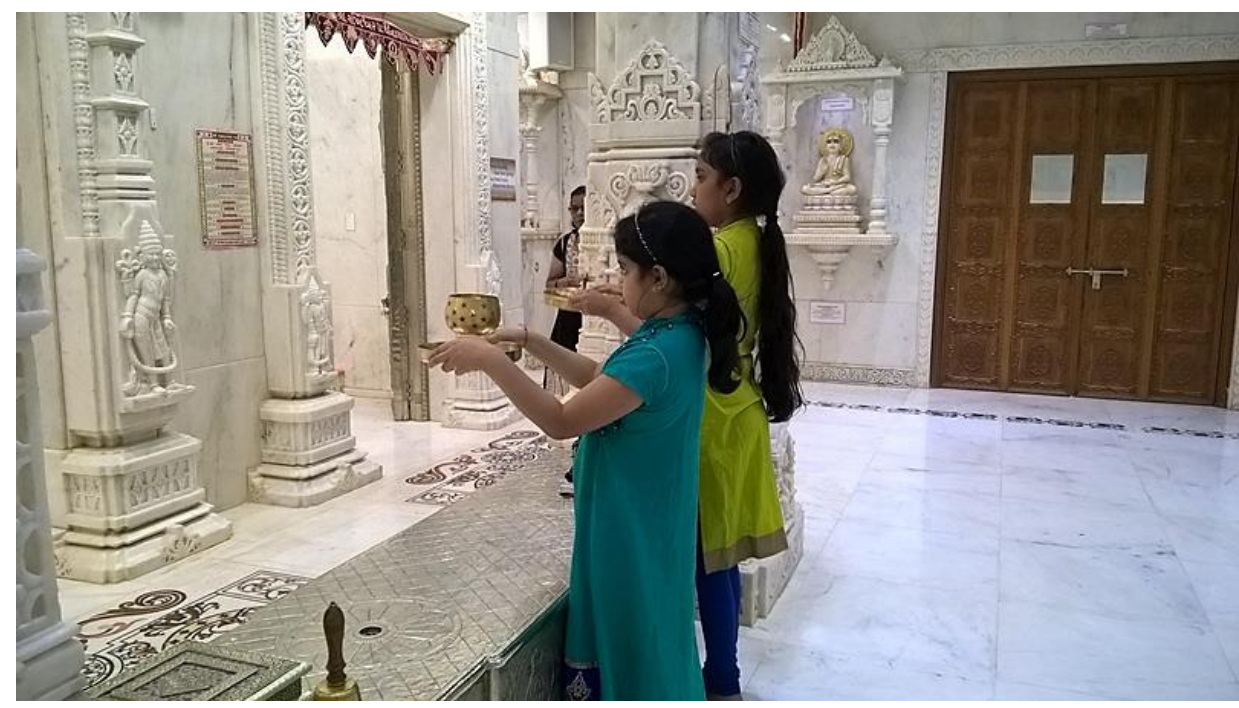

Figure 38. Young girls performing ārti in front of all the multi-sectarian images of the Tīrthankaras at the temple of the Jain Society of Metropolitan Chicago

The invention of tradition at the sphere of the ritual culture for the Jain community members is sectarian syncretism for the matter in which the Jains have developed a common religious place-making. As performed in close physical proximity, the rituals are invented in the form of spatial and temporal juxtaposition through syncretism. The invention of a new form of ritual culture is also has also occasioned invention in the participatory in the ritual. The Jains have multi-sectarian crossover acceptance and participation among the larger set of the rituals. The innovative practice of religious celebrations is a union of all the sects and dissimilar to the ways it is practiced in India. Multi-sectarian in nature, the invented ritual culture is all-inclusive and refashioned.

\section{Conclusion}

Started as part of the process of place-making, the temples with multi-sectarian presence, the invented tradition among the Jains in the USA expands its scope and plays out in the 
ritual-visual culture. The invention of tradition does not remain just all-sectarian but becomes inter-sectarian as it demonstrates hybridity in the visual and ritual forms. The reconfiguration exercises of creating spatial and ritual-visual is not just limited to the connectedness of the Jains' social worlds, but it has precipitated a new form of Jainism. The invention of tradition studied in my research validates how the Jains in the USA have acquired old materials to form a novel tradition at their temples towards continuing the negotiations. The crossover participation in the multi-sectarian visual and ritual culture by the Jains from various Jain traditions reflects how the invented tradition plays out at individual levels. 


\section{CHAPTER 6}

\section{Doctrinal-Philosophical Accordance and Invention of new form of Jainism}

\section{Introduction}

What remains important in a religious tradition for the people whose identity has been reshaped in diasporic conditions? Can religious doctrines continue to lead an individual's epistemological and behavioral attitudes in a socio-cultural environment that has been reconfigured? How does a diasporic context elicit invention of a tradition? With these questions in mind, I will discuss the Jain diaspora community’s thoughtful endeavor to carve a non-convention path to invent a new form of Jainism by deemphasizing, eliminating and re-creating the doctrinal differences which exist in Jain traditions. I discussed earlier in the chapter 3 how the sectarian splits within the Jain tradition have been prominently related to the doctrinal differences and vice versa for centuries. Moreover, the doctrinal differences have also been reasons for sectarian conflicts in India. A doctrinal interpretation can become normative for Jains to understand Jainism which means, a sectarian interpretation of a scripture or doctrine can shape the way a Jain of a particular sect may perceive the meaning of Jainism. For a Jain in India, a sectarian doctrinal thoughts and interpretation of scriptures become the epistemological tools to understand Jainism. However, I argue that the case of the Jains in the USA is different than in India. Since, the Jains in the USA have managed to create the sectarian negotiations; the negotiations and the diasporic conditions have caused and motivated the Jains to formulate new tools and methods to manage the doctrinal differences. I will demonstrate how the Jains in the USA have established accordance at the doctrinal level. In this chapter, I also argue that harmony at the doctrinal level and desires to maintain the 
sectarian negotiations have occasioned the invention of Jain tradition, that is, a new form of religion.

\section{The Sectarian Negotiations: the Need and Motivation towards Doctrinal- Philosophical Accordance}

The Jain diaspora community at the four temples that I studied has the presence of all major Jain traditions and sub-sects such as the Śvetāmbaras, the Digambaras, the Murtīpūjaks, the Sthānakvāsī, the Śvetāmbara Terāpanthīs; the Digambar Bīsāpanthīs and Terāpanthīs; and followers of Śrimad Rājcandra and Kānjī Svāmī. Moreover, there are Jains from various gacchs, castes (jāti/jñāti), languages, cultural backgrounds, and geographical affiliations. The sectarian negotiations among the Jains in the four communities and temples are managed throughout these broad range sectarian and cultural identities.

The negotiations among the Jains, which I have discussed in the earlier chapters, are demonstrated at the levels such as the construction of a common Jain temple, invention of ritual-visual cultures and formation of a formal Jain community. Here, it is important to recall that some of the main areas of dispute between the sects referred to different interpretations and question of authenticity of the Jain scriptures. The major divisions in the Jain tradition involve fundamental and sharp disagreement over the scriptures. The disputes are present in the form of differing opinions and beliefs about the origin, authority, authenticity and interpretations of the doctrinal matters (Folkert 1993:44).

By referring to these details, I point out to the context that as various Jain traditions come together at a common religious place in the USA, it is natural that the 
traditions transport with their sectarian doctrinal inheritance which have originated and developed in India. By looking at the nature, needs and importance of the sectarian negotiations among the Jains in the USA, I argue that the Jains found themselves in a motivating mood to reflect and re-think the disputes which pertained and caused by the doctrinal variations. I observed that the Jain communities that I studied desired to move beyond the spatial and ritual related negotiations in order to maintain and strengthen the bonds of unity. As the Jains commenced and progressed through the processes of the negotiations, they understand the positive effects of the togetherness. For the Jains in the USA, the negotiations prove be the catalyst agent, and allowed the community members to interact and exchange more frequently. As the Jains found the results of the negotiations beneficial, they became determined to elevate the negotiations one step further, which is, to the doctrinal-philosophical level. The Jains felt the need to strengthen the unity through mental and intellectual accordance so that the negotiations does not just remain feigning but the unity goes to the deeper level and more importantly, the bond continues to generations that would come.

In order to elaborate on the argument that this makes for the range of Jain diasporic phenomena in the USA, I use Vertovec's (2000) assertion that 'structure only' analysis is incomplete without considering a study of 'agency' that is, portraying social groups as action agents and not passive recipients of change wrought by overwhelming forces. Following the assertion made by Vertovec (2000), I assess the Jain community members' role throughout the processes of bringing changes in matters of doctrinal accordance. I argue that in the case of the sectarian negotiations, the Jain diaspora community members have played important roles on individual levels, which specifically 
leads my discussion towards the negotiations at doctrinal level. I also use Holy's (1987: 6) ideas of social reality as constructed through actors’ practical accomplishments and the meaning of social phenomena as resulting from actors' construction and negotiation of their interpretations, to demonstrate the role(s) of the diaspora Jains play in achieving the agreement at the doctrinal splits. In this regards, I will demonstrate the approaches and methods developed and used by the Jains towards a rationalized accord of doctrinal differences.

To begin, I will discuss individuals’ views and attitude towards the idea of establishing accordance at the doctrinal level. I contend that the Jains consider the sectarian negotiations as a prominent motivational factor for them to organize the unity through changing the attitudes and thinking. I conducted my first interview at the Jain temple of South Florida. It was not an interview by an appointment. The Digambara $p \bar{u} j \bar{a}$ was being performed as I walked in the temple as an ethnographer. There were a good number of community members participating in the $p \bar{u} j \bar{a}$ and a few were busy organizing the movable facilities at the center. I spoke with an elderly lady and expressed my interest in interviewing her. She suggested that I should rather begin by interviewing some younger community members and helped by introducing me to two young Jains, a male and a female (see Figure 39). The three of us sat on the chairs. I introduced myself and briefly described the purpose of the visit and research. I call it an interesting part of my fieldwork as it began by interviewing two community members from the two major traditions. After a long session of questions and answers, they shared with me the success "mantra", as they termed it as the success of the unity among the diversity. For them, not focusing on the doctrinal splits was the success behind the social solidarity and sectarian 
heterogeneity. Similarly, an elderly male, from the Jain community in New York referred to developing understanding of various vichār (a thought) as the required method for maintaining togetherness among the community members. By using the word vichār, he meant different schools of thought within Jainism. As I interviewed many Jains from various age groups and genders during my fieldwork, I learnt they shared a the idea that open-mindlessness over the doctrinal and scriptural differences is the approach to sustaining the unity which they have developed.

Moreover, both the first generation diaspora and the second generation diaspora hold the same views about the worth of deemphasizing the doctrinal conflicts in order to maintain the state of negotiations. The negotiations among the Jain sects in the USA suggest that the decline of customary patterns certainly change the tradition which is habitually interwoven. The Jain communities I studied hold prefer to reject the custom of doctrinal splits that present in Jainism and between the Jains in India. Diaspora Jains believe that unity is a more desirable condition than emphasizing the splits. For the Jains in the USA, the diasporic situations have brought them the needs to unite as a religious minority in order to be visible in the host community. Many Jains shared their views in reference to their position as a religious minority community and expressed that detaching from the doctrinal boundaries can further uplift the unity among the Jains in the USA. The Jains see doctrinal and scriptural matters as the reason for the divisional based bitter conflicts in India and they express the desire to refrain from it in the USA. It can be argued here that the sectarian negotiations for the Jains in the USA are more of a pragmatic phenomenon which deals with religious issues and concepts more sensibly and realistically. I observed that many Jains fear becoming lost within the host community by 
losing their cultural and community bonds if the negotiations will be shattered because of the interference of the doctrinal splits. In this regard, for the Jains as diaspora, reevaluating the weight that doctrinal matters can put on their religious understanding of the Jain tradition is also related to the needs of coming together as a common identity. The Jains find themselves as active participants in adopting a rational approach and reflecting upon the doctrinal difference for if it is really a major portion of the tradition or not!

I also observed that the Jains are conscious of their status as a minority religious community. They believe that arguing over the doctrinal differences will inhibit their ability to continue the mutual support they are enjoying through the sectarian interactions on social and religious sphere. It is important to point out here that their conscious awareness of their status as diasporic religious minority in the USA unceasingly prompts them to explore every method with which they can preserve the unity among the community. From my observations and interviews with several community members, I infer that the Jains as a minority community in the USA have been successful in placemaking, developing a common Jain identity, inventing an environment of the sectarian negotiation and creatively constructing a new form of ritual-visual culture. However, when I assessed intensely their responses, I realized that the Jains believe in managing agreement not only on the ritualistic front but most importantly on theological issues. I evaluate from my study that the Jains in the diasporic context consider their sectarian negotiations as motivating factor through which they achieve harmony at doctrinal level. I interpret form my study that there are two factors that is relevant for the Jains in the USA. First, the Jains emphasize on developing accordance for the matters that involves 
doctrinal and philosophical differences to avoid any conflict in the negotiations they have achieved, and second, they view multi-sectarian presence as an opportunity to re-visit the differences and re-construct them harmoniously. I will demonstrate other major methods and approach in this chapters the Jains are using to reach to accordance at philosophical and doctrinal level and how they have formed a new meaning of Jainism through it.

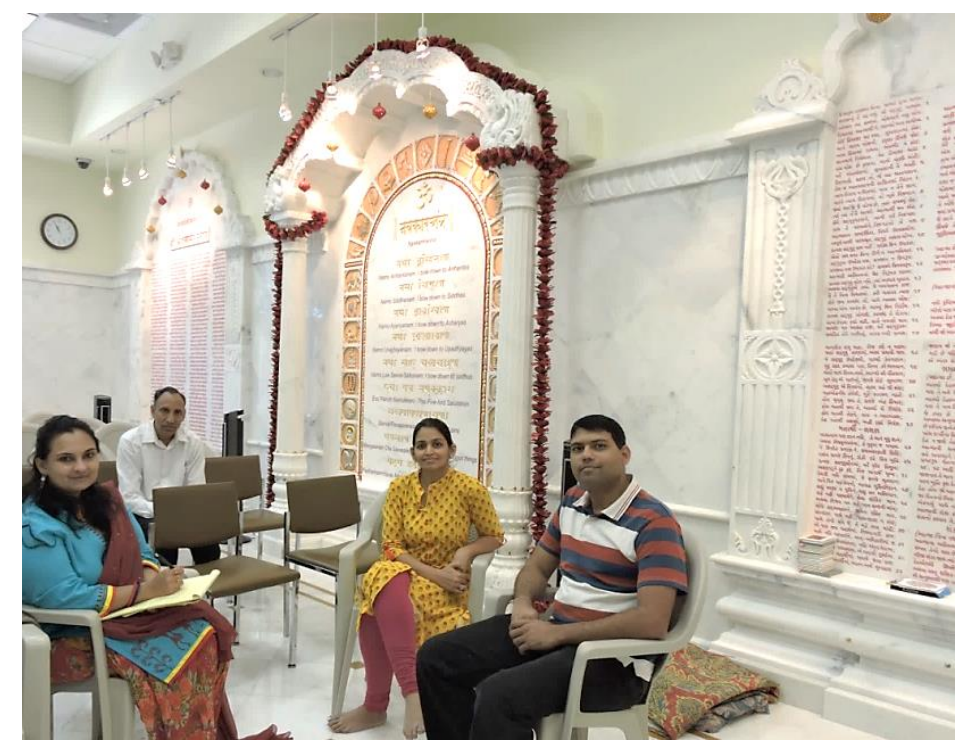

Figure 39. An interview session with a Digamabar and a Śvetāmbar Jain community member at the Jain Center of South Florida

Anekāntavāda, the USA Diaspora Jains’' Approach towards Doctrinal-Philosophical Accordance

How do people learn to be multicultural and open to diversity? What if one's own religion provides an epistemological method to develop a multi-perspectival view to accept the diversity? These reflective questions are answered by many of the Jains who I interviewed. "Why to seek help from outside when our own religion gives us a method to develop synchronization! We use anekāntavāda here (in the USA).” This was a reply by Jain women who I interviewed at the Jain temple in Phoenix. I observed during the 
interviews I conducted in my fieldwork that the Jains in the USA were referring to the theory of anekāntavāda more frequently than any other principles of Jainism in their conversations to demonstrate their rationalized attitude towards the negotiations. Before I discuss how the Jains consider the principle of anekāntavāda as a coherent method to sustain the unity, I will like to describe anekāntavāda briefly so that we can understand the Jains' selection of anekāntavāda as an appropriate method to be used in their diasporic context. Anekāntavāda is one of the cardinal principles of Jainism. Anekāntāa, literally means non-one-sided and $v \bar{a} d a$ is translated as theory, discourse, doctrine or thesis. Anekāntavāda lays emphasis on two points: first, characteristics of a reality or the object signify plurality; and second, many mutually contradicting characteristics of reality or of an object co-exists are all are valid from its point of view. Long (2009) describes it as, "the Jian doctrine of relativity" (141); and Padmarajiah (1986) defines it as, "theory of manifoldness" (7). It is also described as the doctrine of non-absolutism. The central theme of anekāntavāda is manifested through its noteworthy use in harmonization of conflicting views and upholding the validity of multiple viewpoints as true. Kapadia (1947) noted that, "When this ahimsā is allowed to play its role on the intellectual plane it teaches us to examine and respect the opinion of others. This implies that $a h i m s \bar{a}$ - the Jaina attitude of 'intellectual ahims $\bar{a}$ ' is the origin of anekāntavāda. In other words the Jaina principle of 'respect for life' (ahims $\bar{a}$ ) is the origin of 'respect for the opinion of others' (anekāntavāda)” (cxiv). He adds, “...This doctrine of anekānta$v \bar{a} d a$ helps us in cultivating the attitude of toleration towards the views of our adversaries. It does not stop there but takes us a step forward by making us investigate how and why we hold a different view and how the seeming contradictories can be 
reconciled to evolve harmony. It is thus an attempt towards syncretism” (cxix). Epistemologically anekāntavāda is used to understand that each object is made up of many forms, attributes, relations and modes; and thus self-contradictory traits of an object may co-exist simultaneously in the same object at the same time or even at different times.

According to the Jains I interacted with, anekāntavādic norm is the most useful method to understand that the differences can exist but can be accepted with an open mind. All the four Jain centers have a library (see figure 43 to 45 ) with a collection of books on Jaina logic of anekāntavāda. I was informed by the Jain community members that after coming to the USA, they developed a habit of reading different types of Jain literature, and specifically, books on anekāntavāda. However, I argue that this trend of reading about anekāntavāda is an effect of displacement. Some Jains informed me that it becomes essential to find out what is more rational and logical in Jainism if one must be updated with the concept of unity and intellectual harmony. For doing so, the Jains have developed interest in exploring anekāntavāda as a logical tool to analyze their attitude and behavior. I observed that the Jains' value the use of anekāntavāda as their learning device that aims at an attitude of the negotiations and doctrinal difference. I observed that they use anekāntavāda as their individual method to endorse unbiased view for different Jain traditions' doctrinal viewpoints. As many Jains shared with me, their use of anekāntavāda to develop multiple perspectives overtly lead to practice ahimsa. One community member from Jain temple, South Florida informed me that "I realized to focus more on an intellectual part in Jainism, which is anekāntavāda, I now learn about the diversity within us. Anekāntavāda has taught me a lot”. 
I argue that the Jains in the USA are a self-conscious group of a religious minority community who consciously strive to deal with their internal pluralism dynamics through various methods and approaches. I asked several questions regarding how Jains in the USA respond to the ideological disputes and doctrinal differences within the Jain tradition and what methods they use to approach the intellectual issues within the community. A Sthānakvāsī Jain lay woman from Phoenix who I interviewed on phone replied to these questions in lucid way:

There is no meaning in fighting for the intellectual or philosophical superiority since Jainism has the concept of anekāntavāda. Why can’t we use it! It teaches us that there are different paths. I respect various sects in Jainism, there are various methods to understand Jainism.

I observed that this diasporic Jains use anekāntavāda as a responsive tool to measure the differences exist among the various Jains groups in India over the doctrinal matters. For the Jains in the USA, it is extremely avoidable to fight over the doctrinal differences present in Jainism since Jainism itself in nature is anekāntik. I evaluate anekāntavāda as a religious normative theory which allows the diaspora Jains to determine a communion worth over the disarray.

For the diaspora Jains, anekāntavāda is one of the major concepts of Jainism for the reason it enable them to respect the sectarian negotiations and doctrinal difference in compare to their counterpart Jains in India. For the Jains in the USA, learning through logic is a prior possibility than to just focusing on the performance of rituals. I observed from my interactions with the Jains and found out that the community members of the Jain centers in the USA are a wealthy and educated group of people. I observed from their responses and talks that they don't feel it is appropriate to continue with the 
religious rigidity and intolerance since it interrupts their personal, professional, and social life which they don't want. Moreover, the community members gave me the reasons why they don't want to merely subscribe to just the negotiations at visual-ritual culture but to extend the negotiations at the doctrinal level. One among the many reasons they shared is their ability to rationally and intellectually understand the meaning of religion. They find its naïve to remain within the bucket of rituals in compare to find out certain intellectual aspect of Jainism such as anekāntavāda. They mention anekāntavāda as the method that help them develop their intellectual capacity to voluntarily understate the doctrinal disputes they in their natural course of migration carried out from India. I am tempted to evaluate the Jains' use of anekāntavāda with in terms of Hobsbawm's (1983) description of one of the elements of the invention of tradition which entails invention as the inculcation of beliefs, value systems and convention of behavior. I refer to the Jains' use of anekāntavāda as their invented value systems and convention of behavior to facilitate the inculcation of common Jain beliefs. The point here is that, seeking a philosophical foundation for the sectarian negotiations the Jains went back to their own tradition of anekāntavāda.

\section{Pạthaśälā: the USA Diaspora Jains’ Method towards Managing and Merging the \\ Doctrinal-Philosophical Variances}

As a Jain I have never received any religious education from pāthaśāla in India, but I have heard from my cousin, sisters, and brothers who attend pāthaśālā classes regularly about the moral and ethical teaching they receive there. Sometimes they come home with a vow that is designed to check some habits seen as unhelpful such as watching television as this can corrupt their moral attitude. As a person with a degree in 
Education and as a Jain, I could never rationalize how watching television for children can become an obstacle to developing good moral conduct. I did not intend to compare the Indian version of Jain pāthaśālās with the American version of pāthaśălās in my research. However, I was curious to find out how pāthaśālās in USA functioned and whether we can compare them to Indian pāthaśālās. This is the backdrop to my discussion here. From my several visits to the four Jain centers, I realized the best time for a Jain and an ethnographer to visit a Jain center is during the pāthaśa $\bar{a} \bar{a}$ hours. The centers have record attendance of the Jains during the pāthaśālă. Hence, a pāthaśāla offers the best opportunity to meet many community members. A pāthaśála is a religious education program or school. Banks (1992) mentions in his ethnographic study of the Jain community of a city in India that "In India, education in Jainism is achieved through daily instruction at pāthaśāla , parental guidance, and most importantly, guidance by the ascetics, either formally through vyakhyan (lecture) and sibir (camp), or informally through discussion in the upasraya" (188). The Jains in the USA do not have continues presence or direct interactions with ascetics, but they rely

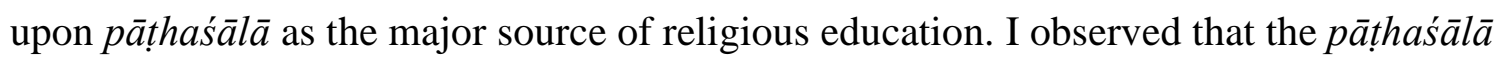
fills the void of the ascetics in many ways which I will demonstrate in detail. Moreover, I argue that the Jains in the USA have set unique objectives for organizing pāthaśāala which are managing and merging the doctrinal differences.

By assessing its purpose, structure and scope, I interpret pāthaśála as one more invented tradition resulting from the quest to meet needs and motivation precipitated by the sectarian negotiations among the Jains. As I discussed earlier in this chapter, the Jains desire to maintain the unity among the diversity of their community. Moreover, 
they also wish to approach the negotiations through eliminating the notion of the doctrinal difference. In order to attain these, the Jains in the USA consider pāthaśālā to be an appropriate method. I observed that the Jains seek to shift their focus from dogmatic religion teaching to the development of a balanced awareness about Jainism, which is free of the shackle of any sectarian or doctrinal disputes. This project entails educating the Jains about the core and non-sectarian principles of Jainism. I learnt from many interviews of the Jains who regularly attend pạthaśāla about the objective of such a religious educational program. For the Jains, a pạthaśāla is an efficient medium to maintain the unity and develop manifold viewpoints. In order to understand how a pāthaśālā can help the Jain community to build synchronicity, I purposefully interviewed young parents and elderly members. At the outset of my interviews, learning about Jainism came out as the most common answer. However, when I asked a male member from Chicago to elaborate on this response he told me that the pāthaśāla is like a "Jain Univeristy.” He added “the American version of pāthaśālā is different than India; In India, you can’t see other's perspectives but here (in the USA), you can. That's the benefit.” I take this answer as a summary of the objective of running a pāthaśâla for the Jains, which is, their collective and willing approach to retain the unity. It was still not enough for me. So, I assessed the curriculum they use at pāthaśâlās and I found out that the curriculum covers the learning elements that can help them to undermine the bitterness of the difference and facilitate developing values in spite of the differences within the various Jain traditions.

The pạthaśālās (See figure 40 to 47) at all four Jain centers run like they would at a university or school, well-structured and by the teachers who regularly receive their 
education to be a teacher at a pāthaśála (See figure 40 to 47). Moreover, the structure of a pāthaśāla includes the examination and graduation ceremony at the end of completing an entire range of courses. Classes are organized according a grade or a level which is similar to a formal school or university. It includes levels from toddler (from ages 3) to adults (31 and above). The classes are conducted in highly formalized manner. Each center has dedicated rooms for pāthaśālā. Every pāthaśālā has a library and collection of books on various themes regarding Jainism, meditation, etc.

I carefully studied the functioning of pạthaśāla by spending more time with the pạthaśa $l \bar{a}$-goers and teachers. From my observations, discussion and even attending one class, I argue that by organizing the pāthaśălās, the Jains intend to instill in their members a rational outlook towards Jainism. One center uses JAINA ${ }^{28}$ textbooks, while, three other centers have developed their own teaching materials to cover learning outcomes such as Jain way of life, Jain philosophy, basics of Jainism. The centers also organize group-discussion sessions and reading groups. Jains in groups study canonical scriptures, discuss and critique the commentaries and interpretations from them. However, attentions are paid to the non-canonical texts such as Tattvārtha Sütra and Samansuțta.

I interacted with many parents and spoke about the reasons for sending the young generation to the pāthaśālā. The parents were concerned about their children learning about Jainism, as the first reason, but they also emphasized how it is important for the children to learn to maintain the unity the Jains have developed. The parents believe that pạthaśāla can foster the value of unity in the young generation as they can

\footnotetext{
${ }^{28}$ JAINA is the federation of Jain associations in North America.
} 
interact with other community members and learn in a group about the diversity and common elements of Jainism. The Jain centers have prepared the curriculum keeping in mind the needs of the children for the fact they are aware with is that the third generation children, born in the USA who receive education in an American academic environment would not agree to be preached for the ritual-oriented Jainism. The parents and the teachers at pāthaśālass are aware of these diasporic settings in which their children are situated, and they do consider the diasporic settings as positive reason to educate the younger generation about Jainism with constructionist approach. To demonstrate what I have observed, I will use one of the responses by a parent:

Children ask many questions, since they go to local American schools, they always ask 'why', if they don't understand what and why they are doing, they do not agree doing it. If they comprehend Jainism, they develop real faith. We don't teach them about the difference, we make them aware of the difference as basic sectarian details. Pāthaśálā teaches them logic of Jainism.

As I discussed more with the children and adult community members who attend pāthaśāla classes regularly, I learnt that they are not taught about the sectarian differences per se. They do learn basic variations within the Jain traditions. The teaching is more focused on explaining core principles of Jainism, which they call “Essence of Jainism.” As I asked questions regarding how the teachers at pāthaśālās manage to keep the sectarian attributes of Jainism while teaching, Dr. Pradip Shah, a senior teacher at the pāthaśālās of the Jain center at Chicago talked confidently and asserted that "No difference while teaching, No sect at all, we did not want that way and so far we are successful.” Figure 43 shows a pāthaśálā teacher, places multisectarian visuals to elaborate the importance of unity through teaching at pāthaśâla , Jain Society of Metropolitan Chicago. 
I argue that the Jain communities in the diaspora value teaching Jainism to the young generation and adults so as to uphold Jainism as a culture and faith. However, the teaching offered at all the four Jain centered does not emphasize sectarian attitudes; rather, the teaching aims to develop a rational understanding of Jainism. I assess from my observations and interviews that for the Jains, a pāthaśāla is the intellectual backbone to carry forward the sectarian negotiations and reach to accordance at doctrinal differences by teaching logic and core principles of Jainism and lower in the weightage of doctrinal disputes, interpretations and variations. The curricula, teaching materials and approach do not emphasize the doctrinal or scriptural matters to be the guiding device to perceive the meaning of Jainism. Doctrinal matters are discussed only to inform the learners about it as one of the sections of Jainism. The emphasis of teaching is directed towards the principles and logic of Jainism. To demonstrate my argument, I will quote one incident. I spoke with a young energetic girl at the Jain center of South Florida after her pāthaśālā classes and as I asked her about what have you learnt so far, she was enthusiast to share with me that she is studying the "types of knowledge described in Jainism”. For the Jains, the pạthaśālā help balance the differences and fills the void of the ascetics. Moreover, the pāthaśăla is a platform through which the diaspora Jains can receive learning not just about Jainism but through Jainism to sustain the sectarian negotiations as an "intellectual unity" as described by Dr. Mukesh Doshi, the chairman, Jain Society of Metropolitan Chicago. 


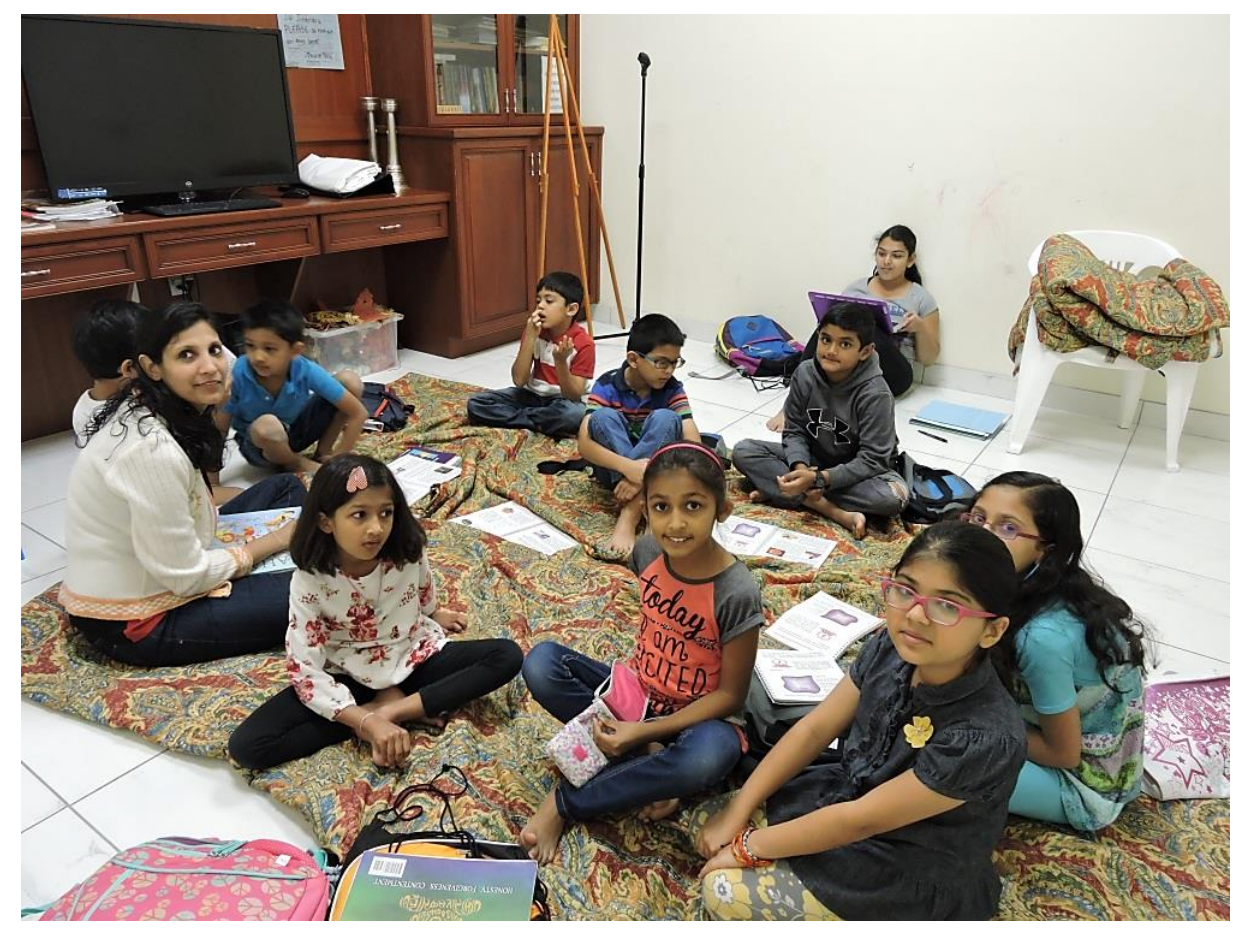

Figure 40. A pāthaśālā class at the Jain Center of South Florida

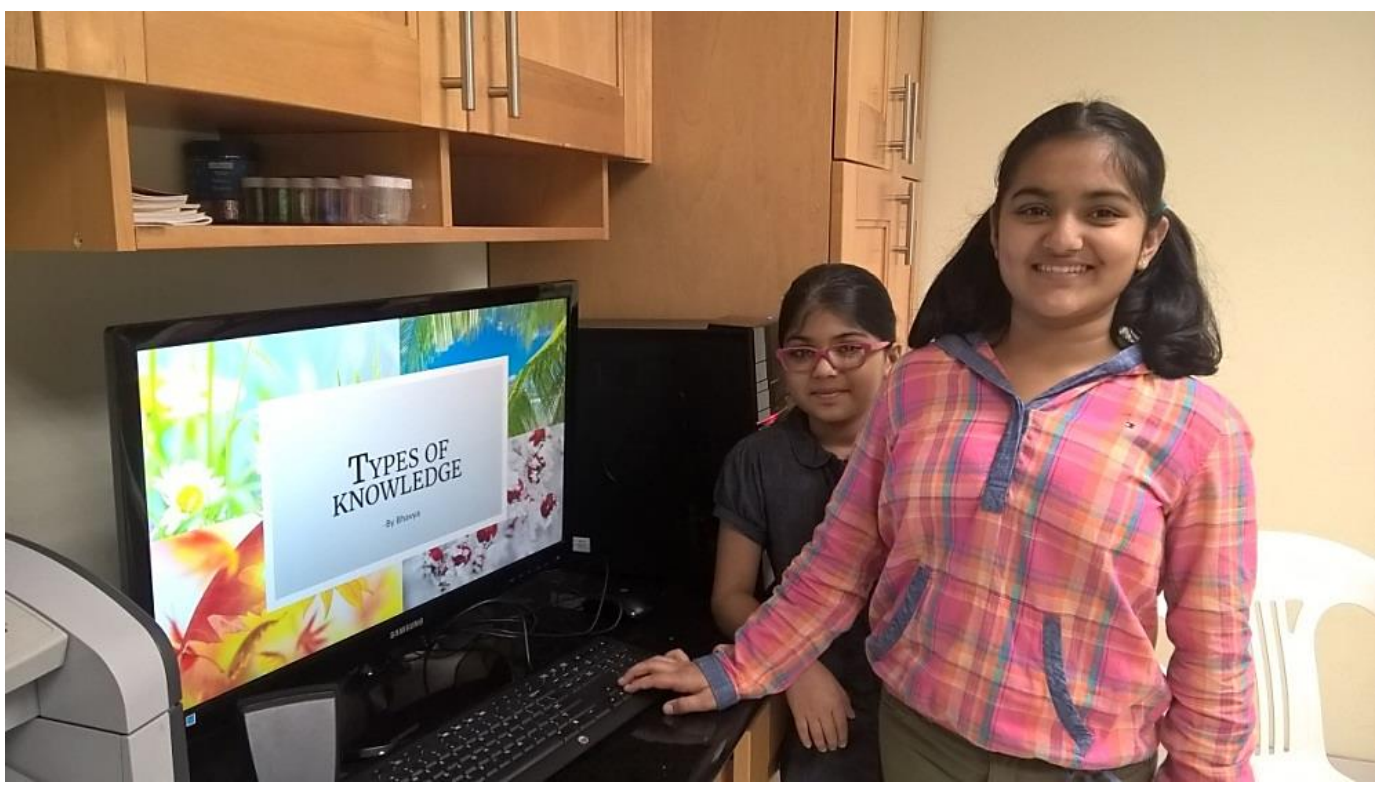

Figure 41. Pāṭhaśālā students explaining me the types of knowledge in Jainism at the Jain Center of South Florida 


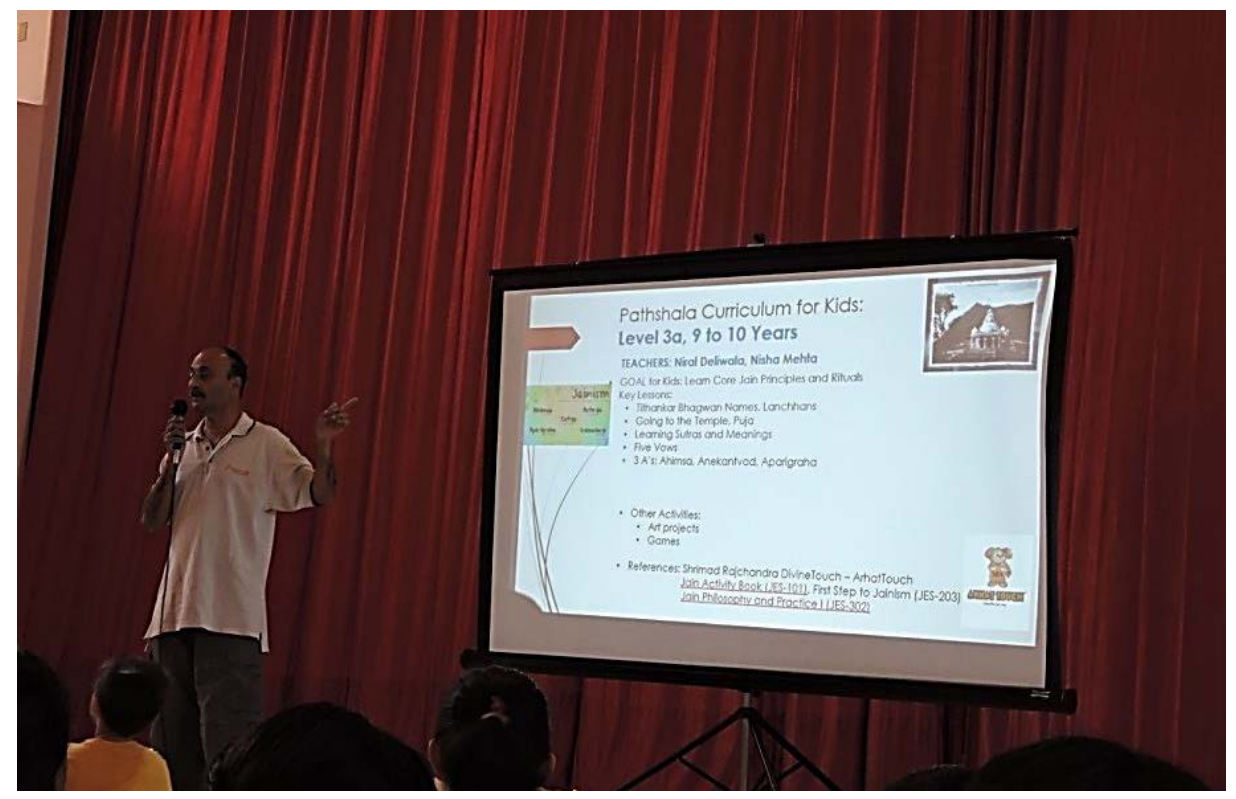

Figure 42. A pāthaśālā teacher explaining the curriculum at the Jain Center of Greater Phoenix

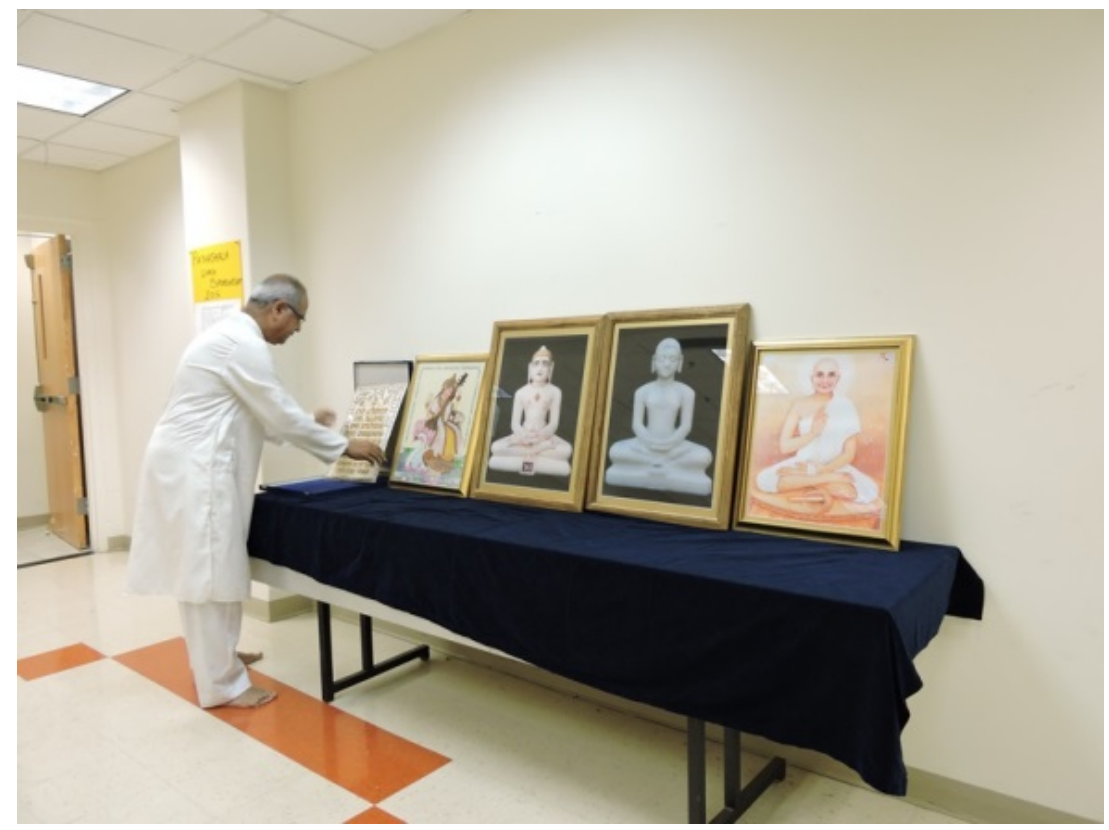

Figure 43. A pāthaśála teacher, places multi-sectarian visuals to elaborate the importance of unity through teaching at pāthaśälä, Jain Society of Metropolitan Chicago 


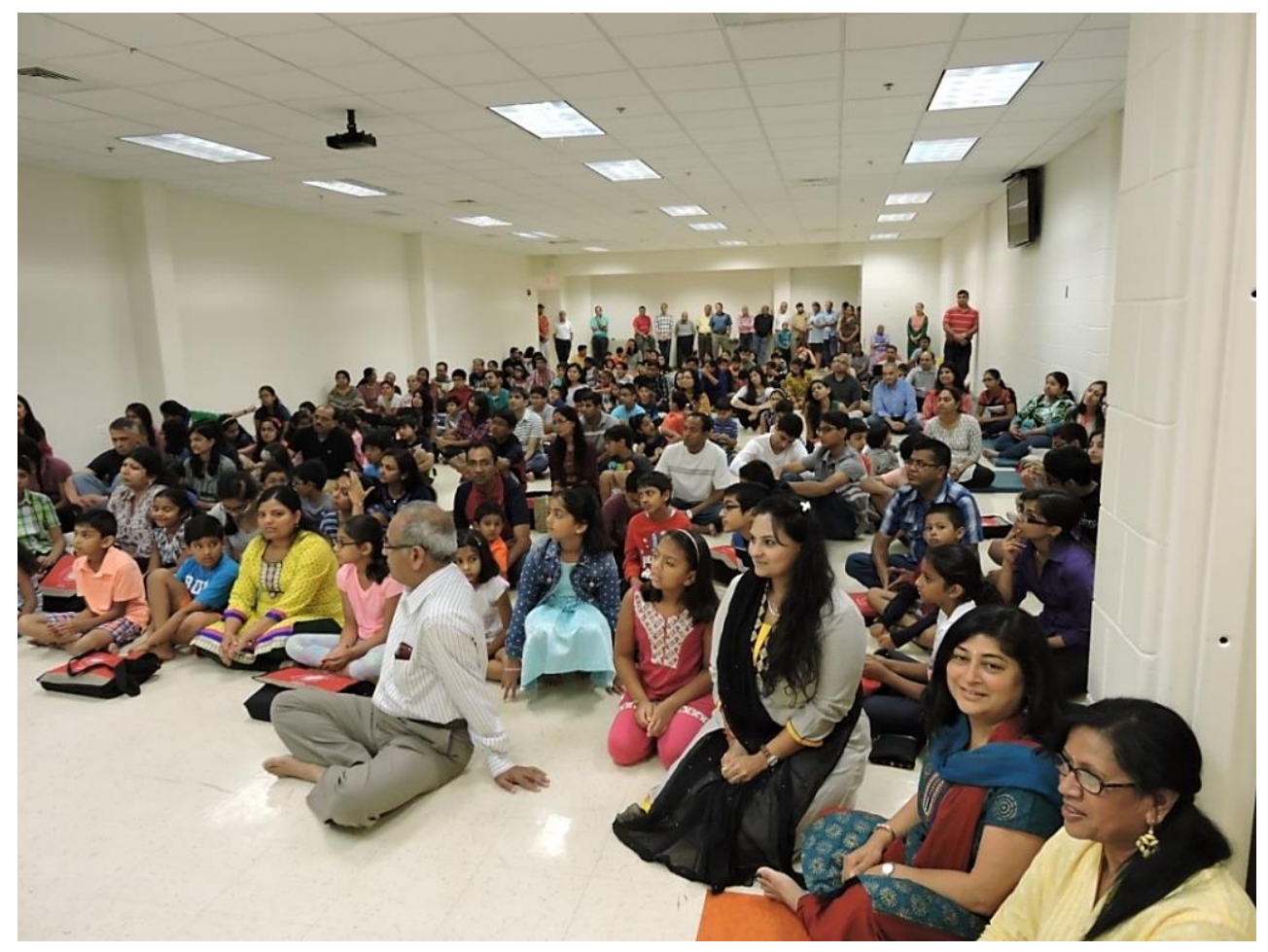

Figure 44. A common orientation session of all-level pāthaśālā classes at the Jain Society of Metropolitan Chicago, (I attended this class!)

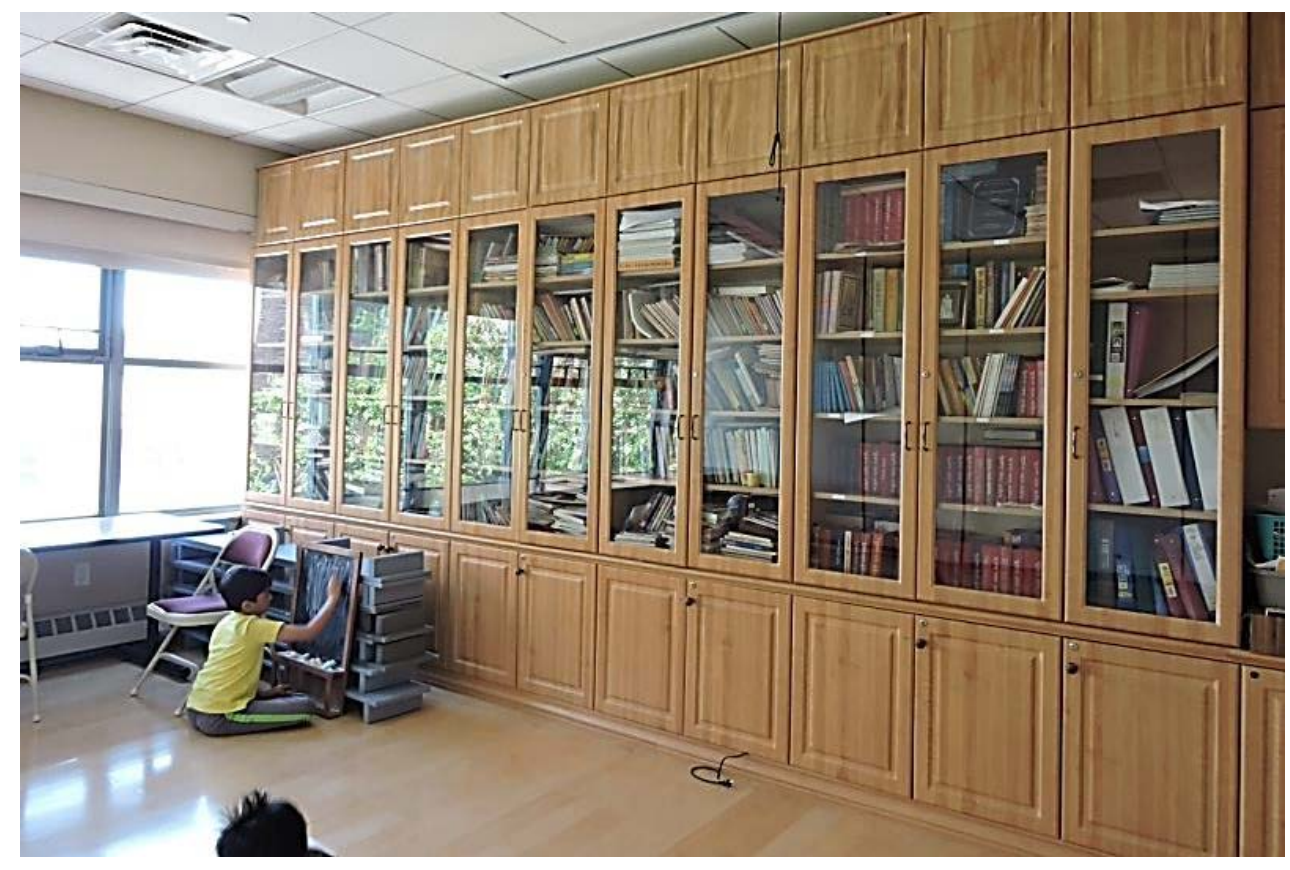

Figure 45. Library section, pāthaśālā room at the Jain Center of America 


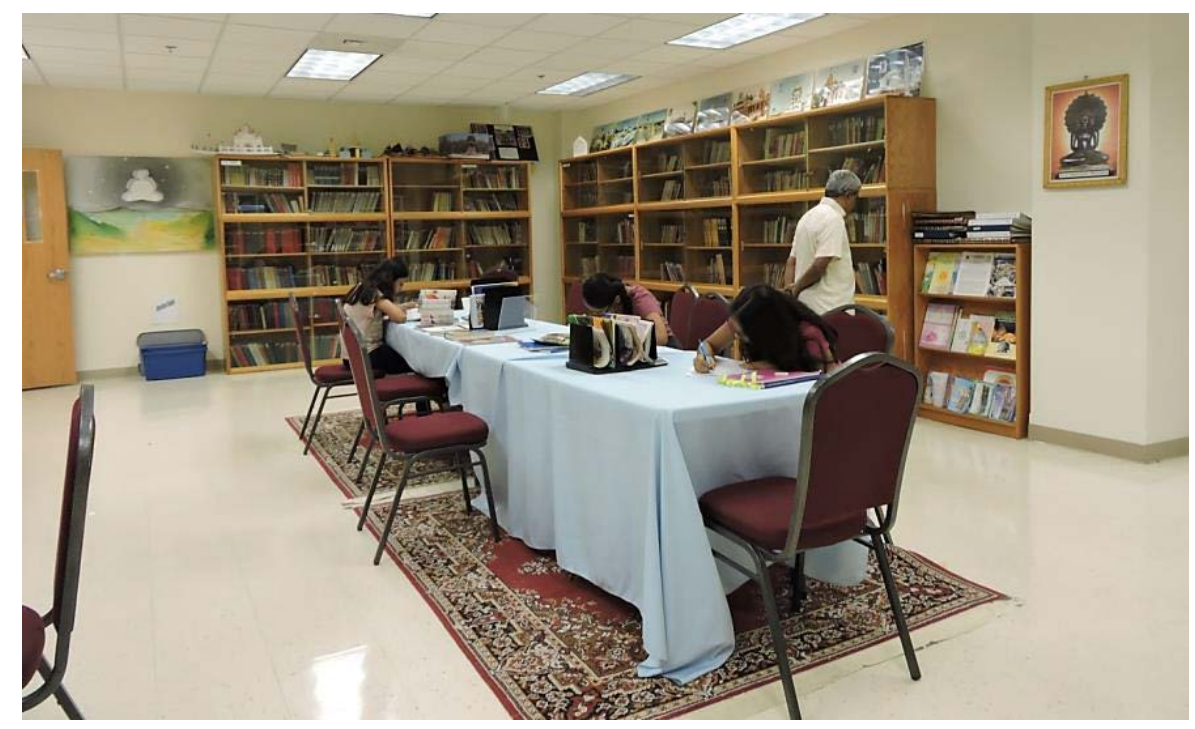

Figure 46. Library, Jain Society of Metropolitan Chicago

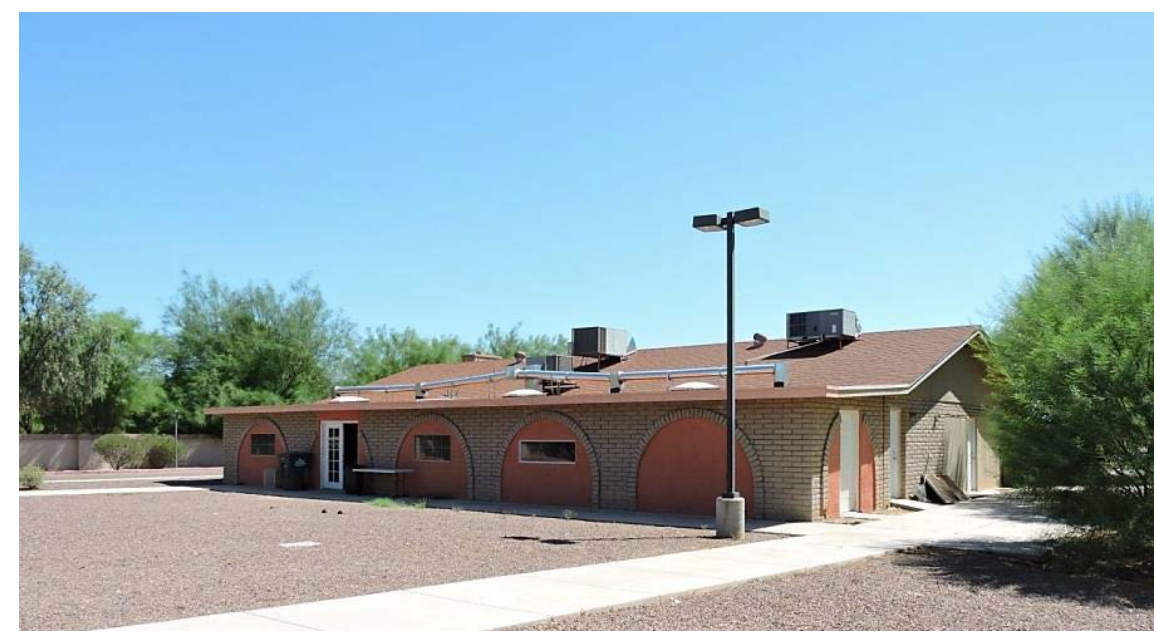

Figure 47. Pāthaśâlā building in the temple compound of the Jain Center of Greater Phoenix

Invention of new form of Jainism: "Mahāvīra never said he was a Śvetāmbara or a

\section{Digambara”}

I argue that the diaspora Jains in the USA have established a common Jain community through practicing the sectarian negotiations among the diversity of Jain traditions.

Following the negotiations, the Jains have created a common Jain identity in the diasporic 
settings. By breaking down the sectarian barriers, the Jains have invented traditions by constructing temples that all the Jain sects share. This also includes invention of ritualvisual cultures by developing all-inclusive, hybrid and syncretic versions of ritual and visual arraignments at the Jain centers (temples). The Jains in the USA integrated as religious minority community in various cities of North America have managed to cease the doctrinal splits of Jainism through adopting different methods and approaches at individual and collective levels. Yet, the Jains did not stop but continued to work towards strengthening the unity at the religious level by introspecting upon the doctrinal and philosophical variety that exist within Jainism. I argue that the sectarian unity among the Jains in the USA contradicts sharply with the sectarian splits that define Jainism in India. Moreover, the Jains in the USA have visualized and invented a new form of Jainism that amended the different sectarian influences. This means, for the Jains, the new form of Jainism identifies for the sectarian unity and not for the sectarian divisions. In doing so, I argue that the Jains, as a dovetailed community have invented a new form of Jainism. They scrutinized carefully what form of Jainism would fit best their needs of the sectarian negotiations; moreover, what kind of meaning of Jainism can become a hallmark of their sectarian negotiations. I will present the attributes of the new form of Jainism, invented by the diaspora Jains in the USA, in the discussion that follows.

In order to demonstrate the new form of Jainism, invented by the diaspora Jains in the USA, I argue that the Jains reflect on what is essential in a Jain tradition in diasporic conditions. The Jains conscious refutation for affiliating Jainism with any doctrinal disputes and the sectarian unity have prompted the Jains to assess what is essential and 
what is not for their version of Jainism in their diasporic context. I use Williams (1984) comments to support my argument:

The critical assumption here is that there are some aspects associated with past religious practice that are fundamental and essential to the continuation of the religion and others that are cultural accoutrements that are not so fundamental. Thus, the process of searching for an adaptive strategy becomes the attempt to distinguish what is essential in the religion and what is not (191).

I argue that based on my observations and responses by the Jains I interviewed during my fieldwork that the religious players were consciously flawless in their understanding of what is essential to the new form of Jainism in the USA. Moreover, this 'invention' at the religious level by the diaspora Jains in the USA is a typical reflection of diaspora as type of consciousness. According to Vertovec (2000), diaspora as type of consciousness occurs through a particular kind of self-questioning stimulated by conditions of ‘diaspora’ coupled with religious pluralism. Under such conditions, believers are often compelled to realize that the routine habitual practice, rote learning and 'blind faith' underpinning previous contexts (where their faith may have been homogeneous or hegemonic) are no longer operational.

The 'invented tradition', the Jain diasporic phenomena is producing from the 'sectarian negotiations' reflects a merging of these two concepts: diaspora as a social form and a type of coconsciousness. While, the concept of diaspora as a social form speaks to the 'sectarian negotiations', the concept of diaspora as type of consciousness appropriately engages the invention of a new form of Jainism. My point here is that the dynamism that made possible the creation of a new form of Jainism is informed by the self-realization of the diasporic conditions of the Jains in the USA. 
As soon as the Jain diaspora community acknowledged its status as a religious minority, as a community marginalized by the larger Indian diaspora, the Jain diaspora realized that to survive in the USA, it has to overlook the doctrinal barriers. To discuss such a shift in a religious self-consciousness, we can also reflect on Geertz's (1971) assertion that there are situations in which the primary question in religious practice shifts from "What shall I believe” to "How shall I believe it?” He argues that this shift entails further, 'a distinction between "religiousness" and "religious mindedness," between being held by religious convictions and holding them.' He notes how the believer may now be in a position to rationalize and justify elements of belief and practice to members of other faiths (61). Applying Geertz's ideas to the development of a 'religious diaspora consciousness' among the Jain diaspora community in the USA, I argue that the goal was to rationalize and justify the consciousness to create a new vision of Jainism through reconsidering the form of Jainism, traditionally accepted for centuries.

"How do you describe the Jainism in the USA for you and your fellow community members?” I asked this question to a Jain male from Phoenix who I spoke with for two hours during the community lunch. He replied "Ours is a generic Jainism". This conversation opens the window to my discussion in this section on what is the nature and attributes of the invented Jainism in the diasporic settings by the Jains in the USA. I will discuss my observations and evaluate how the Jains in the USA have formed a new meaning of Jainism. In continuation with the fact that the Jains on the land of settlement have joined hands at the sectarian level, they have also invented a new image of Jainism. I use the social constructionist approach (Beckford 2003) to uncover the diaspora Jain community members' conceptualization of the new form of Jainism. I 
argue that the global forces such as displacement, diaspora, and quest for creating a common Jain identity at the social level shapes what counts as Jainism for Jains in the USA. In the light of the social coherence, the Jains' invention of a new form of Jainism is deeply persuaded and hence, altered as a result of their sectarian negotiations. However, the Jains, fittingly unconfused by the doctrinal differences and splits accept the version of Jainism that is, completely underlined by the sectarian unity. The Jains in the USA reject the rigid boundaries of canonical and doctrinal dissimilarities within Jainism.

I argue that the Jains adopt the core philosophies, principles and ethics of Jainism but strongly discard the schism based Jain tradition as religion. They mark clear boundaries between what is 'sacred' and 'spiritual' of Jainism. As I interviewed many Jains to explain the new form of Jainism, the answers I received demonstrate what for the Jains is more important to focus in order to explain the meaning of the invented Jainism. It is apparent that the Jains in the USA want a Jainism, which is neutral for the matters that involve sectarian and doctrinal splits. A new form of Jainism is also described by the Jains I interviewed through various expressions such as: "Participation above principles”; “Togetherness matters, doctrines do not matter.”; “We are concerned about "Jainism as a way of life - way of living together"; and "A real meaning of Jainism is reflected through the unity presents here (USA)." I used the direct quotes to demonstrate how the Jains construct the new form of Jainism.

"Rather than divisions, learn the core philosophy" says a young Jain community member and points out to the importance of the sectarian negotiations for explaining what Jainism meant for them as a community. I contend that in conceptualizing a new 
form of Jainism, the Jains in the USA consider emphasizing only the core philosophies of Jainism to be normative. These processes of the negotiation and the creation of a new Jain form reflect commonplace concepts in anthropology such as anti-essentialist, constructivist, and processual approaches to ethnicity (Vertovec 2000 and Baumann \& Sunier 1995). I place emphasis on my observations of the diaspora Jains in the USA by arguing that the Jains are demonstrating anti-essentialist approach by inventing this new form of Jainism.

The new form of Jainism, the Jain migrants have 'invented' in the USA is a blend of two aspects: the first aspect is multi-sectarian or inter-sectarian; and the second aspect is what I term "asectarian." ${ }^{29}$ For the first aspect, the diaspora Jains describe their new form of Jainism that entails acceptance of the fact that Jain tradition is a multisectarian or inter-sectarian. However, this aspect of the new form of Jainism entails the acceptance of the sectarian diversity only at the levels of ritual-visual culture. The second aspect of the invented Jainism includes normative convictions of the Jains in the USA, which rejects to uphold and continue the sectarian doctrinal differences of Jain tradition. I argue that for the Jains in the USA, their new form of Jainism is largely the ‘asectarian’ form of Jainism.

The invented Jain tradition by the US diaspora Jains has multi-layered segments. This includes the sectarian negotiations, creation of a new common, formal Jain community, a common ‘Jain’ identity, invention of multi-sectarian temples and ritual-

\footnotetext{
${ }^{29}$ I term and use the word "asectarian" to define a concept or attitude that is not influenced by any specific sectarian features or characteristics of Jain tradition. I use the term "asectarian" to describe the new form of Jainism invented by the diaspora Jains in the USA, which is not created by affiliating it to any specific sectarian doctrinal school of thoughts. Moreover, I use the term "asectarian" to define the new form of Jainism, invented by the Jains in the USA which is created corresponding to those of the Jaina philosophies that fit to the Jains' condition of the negotiations and a common Jain identity in the USA.
} 
visual cultures. Moreover, the invented Jainism is the 'asectarian’ Jainism pertaining to the doctrinal and philosophical matters. This ‘asectarian' version of Jainism is not influenced by, or centered on any specific sectarian doctrines or philosophy. The invented form of Jainism, which holds ‘asectarian’ attitude is normative for the Jains in the USA because this new form of Jainism does not select any sect-specific doctrinal thoughts to be qualified as a religious tradition. This does not mean that the diaspora Jains in the USA do not wish to "go non-religious", but they intend to be identified as "religious mindedness” (Geertz 1971: 61) by inventing and practicing the multi-sectarian, intersectarian and 'asectarian' Jainism, the invented tradition. I argue that the new form of Jainism corresponds to the idea of religious mindedness.

I argue that the new form of Jainism demonstrates a shift from what Geertz (ibid.) defines as “religiousness” to “religious mindedness”. I now present more aspects about the ways the Jains in their religious diasporic context have invented the new form and meaning of Jainism. I interpret the Jains’ acceptance of Jainism with the inter-sectarian and multi-sectarians understanding still retain certain element of religiousness. However, the creation of new form of 'asectarian' Jainism resembles to the idea of religious mindedness. As I evaluate the new form of Jainism as ‘asectarian’ Jainism, I do not intend to argue that the new form of Jainism is non-doctrinal or empty with any Jain philosophical ideas. The ‘asectarian’ Jainism is a form of religious mindedness Jainism that accepts the core and essential philosophies of Jainism for comfortably apply to all the sects and sub-sects; and additionally, which help to strengthen the unity among the Jains in the USA. 
Rather than making the sectarian doctrinal features as identity of this US diasporic version of Jainism, the Jains in the North America have preferred to authorize this new form of Jainism with the core philosophies of Jaina tradition. The invented Jainism practiced by the Jains in a shared community is conceptualized by non-affiliating it with any Jain sect or any sect-specific interpretation of the doctrinal thoughts. The Jains negate associating the new vision of Jainism with any traditional scriptural interpretations. I argue that instead of instilling Jainism with the doctrinal differences, the Jains in the USA prefer to interlard invented Jainism with the core Jaina philosophies such as ahims $\bar{a}$, anekāntavāda, right-knowledge, right-worldview, and right conducts.

There is one other interesting attribution of the new form of Jainism invented by the Jains residing in the land of settlement. The Jains here in the USA situate themselves as affiliated to 'asectarain' version of Jainism by referring to Mahāvīra. As I interpret the interviews I conducted of the Jain community members, I argue the 'asectarian', new form of Jainism invented by the Jains in the USA is conferred by referring to the Mahāvīra's standing as a non-sectarian. Many Jains pointed out that Mahāvīra never said that he belonged to the Śvetāmbara sect or the Digambara sect. By referring to this, the Jain community members in the USA rationalize the authenticity of their invented form of Jainism. They identify with the Jainism that existed earlier than the schism, divisions and conflicts occurred in the history of Jainism. Moreover, the Jains assert that the form of Jainism, which they have invented and adopted, is the authentic Jainism since it eliminates sectarian division and conflicts but retain only the core philosophies and values. 
'Pizza Effect': the USA Diaspora Jains' Aspiration to Re-import the Invented form of Jainism to India

An anthropologist, Agehananda Bharati (1970: 272), coined the phrase, "Pizza Effect" in the 1970s. Bharti describes the term pizza-effect in terms of "a process of reenculturation” (1970: 273). Further, he explains the term as "synchronic and diachronic study of diffusing and re-entering cultural packets” (1980: 246). The term "Pizza Effect” explains the process of change, re-consideration, and creation of practices under new influences, and their importation back to the place of the actors origin. In terms of its applicability to religious forms, through his pizza-effect theory, Bharti describes a “sociologically predictable route” which involves a redefinition of religious methods, but which does not challenge basic religious values, and which, as a general rule re-considers an attitude and concept (1970: 272). The US diaspora Jains have expressed a desire to reimport and introduce their version of invented Jainism to Indian Jains, a move that reflects Bharti’s (1970) pizza-effect concept. I have argued in the chapters of this study that the Jains in the USA have re-considered the social and religious aspects of the Jain tradition, and have initiated sectarian negotiations and in the process, invented a new form of Jainism. In this connection, I see the US diaspora Jains are assertive on introducing their invented tradition to Indian Jain communities.

During my interactions with the Jains in the USA, they expressed an awareness of the conflicts and disagreements that are typical of the Jains in India at the social, cultural and religious levels. Most of my interviews with first- and second- generation diaspora Jains who either migrated from India or from the other parts of the world to the USA suggested that Jains in India should follow this model of the sectarian negotiation and 
‘asectarian’ version of Jainism. Many Jain community members stated firmly in the interview that "Here, it is not like India." ${ }^{30}$ Moreover, most of my interviews with the Jains in the USA ended with them suggesting, "This kind of negotiations and new form of Jainism should be practiced by Jains in India.” In some interviews, the Jains stressed upon having different identity than those of Jains in India. Although, the Jains in the USA still have affection and attachment to their motherland, they prefer to be identified with their common Jain identity that incorporates the negotiations and new form of Jainism. This entails their opinion that the Jains in India are still busy maintaining their sectarian affiliation and practice Jainism accordingly, which the Jains in the USA see as an obstacle for social and religious unity. For the Jains in the USA, the formation of a common Jain identity has been a successful effort because of their re-configuring of the Jain culture. With this reference, the Jains in the USA fluently convey that Indian Jains should follow their invented form of Jainism.

\section{Conclusion}

Will changing what Jainism means in the diasporic context take away the faith the Jain immigrants have in their tradition? If religion is shaped to a new form, and it helps to fulfill the needs of a group in their social and spiritual world, then is it not an adequate adoption of a religion? I argue that for the Jains in the USA, the diaspora condition is the main reason for which they have formed and shaped their traditions in a new version.

All of the four Jain communities in the USA I studied are minority communities and constitute a segment of the larger Indian diaspora. However, the Jains have constructed their negotiation in the orbit of their religion- Jainism and have succeeded in

\footnotetext{
${ }^{30}$ They referred to the sectarian disputes within the Jain tradition; and also the barriers based on other identity markers on social, religious and cultural levels.
} 
meeting the desired result for their social, cultural and religious need. All inclusive and yet not governed by any sectarian tradition, the invented Jainism is a well-thought, wellperceived, well-organized and well-received Jainism for the diaspora Jains in the USA. I have tried to articulate the positive aspects of the sectarian negotiations and invention of a new form of Jainism at various levels that Jains in the USA demonstrated. In finding these constructive aspects of the Jains in the USA, I am all the more enthusiastic about their future inventions at the social and religious spheres. If this thesis teaches us anything at all about the interplay between diaspora, religion, and people, it is the fact that nothing can dissipate a group if it relinquishes rigidity, bias and intolerance. 


\section{CONCLUSION}

In this very brief chapter, I will tie together the strands of the arguments that run through the chapters of this study. I have sought to answer the following questions in this study. What distinguishes the Jain diaspora community in the USA aside from being displaced

or de -territorialized? How are the Jains in the USA responding to the diversity of the Jain tradition-culture and to their status as a religious minority in a diasporic environment? How do attempts to respond to their religious and socio cultural needs translate into their inventing of a new Jain tradition? In addition, what are the features of this new Jainism? In response to these questions, I have argued, based on my ethnographic research of four Jain communities in the USA, that a distinguishing feature of diaspora Jainism in the USA the process of sectarian negotiations. These negotiations represent efforts of Jains in the USA to overlook the sectarian differences that have typically divided Jains in India, in a bid to construct a Jain religion to which all Jains in the diaspora can relate easily. The ultimate goal of this project is to foster a sense of unity among Jains in the American diaspora and to provide for subsequent generations a solid ground on which to construct and perform a Jain identity in the USA. In this connection one of the theoretical contributions of the study is the idea that ethnicity is not fixed thing but a process, and that Jains in the USA are in the process of inventing a new form of Jainism as the basis of a new Indian ethnicity in the USA. Jains from India, the homeland, and from places such as Africa are coming together to constitute this new Jain ethnicity. A related theoretical contribution is the idea that diaspora can foster the creation of new ethnicities as groups seek answers to emerging questions and religion can be used as the focus of these projects. 
The study explored the levels on which the negotiations in the Jain temples are unfolding; the ritual-visual culture and the doctrinal and philosophical discourses. The negotiations at the doctrinal and philosophical, which involve an exclusive emphasis on core and shared beliefs of Jainism, and a de-emphasis on contestations, provide ideological support or rationalization for the negotiations occurring on the ritual-visual culture levels.

This study represents the application of the concept of the invention of the tradition, which scholars typically use to analyze socio-political processes, to a specific religious context, which is the Jain religious diaspora in the USA. In this way, the study contributes to our understanding of the dynamics of inventing of traditions in religious contexts, specifically, among religious minorities in diasporas such as the Jains in the USA. We see that the process is extremely complex as the actors involved have a diversity of Jain identities; they are from different sects, some migrated directly from India, others are Indians involved in a secondary migration from places such as Africa and Australia, and they have varying caste (jāti/jñäti), linguistic and cultural backgrounds. The study offers us the opportunity to explore how disparate groups with different social and religious identities can meet and use their diverse resources to invent a new tradition.

The study shows how the diaspora can make groups rethink their traditional practices and reform them in ways they may not do in the homeland. Sects of Jainism in India still do not welcome the idea of their members participating in common Jain religious practices. Sociologically it is not typical to see members of the different sects interacting. It will be profitable to investigate whether this diasporic development has any 
impact on Jain practices and thinking in India and how. Can this diasporic model of Jainism shape the future of Jainism as a religion in India? Moreover, the research on the diaspora Jains in USA also demonstrates a trajectory that departs somewhat from a pattern that is typical among diasporic communities. Diasporic communities often establish transnational links with the homeland and many of them use religion as a channel. The Jains of the USA studied in this research do not seem to fall in this category. The invented diasporic Jainism seems to depart so much from Jainism in India that there seems to be not yet a basis for a linkage between them. The key findings from this research on Jain migrant religion and its dynamics raise questions for future research. One question I have not adequately explored and will like to investigate further is the gendered dimension of the sectarian negotiations experience. Do male and female members of the Jain community in the USA view the negotiations in the same way? Related to this is the question of how the sectarian negotiations affects the members' attitudes towards choosing marriage partners? Are members of different sects more willing to marry across their own sects now than before? How are contemporary changes in migration policies in the USA affecting Jain migrant religion? For example, the current anti migration stance of some people in the USA has engendered a sense of insecurity among migrants -what will be the impact on the Jain quest for unity and identity. 


\section{REFERENCES}

Acharang-Bhasyam. 2001. Edited by Ācārya Mahaprajñā, with Vāchanā Pramukh Gandhipati Tulsi, English Rendering by Nathmal Tatia, Muni Dulaharj, Muni Mahendra Kumar. Ladnun: Jain Vishva Bharti.

Appadurai, Arjun. 1996. Modernity at Large: Cultural Dimensions of Globalization. Minneapolis, MN: University of Minnesota Press.

Babb, L. 1996. Absent Lord: Ascetics and Kings in a Jain Ritual Culture. University of California Press: Berkley.

Banks, J. A. 1972. The Sociology of Social Movements. London: Macmillan.

Banks, Marcus. 1992. Organizing Jainism in India and England. Oxford: Clarendon Press.

- 2000. "Views of Jain history." In Anthropologists in a Wider World: Essays on Field Research, edited by Paul Dresch, Wendy James and David Parkin, 187-204. Berghahn Books: Oxford.

Baumann, Gerd, and Thijl Sunier. 1995. Post-Migration Ethnicity: De-Essentializing Cohesion, Commitments, and Comparison. Amsterdam: Het Spinhuis Publishers.

Baumann, Martin. 1995. "Conceptualizing Diaspora: The Preservation of Religious Identity in Foreign Parts, Exemplified by Hindu Communities Outside India.” Temenos 31:19-35.

Beckford, James A. 2003. Social Theory and Religion. Cambridge, U.K.: Cambridge University Press.

— . 2000. "Religious Movements and globalization.” In R. Cohen and S. Rai eds., Global Social Movements, 165-83. London: Athlone.

Berger, Peter L., and Thomas Luckmann. 1966. The Social Construction of Reality: A Treatise in The Sociology Of Knowledge. Garden City, NY: Doubleday.

Beyer, Peter. 1994. Religion and Globalization. London: Sage.

Bhabha, Homi. 1994. The Location of Culture. New York: Routledge.

Bharati, Agehandanda. 1970. "The Hindu Renaissance and its Apologetic Patterns.” Journal of Asian Studies, 29 No. 2: 267-287. dio:102307/29422625. 
—. 1976. "Ritualistic Tolerance and Ideological Rigour: The Paradigm of the Expatriate Hindus in East Africa." Contributions to Indian Sociology 10, 2: 317339. 10.1177/006996677601000206.

—. 1980. "Indian Expatriates in North America and Neo-Hindu Movements." In J. S. Yadava, and Vinayshil Gautam eds,. The Communication of ideas. New Delhi: Concept. 245-270.

Bhattacharya, B.C. 1971. The Jaina Iconography. New Delhi: Motilal Banarasidas.

Bhattacharyya, A. K. 2010. Historical Development of Jaina Iconography: A Comprehensive Study. Delhi: Bharatiya Kala Prakashan.

Bruce, Steve. 1999. Choice and Religion: A Critique of Rational Choice Theory. New York: Oxford University Press.

Cannnadine, David. 1983. "The Context, Performance and Meaning of Ritual: The British Monarchy and the 'Invention of Tradition', c. 1820-1977.” In E. J. Hobsbawm and T. O. Ranger eds.,Invention of Tradition , 101-64. Cambridge: Cambridge University Press.

Carrithers, M. 1988. "Passions of Nation and Community in the Bahubali Affair." Modern Asian Studies, vol. 22, part 4, 815-44.

Carspecken, Phil Francis. 1996. Critical Ethnography in Educational Research; A Theoretical and Practical Guide. New York and London: Routledge.

Clifford, James. 1992. "Traveling Cultures.” In L. Grossberg, C Nelson and P.A. Treichler eds., Cultural Studies, 96-116. New York: Routledge.

—. 1994. "Diasporas.” Cultural Anthropology 9, no. 3: 302-38. doi:10.1525/can.1994.9.3.02a00040.

Cohen, Robin. 2008. Global Diaspora: An Introduction. New York: Routledge.

Cort, John E. 1998. Open Boundaries: Jain Communities and Culture in Indian History. Albany, NY: State University of New York Press.

—. 2001. Jains in the World: Religious Values and Ideology in India. Oxford: Oxford University Press.

—. 2010. Framing the Jina: Narratives of Icons and Idols in Jain History. Oxford: Oxford University Press. 
Creswell, J. W. 2013. Qualitative Inquiry and Research Design: Choosing among Five Approaches. Los Angeles, CA: Sage.

DeWalt, Kathleen M, and DeWalt, Billie R. 2002. Participant Observation: A Guide for Fieldworkers. Walnut Creek, CA: AltaMira Press.

Dewey, John. 2013. A Common Faith. New Haven: Yale University Press, 2013.

Dhaky M.A. 1997. Arhat Pārśva and Dharnedra Nexus. Ahmedabad: Lalbhai Dalpatbhai Institute of Indology.

Dixit, K. K. 1978. Early Jainism. Ahmedabad: L. D. Institute of Indology.

Dundas, Paul. 1985. “Food and Freedom.” Religion 15, no. 2: 161-97. doi:10.1016/s0048-721x(85)80009-9.

—. 2002. The Jains. Routledge: London.

Durkheim, Émile. 1995. The Elementary Forms of Religious Life. Trans. Karen E. Fields. New York: The Free Press.

Eck, Diana, L.1981. Darśan: Seeing the Divine Image in India. Chambersburg, PA: Anima Books.

—. 2000. "Negotiating the Hindu Identities in America." In The South Asian Religious Diaspora in Britain, Canada, and the United States, edited by Coward, Harold, John R. Hinnells, and Raymond Brady Williams, 219-238. Albany, NY: State University of New York Press.

Evans, Brett. 2012. "Jainism’s Intersection with Contemporary Ethical Movements: An Ethnographic Examination of a Diaspora Jain Community." The Journal of Undergraduate Ethnography 2, no. 2: 1-12.

Fischer, E . and J. Jain. 1977. Art and Rituals: 2500 Years of Jainism in India. New Delhi: Sterling Publishers.

Flügel, Peter. 2006. Studies in Jaina History and Culture: Disputes and Dialogues. London: Routledge.

— . 2012. "Jainism.” In Encyclopedia of Global Studies, edited by Helmut K. Anheier and Mark Juergensmeyer, 1000-979. Thousand Oaks, CA: SAGE Publications, Inc. doi: 10.4135/9781452218557.n308.

Fohr, Sherry. 2015. Jainism: A Guide for the Perplexed. London: Bloomsbury Academic. 
Folkert, Kendall W.1993. Scripture and Community: Collected Essays on the Jains. Atlanta, GA: Scholars Press.

Foote, M. Q., \& Bartell, T. G. 2011. "Pathways to Equity In Mathematics Education: How Life Experiences Impact Researcher Positionality.” Educational Studies in Mathematics, 78, 45-68.

Geertz, Clifford. 1971. Islam Observed: Religious Development in Morocco and Indonesia. Chicago: University of Chicago Press.

—. 1973. The Interpretation of Cultures: Selected Essays. New York: Basic Books.

Gopalan, S. 1973. Outlines of Jainism. New York: Halsted Press.

Gould, Jeremy. 2004. "Positionality and Scale: Methodological Issues in the Ethnography of Aid.” In Gould, Jeremy, and Henrik Secher. Marcussen, eds., Ethnographies of Aid: Exploring Development Texts and Encounters. Roskilde, Denmark: Graduate School, International Development Studies, Roskilde University.

Granoff, Phyllis. 2009. Victorious Ones: Jain Images of Perfection. New York: Rubin Museum of Art.

Griffith, A.I. 1998. "Insider/ Outsider: Epistemological Privilege and Mothering Work.” Human Studies 21: 361-76.

Hall, Stuart. 1990. “Cultural Identity and Diaspora.” In J. Rutherford ed. Identity: Community, Culture, Differences. 222-37. London: Lawrence and Wishart.

Hammersley, Martyn, and Paul, Atkinson. 2007. Ethnography: Principles and Practice. London: Routledge.

Heberle, Rudolf. 1951. Social Movements; An Introduction to Political Sociology. New York: Appleton-Century-Crofts.

Hinnells, John R. 2007. Religious Reconstruction in the South Asian Diasporas: From One Generation to Another. Basingstoke, Hampshire: Palgrave Macmillan.

Hobsbawm, E. J., and T. O. Ranger. 1983. The Invention of Tradition. Cambridge: Cambridge University Press.

Humphrey, Caroline, and James Laidlaw. 1994. The Archetypal Actions of Ritual: A Theory of Ritual Illustrated by the Jain Rite of Worship. Oxford: Clarendon Press.

Hunter, William Wilson. 1887. The Imperial Gazetteer of India. London: Trübner. 
J. Holdaway eds., Immigrant Faiths: Transforming Religious Life in America. 219-242. Lanham, MD: Altamira Press.

Jaini, Padmanabh S. 1991. Gender and Salvation: Jaina Debates on the Spiritual Liberation of Women. Berkeley: University of California Press.

—. 2008. "Jain Sectarian Debates: Jain Sectarian Debates. Eighty-Four Points of Contention (Cauryāṃsi Bol) between Śvetāmbaras and Digambaras (Text and Translation)". Journal of Indian Philosophy Vol. 36, no. 1: 1-246. doi:10.1007/s10781-007-9020-x.

Johnson, P. C. 2012. "Religion and Diaspora." Religion and Society, 3(1), 95-114. doi:http://dx.doi.org.ezproxy.fiu.edu/10.3167/arrs.2012.030106.

Kapadia, H. R. 1947. "Introduction” In Anekāntajayapatā by Haribhadra Süri with His Own Commentary and Municandra Süri's Supercommentary, vol. 2, pp. ixcxxviii. Gaekwad's Oriental Series 105. Baroda: Oriental Institute.

Kelting, Mary Whitney. 2001. Singing to the Jinas: Jain Laywomen, Mandal Singing, and the Negotiations of Jain Devotion. Oxford: Oxford University Press.

Kotin, Igor. 2006. "Religious Pluralism in London: Ethnicity, Religion and Caste Among Indians in Southall (Middx, UK).” In In Religious Pluralism in the Diaspora, edited by P. Pratap Kumar, 175-188. Leiden: Brill.

Kumar, P. Pratap. 2006. Religious Pluralism in the Diaspora. Leiden: Brill.

Kymlicka, W. 1995. Multicultural Citizenship. Oxford: Clarendon Press.

Laidlaw, James. 2010. "Ethical Traditions in Question: Diaspora Jainism and the Environmental and Animal Liberation Movements.” In Ethical Life in South Asia, edited by Anand Pandian and Daud Ali, 61-80. Bloomington: Indiana University Press.

Lambek, Michael. A Reader in The Anthropology Of Religion. Malden, MA: Blackwell Publishers, 2002.

Lee, Jonathan H. X. 2010. Encyclopedia of Asian American Folklore and Folklife. ABCCLIO.

Leonard, Karen Isaksen. 2005. Immigrant Faiths: Transforming Religious Life in America. Walnut Creek, CA: AltaMira Press.

Levitt, Peggy. 2003. “'You Know, Abraham was really the First Immigrant’: Religion and Transnational Migration.” International Migration Review, 37(3), 847-873. 
London and Toronto. Toronto: University of Toronto Press.

Long, Jeffery D. 2009. Jainism : An Introduction. London \& New York : I.B. Tauris.

Madison, D. S. 2012. Critical Ethnography: Method, Ethics, and Performance (2nd ed.). Thousand Oaks, CA: SAGE.

Mahāprajña, Ācārya. 2010. Anekānta: Philosophy of Co-existence. Ladnun: Jain Vishva Bharti.

Mardia, K.V., and Rankin, A.D. 2013. Living Jainism: An Ethical Science. Hants: Mantra Publication.

Marshall, Catherine \& Rossman, Gretchen B. 1989. Designing Qualitative Research. Newbury Park, CA: Sage.

Matilal, B. K. 2012. The Central Philosophy of Jainism (Anekātavāda). Ahmedabad: L.D. Institute of Indology.

McCrone, David. 1998. The sociology of Nationalism: Tomorrow's Ancestors. London: Routledge.

Nader, Luara. 2011. “Ethnography as Theory.” Hau: Journal of Ethnographic Theory 1, no. 1: 211-19. doi:10.14318/2fhau.v1i1.

Padmarajiah, Y. J. 1986. A Comparative Study of the Jaina Theories of Reality and Knowledge. Delhi: Motilal Banarasidas.

Reinharz, S. 2011. Observing the Observer: Understanding Ourselves in Field Research. New York, NY: Oxford University Press.

Repstad, Pål. 1996. Religion and Modernity: Modes of Co-existence. Oslo: Scandinavian University Press.

Rukmani, T. S. 2001. Hindu Diaspora: Global Perspectives. New Delhi: Munshiram Manoharlal Publishers.

Salter, Emma. 2006. "Rethinking Religious Authority: A Perspective on the Followers of Śrimad Rājcandra.” In Peter Flügel ed. Studies in Jaina History and Culture: Disputes and Dialogues. London: Routledge. 241-262.

Shah, U.P. 1987. Jaina-Rūpa Manḍala. New Delhi: Shakti Malik.

—. 1998. Studies in Jain Art. Varanasi: Parsvanath Vidhyapith. 
Suffla, Shahnaaz, and Mohamed Seedat. 2014. "Reflexivity, Positionality, Context, and Representation in African And Arab Enactments of Community Psychology.” Journal of Community Psychology 43, no. 1: 4-8. doi:10.1002/jcop.21716.

Sukhalalji, Pandit. 1988. Essence of Jainism. Ahmedabad: L. D. Institute of Indology.

Sultana, Farhana. 2007. "Reflexivity, Positionality and Participatory Ethics: Negotiating Fieldwork Dilemmas in International Research.” ACME: An International EJournal for Critical Geographies, 6(3), 374-385.

Umāsvāti. 1994. Tattvārtha Sütra - 'That Which Is': With the Combined Commentaries of Umāsvāti, Pūjayapāda and Siddhasenagaṇi. Translated by Nathmal Tatia. USA: HaperCollins Publishers.

Vallely, Anne. 2002. "From Liberation to Ecology: Ethical Discourses among Orthodox and Diaspora Jains.” In Jainism and Ecology: Nonviolence in the Web of Life, edited by Christopher Chapple, 193-213. Cambridge: Harvard University Press.

—. 2002. Guardians of the Transcendent: An Ethnography of a Jain Ascetic Community. Toronto: University of Toronto Press.

Vasquez, M. A. 2005. "Historicizing and Materializing the Study of Religion: The Contribution of Migration Studies.” In Immigrant Faiths: Transforming Religious Life in America, edited by Karen I. Leonard, Alex Stepick, Manuel A. Vasquez, and Jennifer Holdaway. Lanham, Md: AltaMira Press. 219-242.

Vasquez, M. A., \& Knott, K. 2014. "Three Dimensions of Religious Place-Making in Diaspora.” Global Networks, 14(3), 326-347. DOI: 10.1111/glob.12062.

Vásquez, M. A., and Marie F. Marquardt. 2003. Globalizing the Sacred: Religion Across the Americas. New Brunswick, NJ: Rutgers University Press.

Vekemans, Tine. 2015. “Transnational Connections and Religious Development in the Jain Diaspora through an Exploration of the E-diaspora." In Discovering Diaspora: A Multidisciplinary Approach, ed. Tine Vekemans and Natasha Miletic, 109-120. Oxford, UK: Inter-Disciplinary Press.

Vertovec, Steven, and Robin Cohen. 1999. Migration, Diasporas, and Transnationalism. Cheltenham, UK: Edward Elgar.

- 1992. Hindu Trinidad: Religion, Ethnicity and Socio-Economic Change. London: Macmillan Carribean.

—. 2000. The Hindu Diaspora: Comparative Patterns. London: Routledge. 
Wach, Joachim. 1962. Sociology and Religion. Chicago: Univ. of Chicago Press.

Wiley, Kristi L. 2006. The A to Z of Jainism. Lanham, MD: Scarecrow Press.

Willford, Andrew. 2002. ““Weapons of the Meek”: Ecstatic Ritualism and Strategic Ecumenism among Tamil Hindus in Malaysia.” Identities 9, no. 2: 247-80. doi:10.1080/10702890212203.

Williams, Raymond B. 1984. A New Face of Hinduism: The Swaminarayan Religion. Cambridge: Cambridge University Press.

Wuaku, Albert Kafui. 2013. Hindu Gods in West Africa: Ghanaian Devotees of Shiva and Krishna. Leiden: Brill. 